\title{
Everybody playing together: West Virginia educators' perspective on the implementation of the universal preschool policy
}

\author{
Ashley Atkins Martucci \\ West Virginia University
}

Follow this and additional works at: https://researchrepository.wvu.edu/etd

\section{Recommended Citation}

Martucci, Ashley Atkins, "Everybody playing together: West Virginia educators' perspective on the implementation of the universal preschool policy" (2009). Graduate Theses, Dissertations, and Problem Reports. 4498.

https://researchrepository.wvu.edu/etd/4498

This Dissertation is protected by copyright and/or related rights. It has been brought to you by the The Research Repository @ WVU with permission from the rights-holder(s). You are free to use this Dissertation in any way that is permitted by the copyright and related rights legislation that applies to your use. For other uses you must obtain permission from the rights-holder(s) directly, unless additional rights are indicated by a Creative Commons license in the record and/ or on the work itself. This Dissertation has been accepted for inclusion in WVU Graduate Theses, Dissertations, and Problem Reports collection by an authorized administrator of The Research Repository @ WVU.

For more information, please contact researchrepository@mail.wvu.edu. 


\title{
Everybody Playing Together:
}

\section{West Virginia Educators' Perspective on the}

\section{Implementation of the Universal Preschool Policy}

\author{
Ashley Atkins Martucci \\ Dissertation submitted to the College of Human Resources and Education \\ at West Virginia University \\ in partial fulfillment of the requirements \\ for the degree of \\ Doctor of Education \\ In \\ Curriculum and Instruction \\ Approved by \\ Joy Faini Saab, Ed.D., Chairperson \\ Sheila Benson, Ph.D. \\ David Callejo, Ed.D. \\ Patricia Obenauf, Ed.D. \\ Jaci Webb-Dempsey, Ph.D. \\ Department of Curriculum \& Instruction/Literacy Studies \\ Morgantown, WV \\ Copyright 2009
}

Key words: early childhood, educational policy 


\begin{abstract}
Everybody Playing Together: West Virginia Educators Perspective on the Implementation of Universal Preschool Policy

Ashley Atkins Martucci
\end{abstract}

This dissertation examines West Virginia’s Universal Access to a Quality Early Education System (Policy 2525) mandate for mandatory universal preschool through a study of the roles of stakeholders in the implementation, understanding, and perspectives about the issues. Thirteen interviews were conducted to gain multiple perspectives of West Virginia educators'. The interviewees included: a state government representative, three early childhood state administrators, three early childhood county administrators, three early childhood local administrators, and three early childhood teachers. The policy provides a framework for the interviews conducted and the language utilized by the interviewees. This discourse and discrepancy analysis unveiled complex perspectives of the participants. Collaboration, ratio, and infrastructure were the key elements that surfaced continually throughout the interviews. These three elements have both positives and negatives associated with them. The policy provides a backdrop for early childhood education to help obtain a common goal in West Virginia. 


\section{Dedication}

I would like to dedicate this to my family Jeff, Braxton, and Grayson; my parents, Bill and Carolyn Atkins; and my sister, Melany Atkins, for their never ending support and guidance. 


\section{Acknowledgements}

To my parents, Bill and Carolyn Atkins, this would have never been possible or even imagined without your guidance, love, support, and encouragement. As always, you believed in me.

To Jeff Martucci, my husband, thank you for the endless days and nights of discussing dissertations, supporting me, and encouraging me. You never second guessed my ability to complete this. To Braxton and Grayson, my son and daughter, thank you for reminding me why this needed to be completed.

To my sister, Melany Atkins, for always keeping me in check and never letting anything become overwhelming.

To my Nunna, Poppa, Mamaw, and Papaw Don, I thank you for paving an educational pathway for me. I miss you all.

I would like to thank Tryon Hills Pre-K Center, in Charlotte, NC, for giving me my first job as a preschool teacher and instilling a love of preschool children, especially to Bonnie Schmidt, the principal and Kim Foxworth, my mentor.

Thank you to my doctoral dissertation committee that provided me guidance and mentoring throughout the entire process. I would like to thank Dr. Joy Saab for continuously encouraging me during the process and providing me endless opportunities. Thank you to Dr. David Callejo for working with me throughout the process and meeting with me for revisions. To Dr. Jaci Webb-Dempsey for meeting with me on her own time to discuss my qualitative work. To Dr. Sheila Benson and Dr. Pat Obenauf for keeping me on track, motivated and focused. 
Last but not least, thank you to Dr. Sarah Selmer for introducing me to numerous ideas and ways to make this process a little easier. 


\section{Table of Contents}

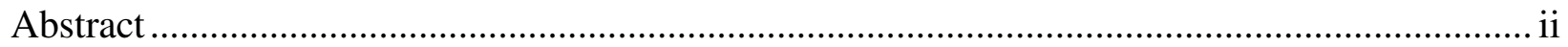

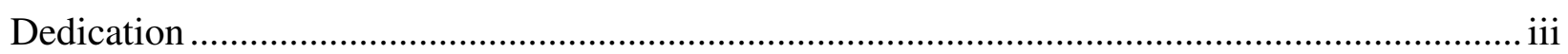

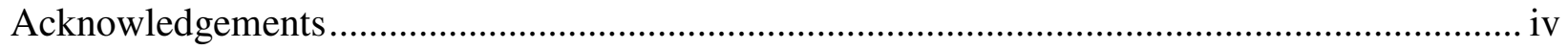

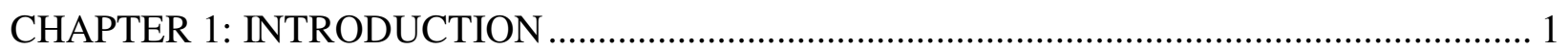

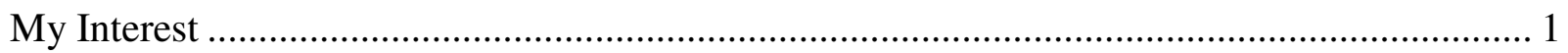

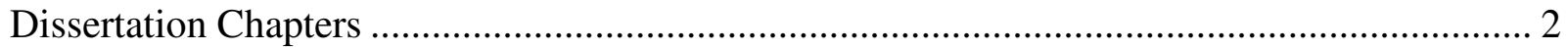

A Broad Influence ................................................................................................ 3

History of EC education from Gesell to HS to Universal Preschool.................................... 4

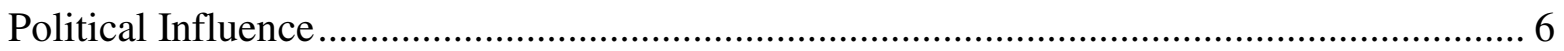

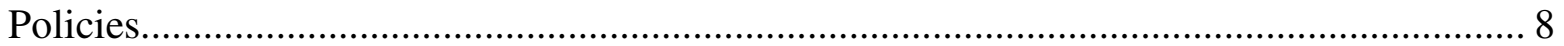

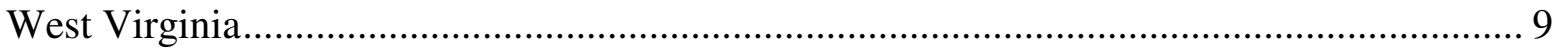

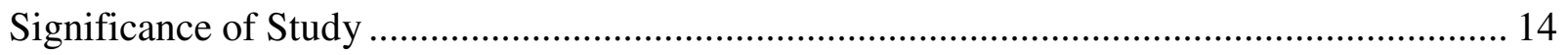

Philosophical approach to early childhood education ................................................. 14

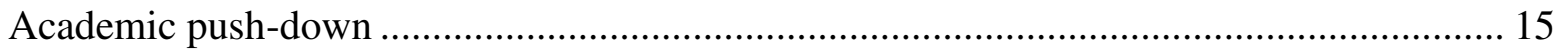

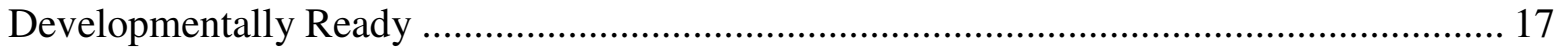

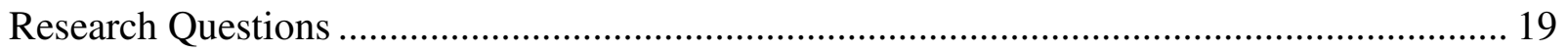

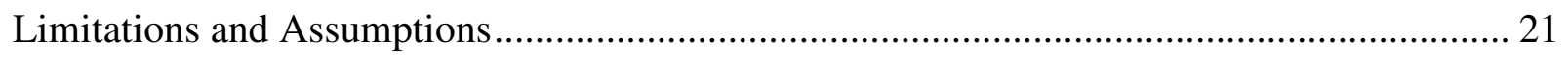

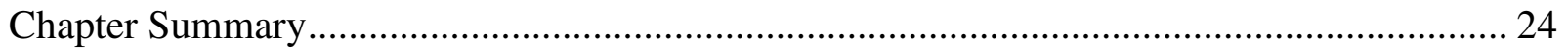

Definitions of Commonly Used Terms …........................................................................ 24

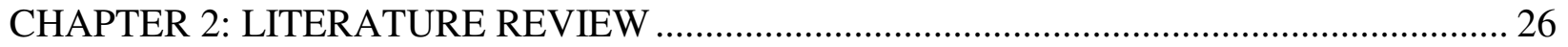




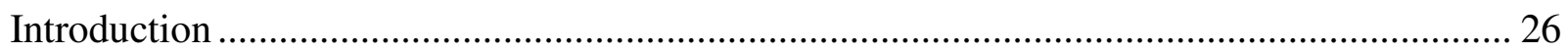

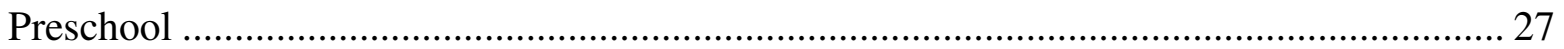

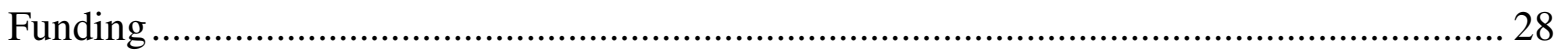

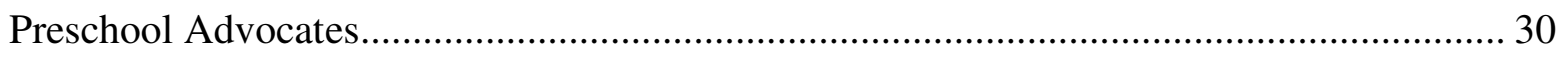

The Global Influence of Philosophers and Educators .............................................................. 32

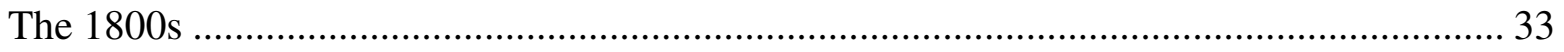

Early Childhood Education in the United States.................................................................... 39

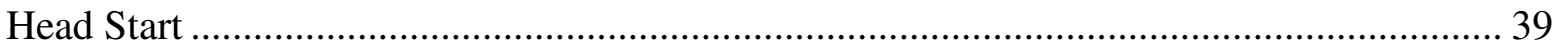

West Virginia’s Universal Access to a Quality Early Education System (2525) Defined.... 43

Why Preschool?

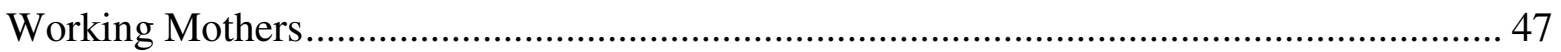

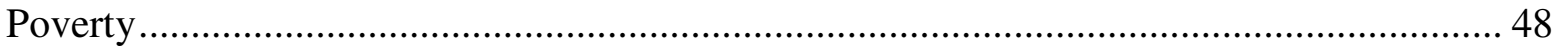

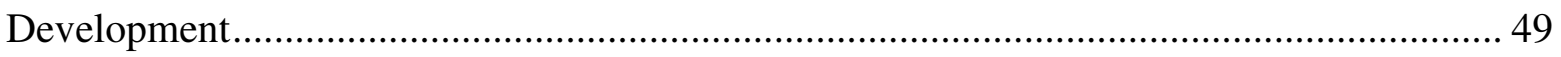

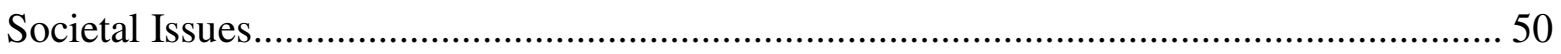

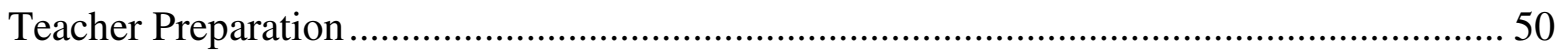

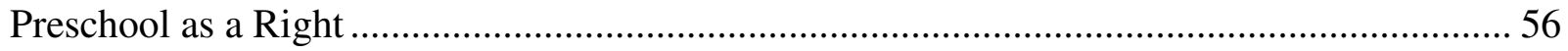

Characteristics of High Quality Preschool Programs................................................................ 57

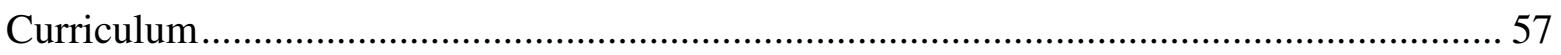

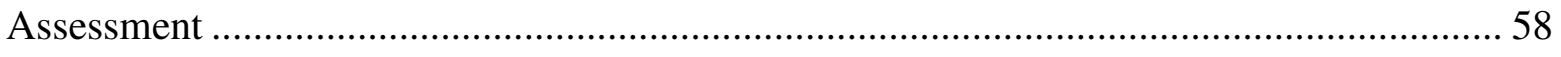

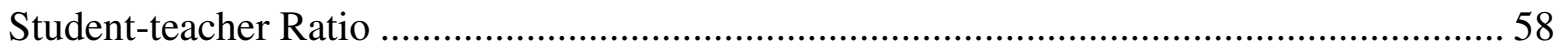




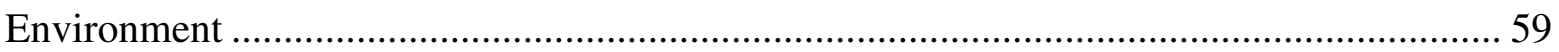

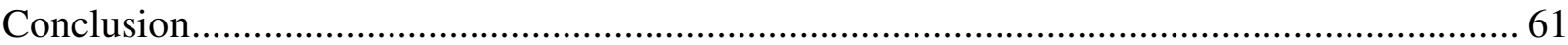

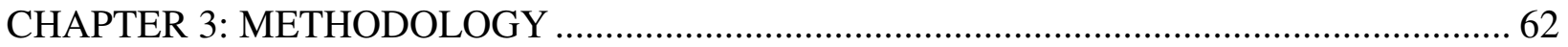

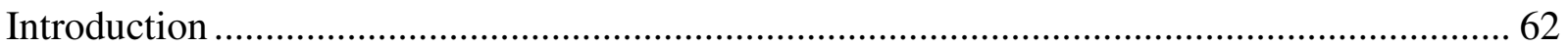

Rationale

Research Questions ............................................................................................................ 65

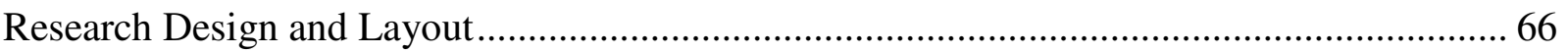

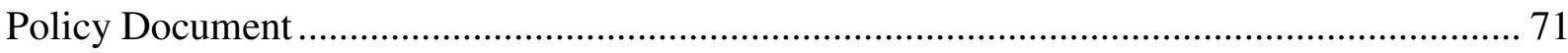

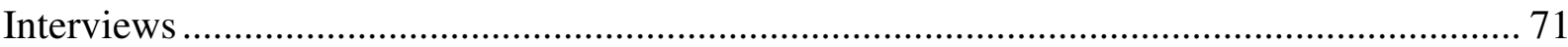

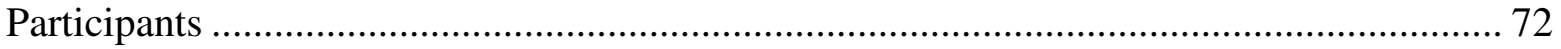

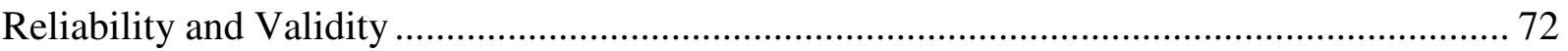

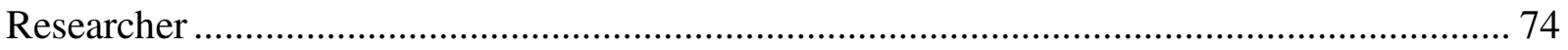

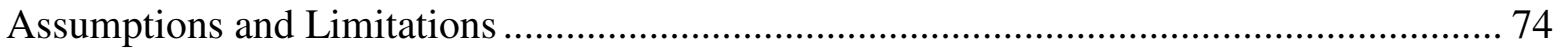

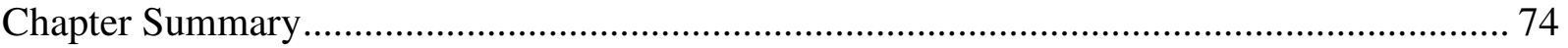

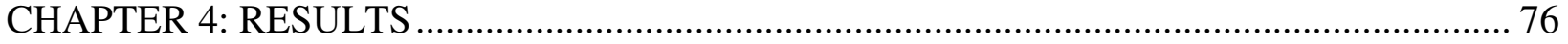

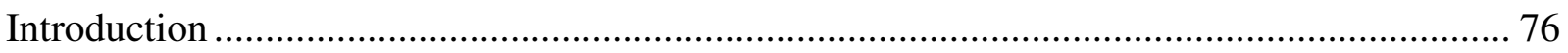

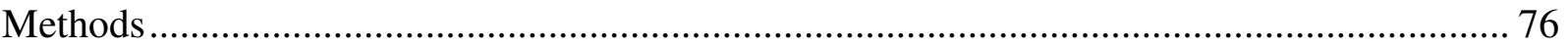

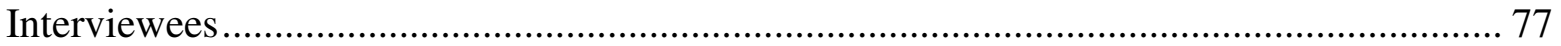

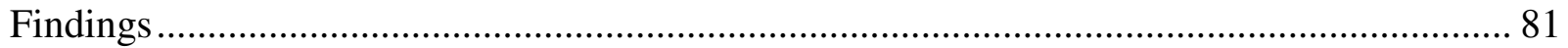

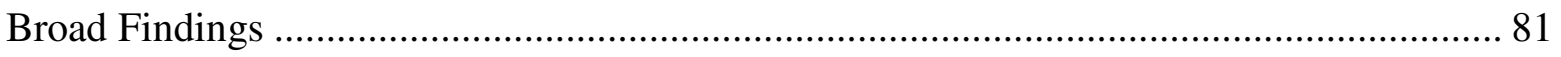


Relationships within collaborative environment. .................................................. 81

The benefit of quality early childhood settings and experiences .................................. 84

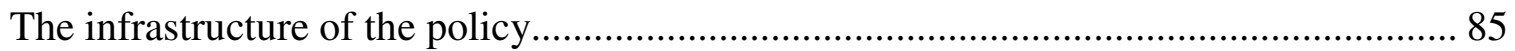

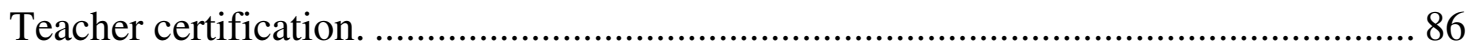

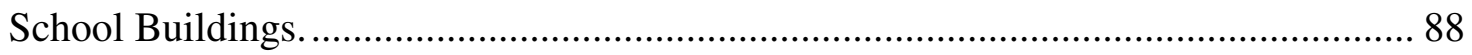

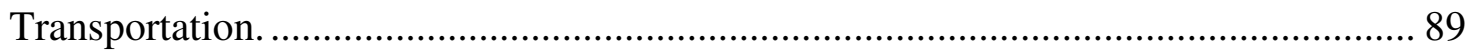

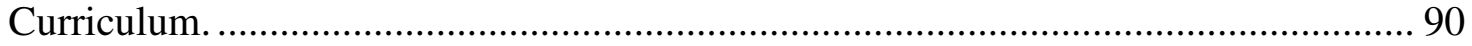

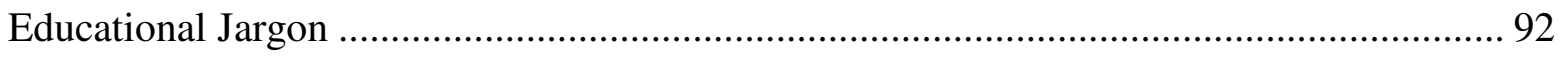

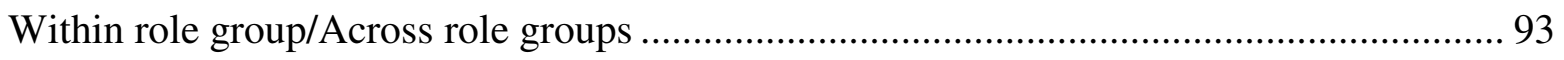

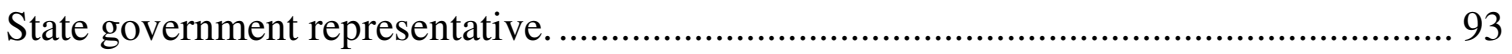

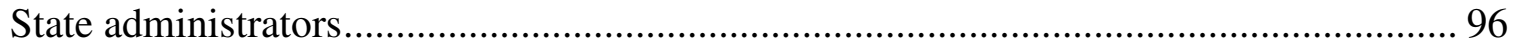

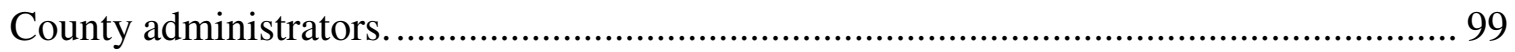

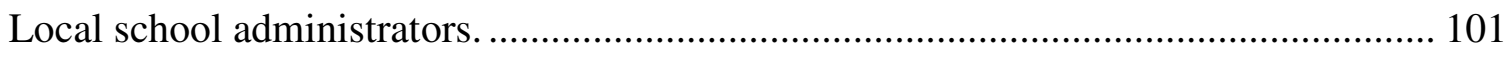

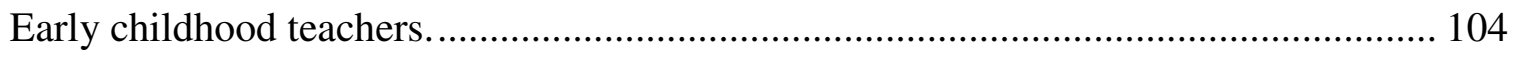

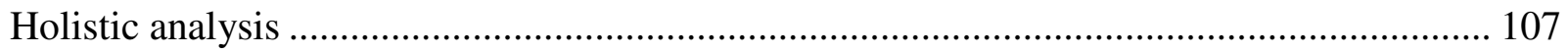

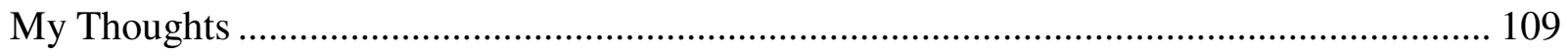

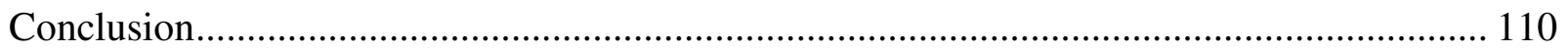

CHAPTER 5: CONCLUSION ................................................................................... 112

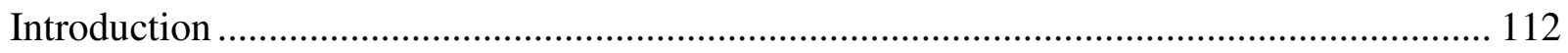

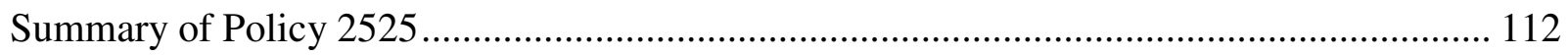


Previous Literature ............................................................................................. 112

Implications and Suggestions ............................................................................ 114

Implications for policy makers ........................................................................... 115

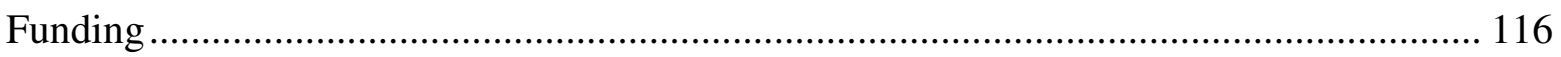

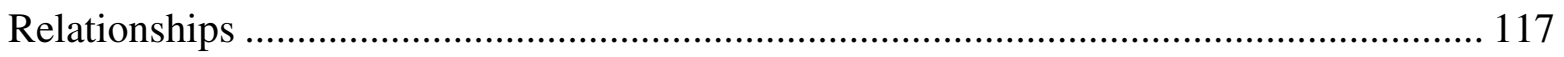

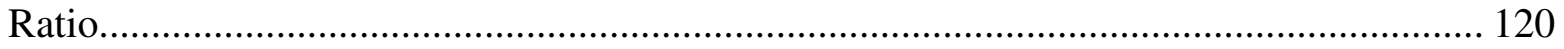

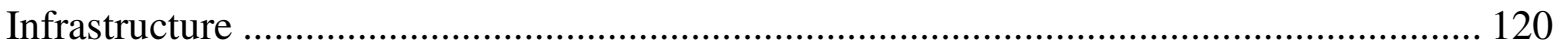

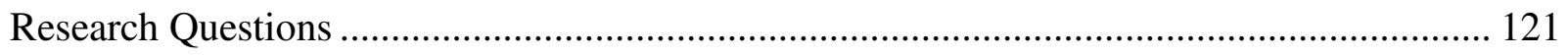

Research Question 1 .............................................................................................. 121

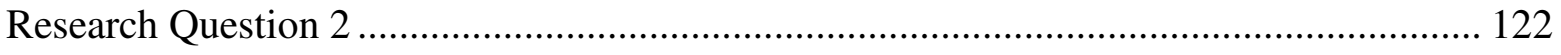

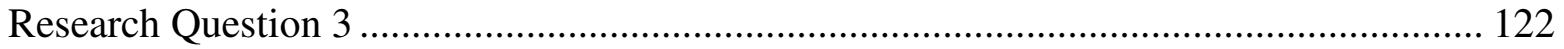

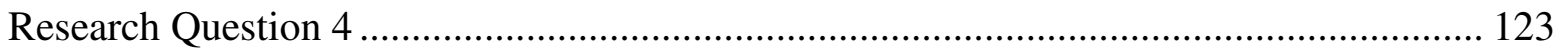

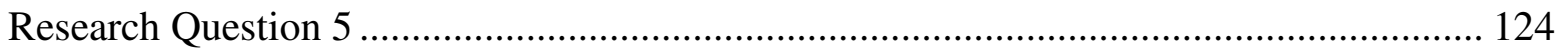

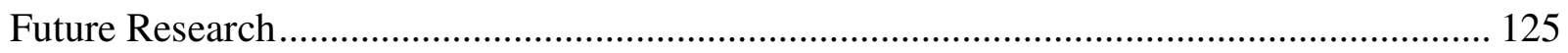

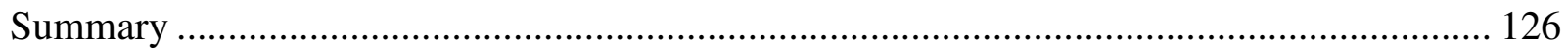

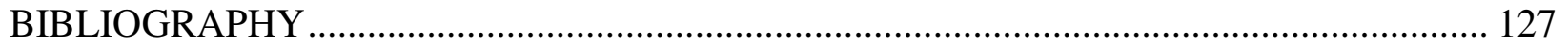

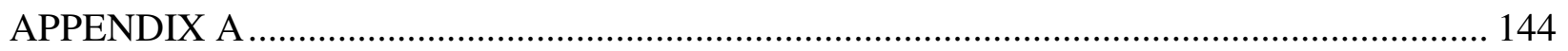

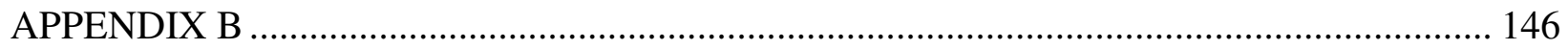

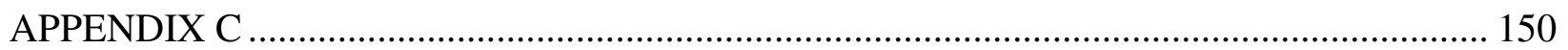

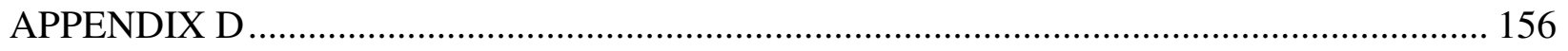

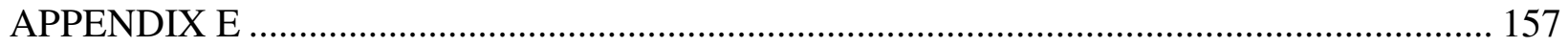




\section{CHAPTER 1: INTRODUCTION}

Early childhood is a great opportunity to establish a foundation for children based on early learning opportunities and supportive familial relationships. Often families choose to place their child in a preschool setting, which may be religious, public, or a private center. Families may spend a great amount of time and money researching what is best for their 4 - year - olds in terms of a preschool setting.

There are several criteria which all high quality preschool centers possess; they encourage whole child development, provide an opportunity for families to feel safe when they drop off their children, and improve overall performance with regard to high school graduation, college attendance rates, lower reliance on welfare, and lower rates of criminal activity (Beatty, 1997, p. 202; Belfield, 2006). Early childhood is a critical time for the future development of children, which should be embraced and viewed highly.

\section{My Interest}

This dissertation will review the perspectives of West Virginia educators on the implementation of the universal preschool policy. The topic is one that evokes interest from teachers, parents, researchers, policy makers, and presidential candidates. For me, the interest developed on a personal level in 2000, when I was hired as a long term substitute teacher in a Head Start classroom in Harrisonburg, Virginia. I was completing my master's degree and my only prior experience was the few hours a week I had logged in for class time at the West Virginia University Child Development Laboratory-The Nursery School, during my undergraduate education. The Head Start experience stimulated my passion for teaching 4 - year - olds, especially disadvantaged and poverty stricken children. After receiving my master's degree, I moved to Charlotte, North Carolina, where I had accepted a preschool teaching position 
The three years I spent there confirmed my passion for early childhood education. I sought to better understand the children, where they came from, their home life and their journey as they moved to kindergarten. I found myself attending a variety of meetings involving Bright Beginnings, a Title One, child-centered, literacy focused curriculum designed to prepare children for school. This program served mainly low-income and English as a Second Language children. I found myself wondering from where this program arose and how did it come about? When I left Charlotte and returned to Morgantown, West Virginia, in 2004, I again found myself in a Head Start classroom. This time I had the opportunity to spend time in more administrative meetings, which created more unanswered questions than before. I wondered why teachers adhered to Creative Curriculum, why they were responsible for brushing the children's teeth, why they received money that was designated Head Start funds, and why they and their classrooms were quality measured by ECERS (Early Childhood Environment Rating Scale). I questioned "why" things were done the way they were, "not whether the programs were beneficial or necessary."

Although these questions were in my mind, I never asked others about them; thus, they never were answered. It was not until I entered the doctoral program in Curriculum \& Instruction that I began to consider the policy behind the implementation. At that point, I recognized an opportunity to work on a dissertation that would give me a different perspective on the subject, as well as a better understanding and appreciation of West Virginia's Universal Access to a Quality Early Education System (Policy 2525).

\section{Dissertation Chapters}

This dissertation consists of five chapters. The first chapter describes the importance of early childhood education in my life and how it has influenced my dissertation topic. It also 
provides the reader with the significance of the study, the research questions, and my limitations and assumptions throughout the qualitative research.

The second chapter is the literature review, which explores the history and global influence of early childhood education, West Virginia's Universal Access to a Quality Early Education System (Policy 2525), the necessity of early childhood education, and the characteristics of what the research suggests is a quality early childhood education.

The third chapter identifies the sources from which my evidence was gathered; being thirteen qualitative interviews with state administrators, county administrators, principals, and early childhood teachers.

The fourth chapter provides readers with specific information obtained from the thirteen qualitative interviews. The emerging themes from the interviews are reinforced with direct quotations, which give the reader information regarding their positions in early childhood education and their perspectives, as West Virginia educators, on early childhood education.

The fifth and final chapter, utilizing information from the qualitative interviews and my own personal experiences, discusses the common themes which have been identified, to provide an understanding of the impact of early childhood education and the reasons behind the implementation of the Universal Preschool Policy. It is hoped that this culmination offers readers a better understanding of early childhood education in West Virginia, specifically with regard to Policy 2525. The final chapter also includes implications for further research based on the findings and limitations of my dissertation.

\section{A Broad Influence}

Interest in early childhood education is widespread throughout the world, as many countries desire to nurture and protect their children through education. The United Nations 
Children's Fund (UNICEF) has created a partnership with the Yale Child Study Center and the National Center for Children and Families (NCCF), Teachers College, Columbia University, to develop a system of standards for early childhood education in other countries, which are designed to improve programs and services for young children. The project began with six countries (Brazil, Ghana, Jordan, Paraguay, Philippines, and South Africa) and recently spread to a total of twenty countries. The survival, development, protection and participation needs of children are the focus of the many countries developing these social and public policies ("International Early Childhood Policy," 2008).

\section{History of EC education from Gesell to HS to Universal Preschool}

Interest in early childhood education began in the 1700s. But, it was not until the early $20^{\text {th }}$ century that Arnold Gesell, while studying under G. Stanley Hall and earning his Ph.D. from Clark University, advanced ideas which became the basis for many early childhood theories focusing on the children's environment. His most influential studies describe children's physical, social, emotional achievements, and developmental milestones in ten major areas. These areas included motor skills, personal hygiene, emotional expression, fears and dreams, self and sex, interpersonal relations, play and pastimes, school life, ethical sense, and philosophic outlook. His research led him to believe that children develop according to a predetermined plan of growth, which became known as the maturational perspective of child development. Dr. Gesell (1933, p. 232) wrote, "growth is a process so intricate and so sensitive that there must be powerful stabilizing factors, intrinsic rather than extrinsic, which preserve the balance of the total pattern and the direction of the growth trend. Maturation is... a name for this regulatory mechanism." His theory was based on his observation of large numbers of children of various 
ages and the development of norms from the children's achievement of various developmental milestones.

Dr. Gesell's work was greatly appreciated by parents because it described the typical behaviors to be expected of children at each age. Thus, developmental trends and expectations of children's individual development are often based on Dr. Gesell's foundational work.

Upon President Lyndon Johnson taking office, he built on President John F. Kennedy's War on Poverty. President Johnson stated, “That's my kind of program (in regards to combating poverty). I'll find money for it one way or another. If I have to, I'll take away money from things to get money for people (Vinovskis, 2005, p. 36). In 1965, President Johnson, as part of the War on Poverty, announced the beginning of the Head Start program, a comprehensive child development program geared to breaking the "cycle of poverty." President Johnson officially called the initiative "Head Start" at the message to Congress regarding the state of the union on January 4, 1965. Head Start began as an eight-week summer program, but has since touched over 22 million low-income children and families in the United States.

The opening of Head Start was endorsed by the mass media. The Washington Post wrote, "The preschool projects outlined by the President in his education message on Tuesday are perhaps the most imaginative and hopeful aspects of the whole education program. They afford a possibility of getting at the root cause of school dropouts; and they may serve to make education meaningful in later years to innumerable young students who otherwise would be wholly unprepared to receive it or benefit from it" (Vinovskis, 2005, p. 74).

The Head Start Planning Committee consisted of Shriver's personal friends or were coworkers at some point. Edward Zigler, a committee member, recalled, 
Few of us on the Planning Committee really believed that an eightweek summer program could produce many lasting benefits in children's lives; we certainly didn't think that a couple of meals a day and some vaccines could 'cure' poverty...The program certainly wouldn't do any harm; it might even do some good (Vinovskis, 2005, p. 78).

Today's preschool education is distributed unequally, because Head Start reaches only low income and special needs families. Children from more affluent households are required to pay for their preschool program, if a private program is available. Universal preschool is designed to provide all children, regardless of income or location, a program of quality. A federally funded universal system will shift the responsibility for all preschool education to the public schools.

\section{Political Influence}

In the United States, preschool education is a popular topic in both the political and educational world; however this popularity is not entirely new. In 1999, Senator Edward Kennedy introduced a bill to create a $\$ 2$ billion a year Early Learning Trust Fund providing states with matching grants for the establishment of full-day, full-calendar-year early education programs (Rhodes, 2000, p. 2). But, it was not until 2007, when President George W. Bush signed a bipartisan reauthorization of the "Improving Head Start for School Readiness Act", which included the requirement for teachers to have bachelor degrees, increased teacher salaries, and instituted state early learning councils ("Improving Head Start for School Readiness Act," 2007). 
In 2008, Presidential candidate John McCain stated, "School is charged with the responsibility of educating the child, and it (school) must have the resources and management authority to deliver on that responsibility" (McCain \& Palin, 2008). Senator McCain advocated for all students to have access to schools that demonstrate excellence. While both 2008 Presidential candidates verbally responded to the cry for better early childhood education, the true test will be the actions of President Barack Obama.

On other political fronts, rallies have occurred to give children and families a voice in the election. On September 23, 2008, a "Step up for kids" rally was held on the steps of the state capital in Albany, New York. Also, in the first week of September 2008, U.S. Education Secretary Margaret Spellings announced that Des Moines public schools received \$4.3 million for an Early Reading First Grant. This grant is intended to help more than 400 preschools with the critical foundation of reading (US Department of Education, 2008).

Currently, President Barack Obama has a plan labeled "Zero to Five, which he hopes to implement nationally. It is based upon his own work in Chicago's public schools. "One of the biggest lessons Mr. Obama drew from his experiences in Chicago, associates said, is student achievement is highly dependent on teacher quality" (Zeleny, 2008, p. A21).

Standards have become the norm for the United States public school system (Scott-Little, Kagan, \& Frelow, 2004). The foundation for accountability in the early childhood focused movement lies in these standards. From the beginning, early childhood has been exempt from the principles based education movement. Advocates have been wary because the "nature of development and learning at this age does not lend itself to standardization" (Scott-Little et al., 2004). The Current Population Survey (CPS) notes that in 2006, 4.6 million children, ages 3 to 5, were enrolled in preschool (Davis \& Bauman, 2008, p. 3). Although the numbers appear to 
be small, this represents a substantial increase over earlier decades (Barnett \& Yarosz, 2007, p. 1). Nationally, 3 to 5 - year - olds enrolled in school increased from 1994 to 2006 - from 53 to 60 percent for 4 - year - olds and 33 percent for 3 - year - olds (Davis \& Bauman, 2008, p. 3).

\section{Policies}

Due to the demand for an increase in early childhood care, national early childhood policies were developed and implemented. In 1988, "Goals for Education: Challenge 2000” was developed through the Southern Regional Education Board (SREB) in which West Virginia obtained membership. The task was to develop a report regarding full-day preschool and full-day kindergarten to all at-risk children (Bushouse, 2007, p. 5). Because continued economic growth was a concern for these southern states, it was believed a strong public school system, which invested in a better educated workforce, would be a draw for professional workers to relocate to southern states. One way to develop a strong public school system was to institute universal preschool. Therefore, three factors drove the rise of universal preschool movement: " 1 . Absence of federal policy action, 2. Emerging research on the importance of early brain development, and 3. Publicity surrounding longitudinal studies of preschool participation" (Bushouse, 2007, p. 5). These factors and the lack of federal action resulted in support for a policy change.

A Call to Action has been offered to the $110^{\text {th }}$ Congress on behalf of NAEYC with regard to a federal commitment to the goal of providing children with the early development and learning experiences that make them successful in school and beyond (NAEYC). This Call to Action addresses four areas: a high-quality workforce and career system, a continuum of positive development and learning, a systems collaboration to support young children and families, and an expansion of access to high-quality programs. In 2007, The National Child Care Association (NCCA) called for a public policy to enhance the availability of early childhood education based 
on the following six principles: opportunities for every child, long-term sustainability, coordination at both federal and state levels, licensed age appropriate environments, parental choice, and a professional workforce.

\section{West Virginia}

A substantial commitment to early childhood development in West

Virginia will be a very positive factor influencing the future

economic development of the State, probably more important than

any other effort currently underway (C. Kent, Hamilton, Risch,

Sowards, \& Rusalkina, 2005, p. 6).

This dissertation will focus only on West Virginia universal preschool policy. In order to fully understand the policy, one needs to understand the state of West Virginia. It is sparsely populated and widely dispersed over its mountainous terrain. People over the age of 65 comprise the fastest growing; segment of the population within the state. Its rate of economic growth consistently falls behind that of the nation. It also has one of the lowest rates of college attendance and the fewest number of persons holding college degrees or technology certificates. Specifically, it has the "lowest percentage of its adult population 25 years of age or older, with a bachelor's degree, and (it has been concluded)the education level of parents is a strong indicator of how their children will perform in school" ("Senate Bill 498," 2009).

The low rates of higher education attainment are, at least, partially attributable to the fact West Virginia has a declining student enrollment in its public schools. As concluded in Senate Bill 498, "excluding projected increases due to increases in enrollment in the early childhood education program, projections indicate that total student enrollment in West Virginia will 
decline by one percent, or by approximately two thousand seven hundred four students, by the school year 2012-2013. Declining enrollments will be offset by county boards enrolling 4 - year - olds. Another factor in these low rates may be because a majority of government funded educational programs in West Virginia are underfunded, with salaries falling below the national and regional averages. However, in reference to universal preschool, West Virginia has received national attention for being on the forefront of the initiative (C. Kent et al., 2009, p. 39).

Advocates argue that early childhood education is providing a foundation for children to become productive, contributing members of society (Barnett \& Hustedt, 2003, p. 54; Committee for Economic Development, 2002). As James P. Comer, in School Power. (1980, p. 16) wrote,

The innovative teaching and curriculum programs created over the last two decades were designed in response to the broad societal changes and problems... The objective of most has been to develop and educate the whole person - the societal, emotional, moral, psychological person and not just the intellectual person.

Motivation and development of children to the point that they are capable of desirable social and interpersonal behavior cannot be provided adequately through the provision of information or symbolic acts alone. Teaching material, curriculum programs such as values clarification and others are not enough. Nor is (are) isolated rituals such as a pledge to the flag or a morning prayer 
enough. Social, psychological, and moral development is fostered in largest part, by the living experience of the child at home, in the neighborhood and in school - the way he or she is treated by parents, principals, teachers, and others. A child's experience is the model and motivation for his or her style and quality of treatment of others, people and property (Comer, 1980, p. 36-37).

Furthermore, NAEYC's public policy states that several decades of research clearly demonstrate that high-quality, developmentally appropriate early childhood programs produce short- and long-term positive effects on children's cognitive and social development. It is hoped that by making preschool available throughout the state, it will open the door for parents to both work and feel that their child is in a safe and educational environment (Barnett, Brown, \& Shore, 2004, p. 4).

Another historical change which increased the need for early childhood education is the increase in the number of mothers working outside the home. In 1996, the Personal Responsibility and Work Opportunity Reconciliation Act (PL 104-193) “changed the social policy landscape for children" (M. H. Greenberg et al., 1996, p. 27). This act provided child care assistance to low-income families so the parents could pursue employment, job training, or education. The Internal Revenue Code also has encouraged work outside the home by providing aid to working parents through the Dependent Care Tax Credit (DCTC) which is a tax credit of $\$ 3000$ for one child or $\$ 6000$ for two or more children (Internal Revenue Service United States Department of the Treasury, 2008). 
As the economic needs of households have continued to demand two incomes, working parents wonder to whom they should entrust their children. Over the past year, with the sluggish economy and companies downsizing, the question of what to do with the children (while their parents seek or have employment) becomes more critical, as parents throughout West Virginia struggle with child care needs.

However, the issue of early childhood education runs much deeper than just an economic boost to the state; early childhood education is (more importantly) an intervention intended to promote school readiness for all children. While West Virginia is in critical need of quality early childhood preschools, a problem arises in defining what is "high quality." This problem was recognized by the West Virginia state legislature when they passed Senate Bill 247, now West Virginia Education Code §18-5-44 ("Early childhood education programs," 2002),Senator Lloyd Jackson, chairman of the Senate Education Committee, was one of the leaders in gaining passage of the bill. Senator Jackson had an interest in the measure because he knew that based upon brain research and personal history, it was a worthy program and he had a desire to leave a legacy of improved educational outcomes for West Virginia's children” (Jackson, 2005). He was also planning to run for governor in 2004 and he wanted to be able to implement the new program which he believed to be so valuable. The bill which created a universal prekindergarten program was supported by legislators, top political appointees of the state Department of Education (DOE), and the Department of Health and Human Resources (DHHR) (Bushouse, 2006). One problem was that, while the universal preschool program was desperately needed, the people implementing it were neither in attendance nor consulted during its formation. In order to avoid losing Head Start money, the legislation included Head Start's "involvement with any expansion of publicly funded pre-k"(Bushouse, 2007, p. 16). Therefore, this requirement of 
Head Start's continued involvement has resulted in various implementations of the same policy throughout the state of West Virginia. In drafting the legislation, the education committee had decided on a ten year implementation framework to develop the program, build political support, and dispel any controversy surrounding the program (Jackson, 2005).

However, in the end, Jackson was defeated in the primary and West Virginia preschool lost one of its strongest advocates. None the less, The National Institute for Early Education recently released that West Virginia was ranked among the five "best chance" states for parents to find a high-quality, state funded pre-k program (Rosenberger, B. December 20, 2008, The Herald-Dispatch, PreK program earns praise). West Virginia has also been "applauded for its steady pace and unique approach to building a quality pre-k program” (Rosenberger, B. December 20, 2008, The Herald-Dispatch).

In addition, higher education has also begun to play a vital role in West Virginia early childhood education. For example, Marshall University received \$300,000 from the Benedum Foundation to provide sustained professional development and overall early childhood education throughout West Virginia (Wellman, 2006). As a result, Marshall University Early Education Center (MUEEC) coordinator, Monica DellaMea has said, "The impact of this training model will ultimately benefit preschoolers throughout the state, because these children will be provided more opportunities for critical thinking and the development of other $21^{\text {st }}$ century skills" (Wellman, 2006).

So, although West Virginia has had numerous geographical, social, demographic and political hurdles, it has recognized the importance of early childhood education and it continues to work to find ways to overcome those hurdles. 


\section{Significance of Study}

The National Association for the Education of Young Children's public policy, Call to Excellence, states that the demand for early childhood care and programs continues to increase due to the demand for out of home child care as well as the recognition of the critical importance of educational experiences during the early years. The national trend is the preschool initiative. Preschool classrooms are found in thirty-eight of the fifty states (National Institute for Early Childhood Research (NIEER), 2007).

\section{Philosophical approach to early childhood education}

The Center of the Developing Child at Harvard University (2007, p. 2) proposed that advances in the sciences of early childhood and early brain development, combined with the findings of four decades of rigorous program evaluation, can now provide a strong foundation upon which policymakers and civic leaders with diverse political values can design a common, effective, and viable agenda. Research in neurobiology links the interaction between genetics and early experiences that shapes the brain (National Forum on Early Childhood Program Evaluation, 2007). The plasticity of the brain is most favorable in early childhood which is important in the development of intelligence and abilities. By promoting this healthy development, a foundation is laid for greater school achievement, economic productivity, responsible citizenship, and successful parenting.

Early childhood is a time of rapid development. Social behaviors and problem solving abilities are being explored. These pre-literacy skills are critical in setting a foundation for further developmental skills. A child's play is his or her means for creative learning and thought and the experiences that children have with people impact their brain structure. This is a continual process that builds upon the previous skills, all being interconnected. 
The scientific research regarding the development of the child will help guide policy and practice.

\section{Academic push-down}

At one time, finger paint, recess, music and dramatic play were prevalent in classrooms. However, this is being replaced by an academic approach which increasingly places pressure on children, as early as preschool and kindergarten years. The academic stress is evident in preschool and kindergarten classrooms via the push for children's readiness to advance to the next grade level (Katz, 1999) and the monitoring of children through standardized testing. Kindergarten programs in the United States have been transformed. For the most part, in earlier years, "they (kindergarten programs) consisted mostly of part-day programs and focused on easing young children's transition to school by providing opportunities to socialize and play in group settings" (Votruba-Drzal, Li-Grining, \& Maldonado-Carreno, 2008, p. 957).

In the early 1900s, Maria Montessori's educational approach used concrete materials and experience as a foundation; there was no pressure from an academic curriculum. The focus was in the natural development of children, the observation of the child in his or her environment, and the individuality of the child. The Montessori whole child approach is still used throughout the world and influences the preschool realm.

The Association for Supervision and Curriculum Development (ASCD) (2008) advocates the whole child approach through their whole child resolution tool kit. Arming students with a "well-rounded, challenging education" means ensuring that the student is healthy, safe, engaged, supported, and challenged believes ASCD (2008). These beliefs fall in line with the Montessori's approach. ASCD (2008) and Montessori share the belief that education should be a "personalized engagement and nurturing of the whole child." Learning environments will begin 
to "weave together the threads that connect not only math, sciences, the arts, and humanities, but also mind, heart, body and spirit--connections that tend to be fragmented in our current standards based approach (2007, p. 2). This approach, from ASCD, allows students to develop to their fullest potential.

The Reggio Emilia approach continues to influence preschool education. Many practices are based upon the philosophy that children have some control over their learning, they learn through experience, they form relationships, their world must be explored, and they engage in a variety of learning styles. In other words, children develop naturally. The Reggio Emilia approach is deeply imbedded in practice and theory, especially those of Dewey, Piaget, Vygotsky, Gardner and Bruner.

Currently, movements also have been made toward a more play oriented program, with professional early childhood education organizations being part of the endorsement. The focus is returning to creating lifelong learners instead of efficient test-takers. Preschool children in child initiated programs displayed lower levels of test anxiety than children enrolled in academic programs (Burts, Hart, Charlesworth, \& Kirk, 1990). As Pablo Casals (The Association for the Supervision and Curriculum Development, 2007, p. 5) wrote,

Each moment we live never was before and will never be again. And yet what we teach children in schools is $2+2=4$ and Paris is the capital of France. What we should be teaching them is what they are. We should be saying: "Do you know what you are? You are a marvel. You are unique. In all the world, there is no other child exactly like you. In the millions of years that have passed, 
there has never been another child exactly like you. You may

become a Shakespeare, a Michelangelo, a Beethoven. You have the capacity for anything. Yes, you are a marvel.

In this approach, the student is at the center of learning. "Play is essential to development because it contributes to the cognitive, physical, social, and emotional well-being of children and youth" (Ginsburg, Committee on Communications, \& Committee on Psychosocial Aspects of Child and Family Health, 2007, p. 182) for the American Academy of Pediatrics. During this indoor and outdoor (play) time, children's creativity is permitted to be expressed. The world around them is allowed to be tested and experienced in a safe environment. They learn how to become friends, work in groups, practice decision making skills, follow rules, and resolve conflicts. Children are permitted to test hand-eye coordination, fine motor development, analytical thinking skills, and an increased complex play level. Play allows children to express themselves and investigate their world. Vygotsky (1978) believed that play leads to development. This child-initiated, social-emotional learning is helpful in the academic arena and supports learning.

Play permits students to explore roles within their school and their community. The School Development Program (California Department of Education, 2005) emphasizes that a student's sense of community is connected to achievement.

\section{Developmentally Ready}

A linear policy does not always align with the pedagogical beliefs of early childhood education. The issue becomes: Are preschool children developmentally ready to experience the 
academic rigor often associated with a school setting? Children who attend developmentally appropriate programs are more confident in their own cognitive ability (Burts et al., 1990).

The notion of school readiness lies in the foundation of NAEYC's position statement entitled Developmentally Appropriate Practice in Early Childhood Education Programs Serving Children From Birth Through Age 8 (Bredekamp, 1987; Bredekamp \& Copple, 1997). It has been an influential document in early childhood practice. This position statement has driven early childhood education and emphasized the importance of the early learning experiences.

While NAEYC's statement has influenced early childhood, a problem arises when a preschool enters an elementary school. The philosophy of the school often discourages the core values delineated in the position statement. NAEYC's principle number nine states, "Play is an important vehicle for children's social, emotional, and cognitive development, as well as a reflection of their development" (Bredekamp \& Copple, 1997). Often when placed into an elementary school, the role of play in the classroom is diminished. As noted in the section on academic push-down, play supports cognitive, physical, emotional, and social development (Ginsburg et al., 2007).

Young children learn through experience better than through direct instruction. At the age of four, it is an unrealistic expectation for children to sit and listen to a lecture for an hour. A developmentally appropriate approach might see children experiencing apples at the science center, reading stories about apples, or engaged in selling apples in dramatic play while the teacher is circulating and conversing with the children at their centers. Jean Jacques Rousseau (1762, p. 142) wrote in Emile, "Let him know nothing because you have told him, but because he has learnt it for himself." 


\section{Research Questions}

After reviewing the literature and my personal experiences, the following research questions have emerged.

1. How do participants define their roles in the implementation of universal preschool education in West Virginia?

2. What are the participants' understandings of the goals of universal preschool education in West Virginia?

3. What are the participants' perspectives of the benefits and challenges of universal preschool education in West Virginia?

4. How is universal preschool being implemented in West Virginia?

5. How does the enacted policy compare to the legislated intent of the policy? Interviews of a state government representative, early childhood state administrators, early childhood county administrators, principals that house early childhood classrooms and early childhood teachers were conducted to identify West Virginia's purpose in implementing the Universal Access to a Quality Early Education System (Policy 2525). 
Figure 1

Interviews

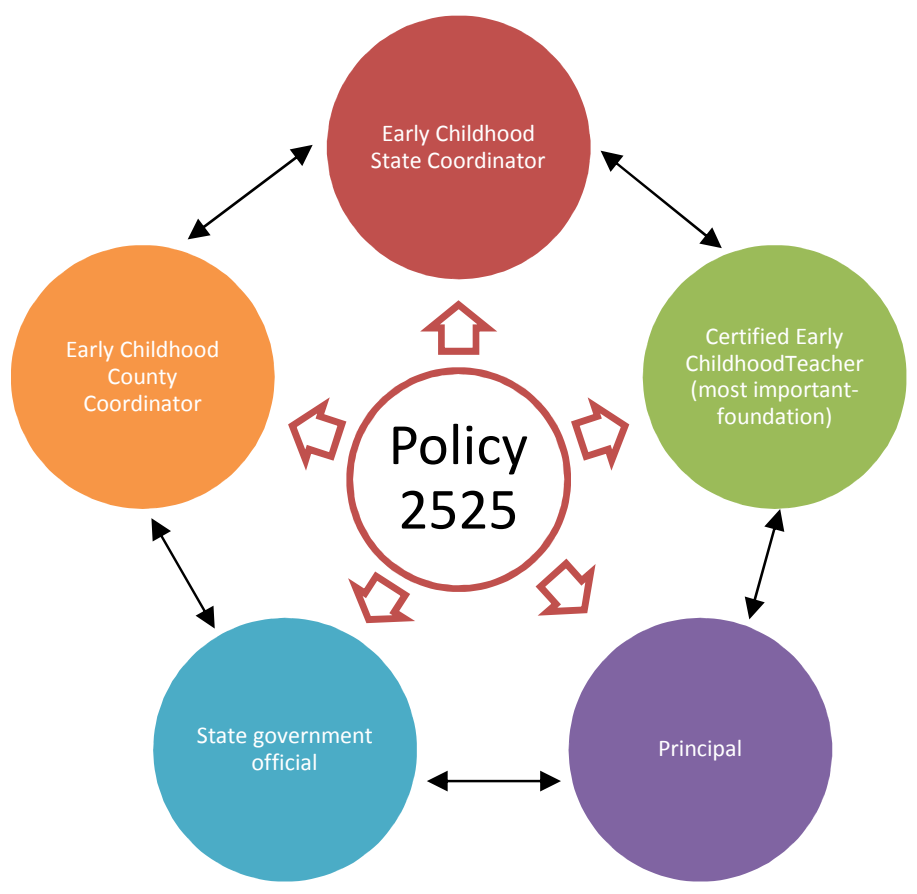


While understanding the goals of universal preschool education in West Virginia is my initial focus, I also understand that questions will emerge that I am unable to predict. Theoretically, the goals of Policy 2525, Research Question 2, should match the implementation in every county. Based on the research questions, insight on this theory will be provided by utilizing my interviews with thirteen people involved in various early childhood roles.

\section{Limitations and Assumptions}

I enter this investigation from a variety of perspectives. As a former early childhood teacher, I have several preconceived notions regarding early childhood education. First, every child is unique and enters with varying personal experiences, environmental factors, and different potentials of development. These qualities need to be acknowledged and recognized as unique, and such variations should be reflected in the curriculum. Second, children learn though discovery of the world around them, group play, manipulation of objects in their environment, creative play, and independent play. Educators are successful only when parents and community encourage and support life-long learning. Loris Malaguzzi (1998, p. 78-81) summarizes this particular notion in an interview about the Reggio Emilia approach given to Leila Gandini.

All people, who in any place have set themselves to study children seriously-have ended up by discovering not so much the limits and weaknesses of children but rather their surprising and extraordinary strengths and capabilities linked with an inexhaustible need for expression and realization ... children are autonomously capable of making meaning from their daily life 
experiences through mental acts involving planning, coordination of ideas and abstraction. Remember, meanings are never static, univocal, or final; they are always generative of other meanings. The central act of adults, therefore, is to activate, especially indirectly, the meaning-making competencies of children as a basis of all learning.

Third, in terms of documentation, both teacher and child are to be actively involved in the process. The child's role is associated with the at-task learning experience while the educator is focused on how and what the child is learning as he or she is engaged in the experience (Edwards, 2005, p. 78). Dahlberg, Moss, \& Pence (1999, p. 153) wrote,

Because documentation can be kept and returned to, and must be seen all the time as a living record of the pedagogical practice, the process of documentation can also function as a way of revisiting and reviewing earlier experiences and events, and by doing so not only create memories, but also new interpretations and reconstructions of what happened in the past. Through this, active pedagogues will be able to build on and utilize well-established experiences and simultaneously take part in constructing new theories concerning children's learning and knowledge construction, with documentation as a base. 
Since I recognize the notions, I will strive to further my understanding of early childhood, especially the implementation of West Virginia's Universal Access to a Quality Early Education System (Policy 2525). In understanding this, my goal is to recognize that my initial ideas may not always be best suited for early childhood as a whole.

Another perspective is as a parent of a toddler preparing to enter the preschool educational system in the 2009-2010 school year, which further clouds my personal lens. I seek to understand early childhood policies and those in opposition, because, as parents, my husband and I have searched to find a quality preschool educational setting for our son. Having received my Bachelor of Science in Child Development and Family Studies, my Master of Teaching in Early Childhood Education, and pursuing a Doctor of Education, specializing in Early Childhood Education, there are certain ideas and criteria that I expect to see in a classroom.

Finally, as a West Virginia native, my interest lies deeper than just an interest in an educational system; the success of West Virginia, a home that I love, is personal to me. My beliefs reflect an understanding different than those of an administrator or a director. During the qualitative interviews, I recognize that my opinions need to be set aside as best as possible to ensure objectivity but remain a human as a researcher. This will allow me to more fully understand alternatives to early childhood education as I perceive it.

In terms of the research study, my questions will involve the interviewee's perception of an implemented policy. Their positions and overall satisfaction and happiness in the educational system may influence their responses. This limitation is noted and will be recognized throughout the dissertation. 


\section{Chapter Summary}

The call has been placed upon early childhood coordinators and teachers to implement a policy within West Virginia. While this policy provides them a guide to its execution, it also charges them with understanding early childhood history, becoming well trained, and providing the best possible services for children. This study will provide a glimpse into several counties in West Virginia and the implementation of Policy 2525.

As a researcher, an early childhood educator, and a parent of young children, I have a vested interest in early childhood education. Fully understanding the limitations this creates, I hope to guide the reader, as well as myself, through a journey to a better understanding of Policy 2525 in West Virginia.

\section{Definitions of Commonly Used Terms}

Throughout this dissertation a variety of words will be used that need to be commonly identified.

Developmentally appropriate: An early childhood perspective based on practice and theory.

Early childhood: For the purposes of this dissertation, early childhood is the time between infancy and entering kindergarten, especially between 3 and 4 year olds.

Head Start: A national, federally funded preschool program for 3 - year - old and 4 - year -old children emphasizing the whole child.

Low-income: Falling below the federal poverty guideline.

Montessori: An educational belief system developed by Maria Montessori encompassing creativity, problem solving, critical thinking and time management skills: uninterrupted and individual work is respected. 
National Association for the Education of Young Children (NAEYC): National organization that promotes excellence in early childhood education

Preschool: An early childhood setting appropriate for children prior to entering kindergarten.

Reggio Emilia: An Italian based educational system supporting the natural development of the child: it focuses on the interests of the child.

Title-One-Improving the Academic Achievement of the Disadvantaged: Declaration from the government that all children will have an opportunity to a high quality education.

Universal preschool: Preschool available to all families.

Voluntary preschool: Preschool available to all families but not mandatory.

West Virginia's Universal Access to a Quality Early Education System (Policy 2525):

West Virginia's implementation guidelines for 3 - year - old and 4 - year - old children entering preschool. 


\title{
CHAPTER 2: LITERATURE REVIEW
}

\author{
Introduction
}

This literature section reviews not only the contributions from the United States but also those from our global neighbors regarding preschool education. Funding is an essential part of early childhood and the impact varies across federal, state, or county budgets. This chapter also looks at the necessity for quality preschool classrooms and why it has become an obligation for policy makers, teachers, university researchers, community members, parents, students, and professional organizations to become involved and express their educated opinions.

From this perspective, the challenge is not just choosing a curriculum, providing some professional development, or creating a program, but building a comprehensive early childhood system where families and communities help support the social, emotional, and cognitive growth children need to be successful as they enter and continue through school (L. Klein \& Knitzer, 2006, p. 10).

As the literature reflects, preschool education is not enclosed in a vacuum but in a vast history that is the result of an array of influences from educators, students, teachers, curriculum, and families.

This literature review begins with early childhood education's roots in the 1700s. History illustrates that changes have occurred due to different situations in society and the environment, from war to poverty. This early childhood journey is one of innovation and change. The ideal 
that has remained constant is the focus on what many believe is best for the child. In today's system, the child is often swept away in the undercurrent of legal jargon and money ventures. Our call is to reflect upon the perceptions of early childhood education, specifically West Virginia's Universal Access to a Quality Early Education System (2525), and how we can take those perceptions, merge them, and enhance the education of children and the support for their families.

\section{Preschool}

Concern for preschool education not only encompasses the United States but many other countries. France, Germany, Denmark, Greece, England, Luxembourg, Netherlands, Italy, Spain, and the United States all offer some form of preschool; although, the variation in programs is drastic. There are a variety of well recognized methods employed globally from Montessori, Waldorf, High Scope, Reggio Emilia, Forrest, and Bank Street. There are also different theories that are employed, such as whole child and play based curriculums. Typically the age of the children range from three to five years old. Preschool is also referred to as nursery school, day care or kindergarten.

Parents have choices when it comes to preschool. They can choose from the public, private, or religious sector. Their choices are based on several factors, including cultural views, money, and educational experience. It is a decision that is not taken lightly. Many hours are spent making this choice. If the culture places a priority on mothers staying home to care for their children, the family decision may not include preschool as an option. Second, family income is critical in deciding the child's preschool. The private and public sector are expensive in tuition cost while the public sector is normally free. Last, the educational experience of the parents is influential in the preschool choice. 
Early childhood education has received increased attention in the United States in both the "public and the private sector"(American Association of Colleges for Teacher Education (AACTE), 2004, p. 3). It is often recognized in political discussion, including the 2008 presidential campaign. Currently, with the multitude of problems that our country is facing, early childhood education has been placed on the government's backburner.

\section{Funding}

There is a wide range of preschool initiatives occurring in the United States and other countries and funding is central to many of them. Zigler, Gilliam, \& Jones (2006) write that the history of education in the United States shows universal preschool will be implemented state by state, district by district, and school by school. Neugebauer (2008, p. 26) also notes that funding follows a similar pattern that begins at the federal to state to local level. West Virginia is currently engaged in this trickle down process, but was ranked sixth in the nation by The State of Preschool: 2006 for providing access to state-funded early childhood education for 4 - year - old children (West Virginia Board of Education, 2006-2007). The only exception to federal control of early childhood has been the execution of the Disabilities Education Act and No Child Left Behind (Zigler, Gilliam, \& Jones, 2006, p. 3). Globally, several countries, including France, Italy, Sweden, Japan, England and Belgium, provide free or subsidized preschool education to nearly all 3 and 4 year olds. (Sacks \& Ruzzi, 2005).

In the United States, many states have begun individual initiatives by increasing funding for preschool programs (Neugebauer, 2008, p. 26). Traditionally, Title I funds are used and the children targeted live in poverty or exhibit other risk factors for school success. Several states have been on the forefront of this initiative; they include Pennsylvania (1965), Maine (1983), Oklahoma (1990), Georgia (1993), New York (1998), New Jersey (1998), and Florida (2005). 
Lynch, commissioned by the Economic Policy Institute in the United States for four longitudinal studies (Ypsilanti Perry Preschool Project; the Prenatal/Early Infancy Project; the Abecedarian Early Childhood Intervention; and the Chicago Child-Parent Center Program), noted, "ECD programs easily pay for themselves over time by generating very high rates of return for participants, public and the government. Good programs produce $\$ 3$ or more in benefits for every dollar of investment; Duncan, Ludwig, and Magnuson (2007) suggested a savings of 7:1 and Calman and Tarr-Whelan (2005) say the savings may be as much as $\$ 13$, making it one of the nation's most profitable social investments. While participants and their families get part of the total benefits, the benefits to the public and government are larger and, on their own, tend to far outweigh the costs of these programs, (Gammage, 2006, p. 244). Stoney (2004, p. 15) stated early development programs are, “. . . an industry worthy of investment and as an important infrastructure that supports economic growth."

According to Pre[K]now (Pre-K Now, 2005-2008), funding varies widely from $\$ 1,600$ per pre-k child in South Carolina to more than $\$ 10,000$ per child in New Jersey. In 2007, West Virginia enrolled $46 \%$ of its 4 - year - olds and spent $\$ 4,441$ per child enrolled, which did not include additional federal or local funding sources (National Institute for Early Education Research, 2007). According to West Virginia State School Superintendent, Steven Paine, "Marshall University researchers calculated that for every \$1 West Virginia spends on good early childhood development, the state saves \$5.20," (C. Kent et al., 2005). These numbers are based on the cost for additional services, especially special needs, through the life of the child in the public school system. It is said that West Virginia should view this as a "profitable investment for a state, not as a cost" (Committee for Economic Development, 2002). 
In order to facilitate expansion of the West Virginia Universal Preschool System initiative, the state policy requires that half of the programs operate in collaborative settings with child care, private prekindergarten, or Head Start. Federal Head Start, IDEA, and Title I funding are used to significantly supplement state funding for prekindergarten (National Institute for Early Childhood Research, 2007).

Due to the diversity of preschool settings, funding has continuously been an issue. Who will fund the initiative? How will the money be divided? Where will the money come from? What will the money go towards? Child care centers tend to have lower paid staff and higher turnover rates. In addition, they often require parents to pay a fee. On the other hand, if the word "education" is included or implied in the center, staff are often paid comparable fees and trained.

Transportation also continues to be an issue, especially in a mountainous state like West Virginia. State guidelines mandate a maximum travel time of 30 minutes for a preschool student. This is often difficult to maintain due to the terrain in the surrounding area. Eric Eyre, of the Charleston Gazette (2002), wrote, "West Virginia buses must traverse some of the toughest terrain in the nation."

\section{Preschool Advocates}

Throughout the history of preschool, supporters have had to fight the notion that children need not be rushed into a formal education system and are better off at home under the care of their mother, as well as what many believe to be the overwhelming cost. The National Institute 
for Early Education Research conducted a poll in 2001 and "revealed that nearly 90 percent of people who responded felt that there should be state-funded, universally accessible preschool" (Zigler et al., 2006, p. 3). With more than a million children attending state-funded preschools, this makes the state the principal source of public preschool. Currently, there are thirty-eight states that fund preschool. The following twelve states have no preschool system: Alaska, Hawaii, Idaho, Indiana, Mississippi, Montana, New Hampshire, North Dakota, Rhode Island, South Dakota, Utah, and Wyoming (National Institute for Early Childhood Research, 2007). The one item that is "nearly universally recognized is that access to high quality educational programs is a key component of improving child outcomes." (Pianta, 2006). "No Child Left Behind" of 2001 introduced accountability provisions for schools, increased proficiency goals for all students, and emphasized high quality instruction. The question has become: How is high quality education gauged? The answer is often based on student assessment, teacher credentials, or class size, but never by teacher student relationships or interactions (Pianta, 2006). Currently, West Virginia utilizes the Early Childhood Environment Rating Scale (ECERS) and the Infant and Toddler Environment Rating Scale (ITERS). For several years now, these tools have functioned as an assessment device linking policy and training to setting quality and child outcomes (Pianta, 2006).

The nature of preschool implementation seems to begin with high-risk students and includes poverty, low parental education, English as a second language, and progression toward universality. There is no set standard across the country; some states have universal preschool while others have no preschool and some have only targeted preschool, mainly for low-income families (Belfield, 2006, p. 3). As with the kindergarten education (Zigler, Gilliam, \& Jones, 2006, p. xv), it may be a slow movement but it is one that will encourage school readiness. 
Research notes that access to quality programs, qualified teachers, and an appropriate curriculum will bridge the gap for at-risk students (American Association of Colleges for Teacher Education (AACTE) Focus Council on Early Childhood Education, 2004, p. 3; Gammage, 2006, p. 236). The focus also lies on the "whole child." Preschool is a time when physical, emotional, psychological, mental, cognitive, spiritual, nutritional and verbal well-being may be addressed. This also encompasses the needs of the family (Barnett \& Belfield, 2006, p. 80; White, 2004, p. 667). Educators have an opportunity to focus more on pedagogical methods as well as psychological and sociological ideas about children and family (Beatty, 1997, p. 133, p. 133). Ultimately, the key to a successful child is a family that actively supports the child and his or her education.

\section{The Global Influence of Philosophers and Educators}

Philosophers and educators around the globe began focusing on early childhood education in the early 1600s. In the 1600s, the Czech educator and religious leader Johann Amos Comenius wrote the first picture book for children, Orbus Pictus, (Follari, 2007, p. 20) and developed an educational system for use from infancy to the university, The Great Didactic (Beatty, 1997, p. 1; Peltzman, 1998, p. 1). Approximately forty years later, an English doctor and philosopher, John Locke, produced a guide to education (Follari, 2007, p. 21) and argued that children are born with a blank slate (tabula rasa). Like Comenius, Locke thought that children should be educated in the home (Beatty, 1997, p. 4). Jean Jacques Rousseau, a French philosopher, later wrote books that "spawned education reform in Europe and America" (Beatty, 1997, p. 1; Follari, 2007, p. 22). His ideas were embedded in the need for motor activities, firsthand experiences, and games. Comenius and Rousseau provided philosophical roots to 
nursery education (Seifert, 2004). These three philosophers were concerned with what is essential for the children and addressed the issue of who should educate.

\section{The $1800 \mathrm{~s}$}

In the 1820s, Robert Owen focused on "spreading the infant school movement in America" (Follari, 2007, p. 24). During the same time the "father of the kindergarten," Friedrich Froebel, promoted a play based learning environment and opened the first kindergarten. $\mathrm{He}$ believed in the importance and significance in play and the impact on children's development. "Play is the highest phase of child development-of human development at this period" (Murray \& Smith, 2003) Play is at the center of the child's "natural life (Murray \& Smith, 2003, p. 135)." M.R. Hofer described,

(Froebel) recognized the necessity of bringing the world an all-sided development to the child through the many avenues of education already opened to him, he looked deeper and saw in the child, not only the imitator, but the creator; saw the necessity for arousing and leading forth this vital energy into all the child's doings in order to establish the full power of the individual. This creative energy he places in the play spirit of the child, which he calls the highest phase of human development of this period; the purest and most spiritual activity of man typical of human life as a whole. It holds the sources of all that is good. It gives joy, freedom, contentment, inner and outer rest, and peace with all the world. In his mimic land of 'make believe' the child creates a 
world of his own, and begins in play the drama of life, establishing his ideals before he is seized by its grim realities (Hofer, 1897, p. 1).

Play was the underlying idea behind Froebel's work as he created balls, tiles, wooden blocks, and sticks and rings. These items, known as Froebel Gifts or Gaben, demonstrate that children learn by play. The Froebel Foundation USA writes in its philosophy that "play is the engine that drives true learning" and it is purposeful. Many of the gifts represent things from the child's life and children enjoy creating what is familiar. Thus, their knowledge is built upon previous experiences. Froebel's play based curriculum is still employed throughout many preschools.

Elizabeth Palmer Peabody began the first private English speaking kindergarten in Boston in 1859 (Follari, 2007, p. 27; Peltzman, 1998, p. 87). "Peabody's efforts to promote kindergarten as a vocation for American women created a female alternative to the masculine models of professionalism evolving at the same time" (Betty, 1997, p. 61). William Torrey Harris "lowered the school entrance age to provide longer period of education for urban poor" and "combined theory and practice with exposure to the liberal arts in a teacher training program" (Peltzman, 1998, p. 47). G. Stanley Hall enlisted teachers on data collection and encouraged imaginary play (Peltzman, 1998, p. 41).

Granville Stanley Hall began aligning the curriculum with the stages of development (Follari, 2007, p. 28). During this period, Arnold Gesell began his study with impaired children and soon understood that abnormal development would never be fully comprehended without the understanding of normal child development. He noted that development in early childhood is a 
comparable and parallel orderly process (Ames, 1989). The idea of parents and teachers as researchers was first encouraged by Arnold Gesell. His use of film and photographic samples of behavior provided a new view of how children grow and develop (Peltzman, 1998, p. 29). Many of his ideas are observed in early child development which, in turn, are observed in practice at the Gesell Institute of Human Development and the Gesell Developmental Observation (GDO) screening tool. "Arnold Gesell was to the nursery school movement what William Torrey Harris, G. Stanley Hall, and John Dewey were to the kindergarten movement" (Beatty, 1997, p. 145).

Also at the turn of the twentieth century, John Dewey entered education and encouraged the progressive movement of education. He focused on child centered education and learning from experiences and cooperation in his Laboratory School at the University of Chicago. He was known as the intellectual thinker while his friend, Jane Addams, was known as the activist.

Jane Addams played an influential role in focusing on children's health needs. She opened a settlement house, the Hull-House, in 1889, to provide social and educational opportunities for working class people, especially woman. Dewey influenced Addams' philosophy and their shared commitment to the value of democracy and the importance of student experienced education cemented the relationship. Dewey visited the Addams' HullHouse prior to his teaching at the University of Chicago. The Hull-House became a great reference source for the University of Chicago. Dewey was such a fan that he utilized Addams' books in his courses. The women residents fought for social change and established the city's first bathhouse and the first juvenile court in the United States. They lobbied for protective legislation for woman and children, including compulsory education. On the Federal level, they fought for national child labor laws, and many more social causes (Johnson, 2005). Children 
played a special role in the Hull-House. The children engaged in classes in clubs. Jane Addams' fight for child labor laws intensified and consumed much of her attention. In 1904, she helped found the National Child Labor Committee. In describing her, Alexander Rippa (1997, p. 141) wrote,

basic to the philosophy of education that Addams developed during the forty-four years she lived at Hull-House was a vision of society in which all people, regardless of race, gender or socioeconomic status, would have a chance to develop individual talents and interests. She believed that personally enriching experiences for the immigrants were vital in a society based on democracy as a way of life. At the settlement house, she tried to solve the daily problems of new citizens. The result was a human institution in which the immigrants were able to grow and eventually contribute to community affairs.

In 1907, Maria Montessori began her first school based on the premise that students learn best in a prepared environment. The first United States Montessori School was opened in 1915, by Eva McLin. Margaret McMillan designed her environment to not be fully enclosed because of her belief in improving children's health, hence named "open air nursery schools" (Beatty, 1997, p. 134). In 1926, Patty Smith Hill developed the National Committee on Nursery Schools at Columbia Teachers College; presently, it is the National Association for the Education of Young Children (Morrison, 1998). The Project Method was developed by William Heard Kilpatrick which "changed curriculum and classroom activities by providing teachers with clean 
guidelines for organizing and structuring the school day" (Peltzman, 1998, p. 67). Kilpatrick also restructured the classroom from teacher-centered to child-centered (Peltzman, 1998, p. 67). An influential theory, the stages of cognitive development, of how young children think and the overall impact for later learning was developed by Jean Piaget. The four developmental stages in Piaget's theory are sensorimotor, preoperational, concrete operational, and formal operational. His first two stages influence the early childhood years.

Leland Jacobs promoted the use of literature in early childhood settings. He strove to have children appreciate print both in and out of the classroom. In 1986, at the Association for Childhood Education International's keynote address, Jacobs declared that children are our future and deserve "a genuine cultural investment" by educators to ensure their rights, which are "to be playful, to wonder, and to construct and...reconstruct knowledge," are protected (Peltzman, 1998, p. 65).

Lillian Weber strove for classroom organization that facilitated student learning. She also based much of learning on her observation of child-centered, public schools in England in the mid 1960s. "By observing somewhat analogous situations in the industrial cities of England, I sought relevant answers to the problems of present preschool expansion in the United States and to the needs of children in our deteriorated areas of our cities," Weber stated in 1971 (p. 7). Her confidence lay solely in the intelligence of teachers and the ability for all children to learn. Weber (Cohen, 2008, p. 35) said, 
You learn from children where they're at. There's no point in pushing content that doesn't matter to them. If you want to build a curriculum, you must see where it fits. You must connect to each child's history where he or she was before.

In a Harlem public school, in 1967, Weber developed the "Open Corridor Program.” In it, three or four teachers work together to turn their hallway into a shared children's space. This holistic development of the child encouraged the freedom of movement from space to another. Individual and small group instruction replaced whole group. By collaborating in this way, the instructors demonstrated cooperation and created an engaging and dynamic learning community.

The problem arose with implementation, so Weber established an advisory service for teachers implementing open education methods (Ravitch, 1985, p. 242). This was successful and within a few years, the center was conducting summer institutes, publishing a journal, and receiving funding from the federal government and the Ford Foundation. The new method of open education reached the University of North Dakota in 1968. Their New School of Behavioral Studies in Education, instituted by Vito Perrone, focused on sending graduate students to schools as interns while the teachers attend the New School; both were trained in open education. Open education "was perceived as a pedagogical innovation well suited to the age of student disaffection and protest because it stressed participation, freedom, and feelings, while downplaying tradition, authority, and structured teacher" (Ravitch, 1985, p. 248). Commenting on open education, Ewald B. Nyquist, the New York state commissioner of education, stated, "unique opportunities for humanizing and individualizing learning, making it relevant, meaningful and personally satisfying" (Ravitch, 1985, p. 248). 
Grounded in cognitive psychology, Jerome Bruner believed the goal of education was to assist children to develop to their full potential and to experience cognitive and intellectual mastery. Based on previous knowledge, students construct new ideas and concepts. Three modes represent the world for Bruner; they include Enactive (actions-human motor abilities), Iconic (pictures-sensory), and Symbolic (words and numbers-reasoning). These modes are used through interactions and tasks. Bruner believed language to be the most important tool for children. The child plays an active role in the educational process and with the appropriate teaching method, every child can learn (Bruner, 2009). Bruner articulated, "We begin with the hypothesis that any subject can be taught effectively in some intellectually honest form to any child at any state of development" (Perkins, 1992, p. 62).

\section{Early Childhood Education in the United States}

\section{Head Start}

One of the most popular federal programs from Lyndon B. Johnson's "War on Poverty," was Project Head Start. Utilizing federal funds, Head Start was initiated in the 1960s to "help children overcome the cognitive, social, emotional, and physical deficits that frequently accompany growing up in economically deprived homes" (Cotton \& Conklin, 1989).

In 1965, the Office of Economic Opportunity (OEO) spearheaded a grant that established preschool for Mississippi children. The main initiative for the EOE was the Community Action Program (CAP), eventually considered early childhood education and developed Project Head Start in 1965 . The Poverty Czar, Sargent Shriver, was the Director of the poverty program. Shriver sought the advice of Jerome Bruner; in one instance he inquired upon the number of children enrolled in the summer program and Bruner replied that no more than twenty-five hundred children could be accommodated because there were not enough qualified teachers 
(Vinovskis, 2005, p. 74). This advice was disregarded. From 1965-1970, Shriver approved and signed every Head Start grant given in the United States ("Early childhood education: An international encyclopedia," 2007, p. 121).

The program was designed to target "blacks in the poorest and most racially torn state in the Union" (Dittmer, 1994, p. 368). Polly Greenberg (1990, p. 100-103) wrote,

It's the consensus of articulate spokesmen from among the poor, as well as of other "poverty experts" and "education experts" everywhere, that the American system of education at all levels has somehow thus far not been able to effectively educate most poor people, especially Negroes. Negroes often drop out of educational institutions in a vague cloud of embarrassed failure feelings; or in disgust and hostility; or they docilely allow themselves to be "passed along" in the system, learning nothing of meaning to them, and learning a lot about "faking it"" or they adapt themselves to another man's values and come out doing well in his world, abandoning their own, which cries for their leadership. The poor, if they ran schools for their children, would they do the same thing? Would they use their judgement in hiring people who would look out for their interests and promote their values (which might be the same as the values of the middle-class or might be less superficial)? Would they see to it that very great changes were made which might seriously enhance their children's future 
chances economically, occupationally, socially, politically,

psychologically, and in status terms? We guessed yes. We would experiment.

Greenberg was a staff person for the Office of Economic Opportunity and a child development specialist. Through her mother, she knew many of the civil rights leaders in the South. Utilizing this contact, she searched for a group willing to apply for a Head Start grant to be operated by people who believed in equal rights and opportunities for all citizens ( $\mathrm{P}$. Greenberg, 1990). Tom Levin, a previous worker during Freedom Summer, was the founding director of the Mississippi Child Development Group of Mississippi (CDGM). At the time, Levin and Art Thomas were developing "freedom schools." These schools would house civil rights workers' children. While the idea was large, they believed it could be done on a more grandiose scale as Greenberg encouraged. The proposal included a preschool program for seven weeks during the summer. Levin

required the poorest of the poor--not middle-class, 'representatives' of the black race selected by well-meaning liberals in the white world-to organize themselves as the tiny crossroads community's 'school board', find and fix a facility, sign up eligible children by name and address, and hire potential staff, if the locality chose to be a part of CDGM's grant application. No grant was guaranteed (P. Greenberg, 1990). 
CDGM and the War on Poverty were greatly opposed by Mississippi's white establishment (Dittmer, 1994, p. 370). Incidents that included shootings into center, school boards refusing to rent their buildings and buses to Head Start, the Klu Klux Klan burning a cross at a center, and owners in Anguilla refusing to permit sharecroppers' children to enroll in the program, did not deter the Head Start centers opening. The battles the centers faced were not only with the community members but also with political leaders.

CDGM's design was a pioneer Head Start program. The children received medical care, meals, basic concepts, a "living arts" component, and creative activities. John Dittmer (1994, p. 373) wrote,

The first CDGM was a success. It did offer a "head start" to several thousand preschool children, all but a handful of them black. CDGM also provided meaningful jobs for 1,100 women and men in these communities. Where the going wage for plantation labor was three dollars a day, teacher's aides and trainees were paid from fifty to sixty dollars a week.

When the third grant ran out in 1967, CDGM "dissolved as an administrative entity" (Dittmer, 1994, p. 382) and contracted with Mary Holmes Junior College, the original CDGM sponsor. Head Start continues today and President George W. Bush signed Public Law 110-134 "Improving Head Start for School Readiness Act of 2007" on December 12, 2007, reauthorizing the Head Start program with revisions, until September 30, 2012. As expressed in the Head Start Act, the purpose of the Head Start program is "to promote school readiness by enhancing 
the social and cognitive development of low-income children and their families, through the provision of health, educational, nutritional, social, and other services that are determined, based on family needs assessments, to be necessary" ("Improving Head Start for School Readiness Act," 2007).

Head Start has endured many critics over the past forty years. It has also had many supporters. Since the late 1970s and early 1980s, studies have "shown that Head Start and Head Start-like experimental preschools have potentially lasting long-term effects" (Beatty, 1997, p. 199; Gammage, 2006, p. 239; Kagan \& Cohen, 1996, p. 58). The controversy lies in the fact that if similar educational tactics are not encouraged throughout a child's schooling, the effects have the probability to be negative. Also, the success of the overall family is a positive effect which is not easily measured.

In the 2006-2007 program year, 976,150 children were served by Head Start. Approximately 7, 610 of those children resided in West Virginia. In West Virginia, the cost per child in 2005 was around $\$ 6600$ (US Department of Health and Human Services, Administration for Children and Families, Administration on Children, Youth and Families, and Head Start Bureau, 2005). In 2008, Head Start spent approximately \$6.2 billion (National Head Start Association, 2007).

\section{West Virginia's Universal Access to a Quality Early Education System (2525) Defined}

West Virginia's Universal Access to a Quality Early Education System (2525) is a policy designed to achieve the highest standards by employing high quality universal preschool programs by the 2012-2013 school year. This policy was unanimously approved on January 9 , 2003, and became effective February 12, 2003. Effective July 2004, only 3-year-olds with a documented disability are eligible to participate in the Public School Early Childhood Education 
initiative (National Institute for Early Childhood Research, 2007, p. 146). On July 15, 2005, the policy was revised and adopted by the West Virginia Board of Education, thus becoming effective on August 14, 2005. As of today, Policy 2525 is to be implemented in all public school programs, by 2012-2013, in all 55 counties in West Virginia.

In 2007, West Virginia enrolled forty-five and eight tenths percent (45.8\%) of 4-year-olds (National Institute for Early Childhood Research, 2007, p. 15) in public schools, child care centers, Head Start, or faith based centers. No matter the center, each must offer a minimum of sixteen hours per week and a maximum of twenty-eight hours per week during the school year calendar for no less than one hundred and eight instructional days (West Virginia Board of Education, 2006-2007). Policy 2525 covers all organizations associated with the public school system, including but not limited to Head Start and community child care centers. Each County is responsible for submitting a plan to the state to explain how it will expand access to preschool. 
The following Table 1 reports some basic statistics on child care in West Virginia.

Table 1

Child care in West Virginia

Child Care

Annual fee paid for full-time center care for 4 year old (average)

Annual fee paid for full-time care for a 4 year old in a family child-care home (average)

Median annual family income of marriedcouple families with children under 18 (average)

Number of families served

Number of children served

Number of child care providers participating

Percent of subsidized children cared for in licensed centers/homes

Percent of subsidized children care for by relatives

Percent of subsidized children cared for in other non-regulated care

Number of centers

Accredited centers

Number of family child care home

Accredited child care homes

Percent requests for pre-school age care

\section{West Virginia}

$\$ 4,560$

$\$ 3,600$

$\$ 57,253$

5,600

9,300

3,104

$97 \%$

$1 \%$

$2 \%$

296

32

2,438

7

$39 \%$

Source: NACCRA and WV Child Care Resources and Referral Network. (2008). 2008 Child care in the state of: West Virginia. Retrieved October 1, 2008, from http://www.earlychildhoodfocus.net/randd/data/docs/WV.pdf. 
The state policy encompasses a broad range of requirements, including, but not limited to:

1) lead teachers must hold at least a BA,

2) lead teachers must have specialized training in preschool area,

3) assistant teachers must have a CDA or equivalent,

4) teachers must receive at least 15 hours per year of in-service,

5) classrooms must not exceed 20 children,

6) the teacher-student ratio must not exceed 1:10,

7) screenings and referrals for vision, hearing, and health must be required,

8) at least one meal must be required daily, and

9) site visits are ongoing to ensure adherence to state program standards

(National Institute for Early Childhood Research, 2007, p. 29).

Creative Curriculum is utilized in the majority of West Virginia preschool classrooms. Teachers attend a training session and are provided a handbook with ideas regarding the classroom. A portfolio and an online Creative Curriculum assessment tool are employed to allow for ease in entering continuous assessment information and sharing it with families and administrators. This allows teachers to get a glance at children's progress or at a specific goal they are monitoring. Policy 2525 requires two home visits or parent conferences during the school year.

The implementation aim is to provide consistency and quality among all West Virginia preschool classrooms. 
Why Preschool?

\section{Working Mothers}

Society has gone from a traditional family hierarchy where the fathers continue working while the mothers stay home (Gammage, 2006, p. 241; Kagan \& Cohen, 1996, p. 9) "becoming homemakers and consumers rather than producers" (Beatty, 1997, p. 2), to a society where "in 2008, women will make up about forty-eight percent of the labor force and men fifty-two percent" ("Women's share of labor force to edge higher by 2008," 2000). While many women are choosing to enter the work force, many are required to because " $28 \%$ of all children were living with a single parent" (Zigler, Gilliam, \& Jones, 2006, p. 4), many of which are women. As the head of the single parent homes (Kagan \& Cohen, 1996, p. 12), women are responsible for providing an income for the family. In addition, full time early childhood education is more likely to be required with children under the age of five than with households with older children (C. Kent et al., 2005, p. 21). A similar trend was seen during World War II and the Great Depression when women were forced into the workforce. At that time, children were placed into child care facilities, which were closed once the war ended.

The change in the workforce necessitates a safe, educational place for children while their parent or parents work (O. A. Barbarin et al., 2006; Kagan \& Cohen, 1996, p. 5; Zigler, Gilliam, \& Jones, 2006, p. 70). The ideal setting in a preschool classroom is one in which students will learn literacy, language, math, science, social studies, creativity, social and emotional development, and health and physical development. They should also learn about inquiry, curiosity, choice, relationships, creative thinking, exploration, and the art of questioning. 


\section{Poverty}

While attending the National Center for Children in Poverty (NCCP) meeting, Jean Layzer (O. Barbarin et al., 2006), from ABT Associates, stated, "High quality early learning is like a 'life jacket' for low-income kids. They need the life-preserver; whereas middle and upperincome kids already know how to swim and are not dependent on this to get ahead.” Poverty affects approximately 4.1 million infants, toddlers and preschoolers in the United States in 2005 (US Census Bureau \& Housing and Household Economic Statistics Division, 2005). For a family of four, in West Virginia, "poverty" means that total income was less than $\$ 21,200$, with many families falling well below that amount (University, 2008). Poverty and the stressors surrounding poverty can influence the development of children, which may result in poor outcomes later in life (Duncan et al., 2007; Perez-Johnson \& Maynard, 2007, p. 589). Economic stress indicates that children will be less successful in school and as adults in the labor market, have poorer health, and be more likely to commit crimes and engage in other forms of problem behavior (Heckman, 2006; Holzer, Schanzenbach, Duncan, \& Ludwig, 2007; "Preventing crime with pre-kindergarten: A critical investment in West Virginia's safety," 2006).

In and of itself, poverty does not indicate these long-range problems; however, other factors often associated with poverty, such as inadequate nutrition, insufficient academic oriented home environments, limited or poor prenatal care, inappropriate health care, and unsafe home environments, may suggest these problems in the future.. Undoubtedly, poverty greatly influences this critical period of early childhood development and low-income children often show positive gains when engaged in high-quality preschool programs, (Duncan et al., 2007, p. 143; L. Klein \& Knitzer, 2006, p. 8) indicating a linear correlation between poverty and 
educational outcomes. Even if early childhood programs impact only a small number of children in poverty, that is beneficial.

\section{Development}

"We know the brain develops more in the first five years of life than at any other time," said Cathy Jones, early childhood coordinator for the West Virginia Department of Education. Research confirms that the brain is only about $25 \%$ complete at birth. The development of the remaining $75 \%$ is influenced by the experiences in which children engage, especially during the early years. "Pre-k is a time for enormous acquisition of knowledge, when children develop a sense of right and wrong or good and bad. Without a good foundation, we spend the rest of their education trying to repair the damage" (WV Department of Education, 2007). During this (early childhood) time period, teachers can develop a baseline for each child and utilize it to enhance their natural development.

With tougher academic standards, children's play is being limited, even though play both stimulates and influences the nerve cell connections. Therefore, the absence of play deters healthy and creative individuals (Isenberg \& Quisenberry, 2002). Maria Montessori deemed play as the work of the child. Montessori believed play influences the development of fine and gross motor skills, language, socialization, personal awareness, emotional well-being, creativity, problem solving and learning ability, with which researchers today agree. The Association for Childhood Education International (ACEI) "believes that play is a dynamic, active, and constructive behavior which is an essential and integral part of all children's healthy growth, development, and learning across all ages, domains, and cultures" (Isenberg \& Quisenberry, 2002). Play is a time for children to process and attach meaning to new information. 


\section{Societal Issues}

A good preschool program has the potential to improve society in several meaningful ways. First, research shows that high quality preschool improves a child's overall performance with regard to high school graduation, college attendance rates, lower reliance on welfare, and lower rates of criminal activity (Beatty, 1997, p. 202; Belfield, 2006). It is reported that “participants in Oklahoma's universal program...report strong academic gains (of 16\%) in overall language and cognitive skills tests" (Gormley \& Phillips, 2003, p. 4). Second, it deters unhealthy behaviors like smoking and drug use and the requirements of immunizations and health check-ups and the emphasis on nutrition enhance the overall health of the students (Belfield, 2006). Finally, it is predicted that public spending will decrease if preschool programs reduce grade repetition and the need for special education.

\section{Teacher Preparation}

A significant component of the success of early childhood lies in teacher training and professional development. This is the area which fluctuates the most in the United States, because of training variations across states, particularly with those facilities remaining exempt from licensing.

These variations in training for early childhood teaching have been recognized and possible solutions have been identified; yet, the challenge remains significant (S. L. Kagan \& Cohen, 1996, p. 125). Traditionally, early childhood positions have been gender biased, assuming that women were the only gender qualified, leaving the profession with historically inadequate pay due to gender inequity. The foundational qualities for early childhood positions has historically been maternal and instinctive based, rather than teacher education or preparation based. The low salary range has left many educators searching for other employment 
opportunities with higher pay and more stability. This has resulted in a high turnover rate (Gammage, 2006, p. 241; Horm-Wingerd, Hyson, \& Karp, 2000; Neugebauer, 2008, p. 26) and inexperienced teachers teaching young children.

We are learning that closing the achievement gap depends greatly on providing teachers with the professional development and supports that can help them more effectively promote early literacy and early math in the context of nurturing and emotionally supportive classrooms. Designing and allocating resources for these infrastructure supports poses new challenges and opportunities for policymakers and administrators that need to be part of the public dialogue about improving access to and the quality of preschool learning (L. Klein \& Knitzer, 2006, p. 13).

While some higher education institutions have available specialized preschool certification programs, many do not. "All 50 states require kindergarten teachers to have a minimum of a bachelor's (BA) degree, and some states also require endorsements or certifications that are specifically related to the early childhood field" (Ackerman, 2004, p. 3). Of the states that offer state-financed preschool, however, slightly more than half require teachers in the programs to have a bachelor's degree in early childhood or another subject (National Center for Early Development \& Learning, 2001). Surveys of preschool teachers show that while $87 \%$ of preschool teachers in public schools have a bachelor's degree or higher, only $30 \%$ of teachers in Head Start programs and 39\% of teachers in for-profit centers have a 
bachelor's degree (Saluja, Early, \& Clifford, 2002). The National Association for the Education of Young Children (NAEYC), National Council for Accreditation of Teacher Education (NCATE), and the National Research Council (NRC) recommend that teachers hold a four-year college degree and specialized training in early childhood. Barnett $(2004$, p. 1) summarized that child development outcomes are higher when teachers hold bachelor's degrees

The most effective preschool teachers have a minimum of a fouryear degree as well as specialized training in early childhood...Preschool programs employing teachers with fouryear college degrees have been shown to be highly effective and good economic investments... Low educational qualifications and a lack of specific preparation in preschool limit the educational effectiveness of many preschool teachers. Better compensation is required to hire and retain more effective teachers.

With the increase in preschool classrooms, there has also been an increased interest in the question regarding the qualifications a teacher must have to successfully teach in a preschool classroom that promotes positive outcomes for children. Howes, Burchinal, Pianta, and Bryant (2008) of the National Center for Early Development and Learning indicate that "children made (make) academic gains in classrooms where the teacher engaged them in interactions that encouraged communication and reasoning, was sensitive and responsive in her/his interactions with children, and constructed an atmosphere of respect, encouragement, and enthusiasm for learning." They further point out that such a teacher does not necessarily have a bachelor's 
degree. Quality early childhood teachers should engage in "both early childhood content and pedagogy" (American Association of Colleges for Teacher Education (AACTE) Focus Council on Early Childhood Education2004, p. 7). This movement toward improved training will also reduce the notion of early childhood teachers as caregivers and augment the professionalization of the field (Cochran-Smith, 2005; L. Klein \& Knitzer, 2006, p. 19; Neugebauer, 2008, p. 26).

With regard to training, North Carolina implemented a licensure program that includes three strands: child development, early childhood education, and early childhood special education (Myers, Griffin, Telekei, Taylor, \& Wheeler, 1998, p. 1). New Jersey's program emphasizes four general areas (Lobman, Ryan, \& McLuaghlin, 2005). First, teachers focus on the foundations of early childhood. Second, teachers understand the pedagogy of teaching young children literacy, math, social studies, science, and the arts. Third, teachers apply this knowledge in planning, assessing, and adapting instruction to meet individual children. Finally, pre-service teachers engage in direct experience with young children. New Jersey's approach has been influenced by the decision in Abbott v. Burke ("Abbott v Burke IV," 1998; "Abbott v Burke VI," 2000). This New Jersey Supreme Court decision ruled on preschool teacher certification and preparation. The ruling required:

- Rigorous content standards-based education, supported by per-pupil funding equal to spending in successful suburban schools

- Universal, well-planned and high quality preschool education for all 3 and 4 year olds

- Supplemental ("at-risk") programs to address student and school needs attributed to highpoverty, including intensive early literacy, small class size and social and health services

- New and rehabilitated facilities to adequately house all programs, relieve overcrowding, and eliminate health and safety violations 
- School and district reforms to improve curriculum and instruction, and for effective and efficient use of funds to enable students to achieve state standards

- State accountability for effective and timely implementation, and to ensure progress in improving student achievement (Abbott v Burke, "Abbott v Burke IV," 1998; Abbott v Burke, "Abbott v Burke V," 1997)

Specifically, the decision required that the thirty poorest districts, also known as Abbott districts, were to create high-quality preschool classrooms for all 3 and 4-year-olds beginning 1999-2000. Preschool classrooms were to be limited to 15 children and staffed by a state certified teacher and assistant who followed a developmentally appropriate curriculum aligned with the NJ Core Curriculum Content Standards. The court also ruled that state-funded preschool classrooms had to have a teacher with a bachelor's degree plus a specialized training in early childhood education (Education Law Center, 2007; Lobman et al., 2005).

This decision created an abrupt change in teacher preparation and preschool classrooms in New Jersey. This New Jersey court's decisions and state movements place responsibility partially on higher education to prepare teachers. In order to be effective, licensure programs must meet state regulations and National Council for Accreditation of Teacher Education (NCATE) program approval standards. Fortunately for teachers, as the percentage of preschool enrollees in a school increases, "teachers report higher job satisfaction, lower turnover and absenteeism, and they are less likely to report 'student behavior interferes with my teaching", (Belfield, 2006, p. 9) in the later classrooms. While providing licensure opportunities for undergraduate students is easier, the question becomes what to do with teachers who already hold certification in either preschool special needs or preschool licensures. 
Research also indicates that optimal learning and development occurs when teachers are professionally qualified (Barnett, 2004, p. 2; Bogard, Traylor, \& Takanishi, 2008, p. 1). However, the validity of this point has been rebutted by Early et al., (2006) due to the variance in early childhood education and certification programs. Student teaching experiences are also as variable as the requirements for certification, and the quality of a teacher's preparation is often related to the risk status of the students being served (L Darling-Hammond, 2006). Certification requirements vary from state to state, primarily due to the fact that early childhood is an add-on certification. Pay is often tremendously lower than their counterparts. In a study focusing on programs that develop teachers' cultural competencies, only a handful were model programs which infused coursework and practical experiences throughout their program to provide teachers with the knowledge and skills they needed to work with diverse students (Lim \& AbleBoone, 2006). For example, "Early and Winton (2001) found that only $43 \%$ require at least one course in working with culturally and ethnically diverse children" (Bogard et al., 2008). Early et al (2007, p. 577) writes, "teachers do not work in a vacuum but instead are part of a larger educational system" thus influencing teaching strategies and student result.

To get from teacher education to impact on pupils' learning requires a chain of evidence with several critical links: empirical evidence demonstrating the link between teacher preparation programs and teacher candidates' learning, empirical evidence demonstrating the link between teacher candidates' learning and their practices in actual classrooms, and empirical evidence demonstrating the link between graduates' practices and what and 
how much their pupils learn. Individually, each of these links is complex and challenging to estimate. When they are combined, the challenges are multiplied: There are often substantial time lags between the teacher preparation period and the eventual measures of pupils' achievement or other outcomes; there are many confounding and intervening variables (which themselves are difficult to measure) that influence what teachers are able to do and what their pupils learn; and the sites where candidates complete fieldwork and eventually teach are quite different from one another in context, school culture, resources, students, and communities (Cochran-Smith, 2005, p. 303 as found in Bogard et al, 2008, p. 3).

\section{Preschool as a Right}

Children have the right to an education and they have a right to more than just custodial care. The question from the opposition to preschool as a right often becomes, when does this right begin? First, disadvantaged children are provided the right to attend school via state and federal government mandates. "As Patty Smith Hill asks, 'should little children always be last in line?"” (Beatty, 1997, p. 203). Second, higher income families are able to provide their children with higher-quality preschools than lower or middle income families (S. L. Kagan \& Cohen, 1996, p. 59). Finally, middle income families are caught in the middle. They are not able to afford the high quality preschools, but they are also unable to access a public subsidy. 


\section{Characteristics of High Quality Preschool Programs}

\section{Curriculum}

Globally, France, Sweden, England, Scotland, New Zealand, and Norway have constructed national preschool curriculums. This is not the case in the United States, though recommendations from the National Association for the Education of Young Children (NAEYC) have been developed and encouraged.

A developmentally appropriate preschool curriculum will encourage and foster a relationship between a rich environment and play, which is how young children construct meaning out of their world (Chen, Horsch, DeMoss, \& Wagner, 2004, p. 35). Klein \& Knitzer (2006, p. 15-19) recommend a research based curriculum that emphasizes teachers' active engagement with the children, including social and regulatory skills, responsiveness to cultural diversity and English language learners, and requiring new ways to define and measure classroom quality, teacher effectiveness, and student progress, based on the NAEYC and the National Association of Early Childhood Specialists in State Departments of Education (NAECS/SDE) joint position statements.

The children's work needs to be practical and purposeful. An age appropriate and individually appropriate classroom filled with learning centers that include sand and water, blocks, literacy, puzzles, writing materials, dramatic play, creative art, and science will cultivate knowledge. Curriculum is to be a work in progress, never an absolute (Jalongo et al., 2004, p. 145), continuously reflecting the children and their families. Long term work, whether an intensive week or a lengthy school year project, is to be encouraged and should be childcentered. Time is permitted for children to gain socially-constructed knowledge as well as solitary learning, all the while encouraging process over product. 


\section{Assessment}

In conjunction with the curriculum lays assessment. As revealed in Italian history the "documentation and discussion (conversations characterized by debate and negotiation)-in which teachers observe, record, share, analyze, and debate their emerging understandings of children's ways of thinking and learning and then share these understandings with others" (New, 2007, p. 7) is critical in assessment. Documentation displays a teacher's understanding of student learning and also reflects teacher practices. Teachers' observations of children's development are modeled in teaching children refined observation skills, as children are an active subject for assessment.

When teachers engage in different types of assessment, it results in a better overall understanding of the child. There is a broad range of developmentally appropriate preschool assessments that include portfolios, work samples, videos, photographs, rubrics, and anecdotal notes. Teachers are to review these samples periodically in order to gain an understanding of student comprehension, to assess their own teaching strategies, and to maneuver their strategies to enhance student understanding. Unlimited access to the documentation and the opportunity to choose assessment methods, when appropriate, are to be granted to students. Lastly, this documentation is to be available for family members to examine at anytime. A journey of learning should unfold through the documentation and assessment of a child.

\section{Student-teacher Ratio}

According to the NAEYC criteria (NAEYC, 2005), preschool classrooms should have up to twenty children and there should be two teachers in the room at all times. Ratio has a direct impact upon the amount of time and observation a teacher is permitted to spend with students (R. Pianta et al., 2005, p. 147). Although the research is not exact, intuitively, the rationale is 
that teachers will have more time to spend with students resulting in a higher performance level. When ratios are lower, child outcomes are better. Textor $(1998$, p. 168) notes that the quality of interaction decreases as the ratios increase. One of the problems lies in funding, when teacher to student ratios are lower this results in more teachers being hired (Clifford et al., 2005, p. 128). In terms of accreditation, ratio, fortunately, is easily measured and recognized as an indicator of quality (S. L. Kagan \& Cohen, 1996, p. 67).

\section{Environment}

Maria Montessori wrote, "Education is a natural process spontaneously carried out by the human individual, and is acquired not by listening to words but by experiences upon the environment." Ultimately, the children's environment, space and materials, should flow easily from the home-life into the classroom (Jalongo et al., 2004, p. 144) for the optimum development. The Reggio Emilia approach views the environment as the third teacher, from which children perceive and create meaning (Strong-Wilson \& Ellis, 2007, p. 41). Home-like areas for meals, nap, reading and dramatic play should be reflected in the environment. In addition, science and movement should be incorporated to enhance cognitive and social development (Read, 2007, p. 387). As we know, "children are highly impacted by their experiences of place" (Read, 2007, p. 388). A "delicate balance" is encouraged in the Reggio Emilia approach between providing structure and encouraging children's free exploration (Strong-Wilson \& Ellis, 2007, p. 41).

Montessori relishes the use of the outdoor environment, as does Reggio Emilia; in the words of Froebel, "to make the inner outer" (Li, 2006, p. 37). Montessori believes the outside garden is to be used as part of the classroom, not as a special privilege. Preferably, the outside area will have shelter so the children may play, dine, or sleep under, no matter the weather. 
While studying the Reggio Emilia approach, Moore (Strong-Wilson \& Ellis, 2007, p. 43), "concluded that exploration of the natural environment intensifies friendships, just as friendships prompt exploration of the environment."

Because Montessori believed the learning environment to be critical, she incorporated child-sized tables and chairs that are light enough for children to move around the room. In addition, small carpets are available for children to place on the floor and resume work. Montessori believed that children are more successful when they were left to develop naturally, in a space appropriate for them.

Parents, family members, community members and students alike should feel welcome in the classroom. The classrooms should be aesthetically pleasing, from the colors to the textures and the design. The work of the child should be the focus on the walls; this creates an environment that is student owned. Thus, the environment is to be maximized to its full potential.

While Montessori and Reggio Emilia are based in Italy, the United States should place the same emphasis on environment. Environment is where children develop relationships, discover a sense of community, and experience active learning; it is of the utmost importance.

The environment also includes the students and teachers within. Respect plays a tremendous role in the environment. Miller \& Pedro (2006, p. 294) noted "the teacher's role is imperative to successful teacher student interaction and creating a positive classroom climate." While many behaviors are brought into the classroom by children, it is the calling for the teacher to mold and shape the proper behaviors (Miller \& Pedro, 2006, p. 294). This reciprocal arrangement conveys worth and value to both the student and the teacher. 


\section{Conclusion}

In closing, this literature review reinforces the need for preschool education that is held accountable to meet physical, emotional, social and cognitive needs of all children and of all families (Jalongo et al., 2004, p. 144). It is a battle that many must engage in with an infinite amount of early childhood history. Understanding where early childhood originated and the theories that define it will make one more appreciative and understanding of the road forged by many before us.

For this study, I examined the goals of early childhood education in West Virginia, specifically West Virginia’s Policy (2525) Universal Access to a Quality Early Education, and how its implementation is perceived in several counties by different people in different roles. This brief review of West Virginia preschool education will provide readers a better understanding of where West Virginia early childhood education originated. The comprehension of other states' histories and implementation regarding universal access to early childhood education may influence its success or failure in West Virginia. 


\section{CHAPTER 3: METHODOLOGY}

\section{Introduction}

The literature review, personal experiences, and recognition of the breadth of research in early childhood education, especially preschool education, and school readiness in recent years, undergirds this investigation, the goal of which is to study and contribute to the larger literature by examining the impact of early childhood education on a small segment of West Virginia. The intention is not to generate findings that can be generalized to a larger population, but rather to develop a better understanding of the phenomenon of preschool education in one of the poorest states in the country, which happens to be the only state that is entirely within Appalachia, and a state that is relatively new to the implementation of public preschool.

This chapter describes the design of this qualitative study which is based on discourse analysis; including the rationale for methodological choices, sampling criteria, procedures, data collection methods, and instruments. Included in this chapter is a description of participants, research design, procedures, research instruments, data collection methods, and a timeline. Although the ability to generalize is limited by the nature of the methods, the policy implication extends beyond the boundaries of the state and the study, to impact conversation about the nature and policy of early childhood education.

\section{Rationale}

Discourse analysis is a method of approaching and thinking about a problem; it is neither a qualitative nor a quantitative research method; instead, it is an approach of questioning the basic assumptions of quantitative and qualitative research methods. A qualitative study better provides an "understanding of a situation that would otherwise be enigmatic or confusing" (Eisner, 1991, p. 58); specifically for this study, it clarifies the goals of Policy 2525. Discourse 
"refers to the whole process of social interaction of which a text is just a part," according to Fairclough (1989, p. 24).

If choosing a quantitative method, placing a numerical value would not provide the relationship or interaction with the world (Merriam, 2002, p. 3) by the children, the teachers, or the school environment. Discourse analysis will not provide a tangible answer to problems based on scientific research. The goal is to reveal hidden motivations behind a text, in this case Policy 2525, or behind the choice of a particular method of research to interpret that text. Using discourse analysis will provide absolute answers to a specific problem, enable us to understand the conditions behind that specific "problem," make us realize that the essence of that "problem" and its resolution lie in its assumptions, which are the very assumptions that enable the existence of that "problem." By enabling us to make assumptions explicit, discourse analysis enables us to see the problem from a higher position and to gain a comprehensive view. It allows the researcher to intertwine research questions developed through a comprehensive literature review with assumptions from enacted policy. Discourse analysis is meant to provide a higher awareness of the hidden motivations in others and ourselves and, thus enable us to solve concrete problems, not by providing unequivocal answers, but by making researchers ask ontological and epistemological questions. Those questions form the basic conversation between the researcher and the subjects who must interpret, enact, and live this policy.

Discourse analysis does not provide a particular view of the world, other than there is no one true view or interpretation of the world. It indicates that the world is inherently fragmented and heterogeneous, and any sense-making system or belief is subjective interpretationconditioned by its social context and dominant discourse. Concurrently, when critically evaluating text, researchers should focus on the critical nature of the discourse and context of the 
document (Luke, 2008). There are also specific questions that are addressed: "How is the text positioned or positioning? Whose interests are served by this positioning? Whose interests are negated? What are the consequences of this positioning?" (Janks, 1997, p. 324).

Thus, discourse analysis is the application of critical thought to social situations and their discourses. There are no specific guidelines to follow in discourse analysis since it is basically an interpretative and deconstruction of readings. In this research, the guidelines will be determined by the research questions, which in turn have been undergirded by the extensive literature review on early childhood education. Again, the purpose of discourse analysis is not to provide finite answers, but to expand policy interpretations, thus making researchers and practitioners realize their own, and others, limitations and motivations.

There are many approaches to discourse analysis according to Gee (2005, p. xii), who wrote

we are creatures of language....there is an imbalance in human communication: each human being creates complex meanings in language, but each of us is so good at finding meanings that we are often too quick to attribute meanings to others that are rooted more in our own cultures, identities, and fears than they are on a close inspection of what the other person has said or written...In the end, discourse analysis is one way to engage in a very important human task. The task is this: to think more deeply about the meanings we give people's words so as to make ourselves better, more humane people and the world a better, more humane place. While we still 
may disagree with others after reflection, we will, nonetheless, be in a position to be a much better critic, to represent what we believe in a much better way. But we may also sometimes change our own viewpoints to be more positively inclined toward others than we were initially.

With this being said, I rely on James Gee's language-context analysis (Gee, 2005, p. 54). This analysis takes into account that the written word has situated meaning based on the setting involved. Thus, situated meaning is associated with a cultural model. The research will also be based on Gee's (2005, p. 83) models-in-(inter)action, or what guides our actions and interactions within the world, specifically the early childhood environment.

The early childhood institution is shaped around language, whether written or spoken, which they render meaningful (Gee, 2005, p. 1). Policy 2525 generates specific meaning encased within the context of the policy and the cultural group that reads, interprets, and implements it.

\section{Research Questions}

My objective in conducting this qualitative study is to enhance my understanding of West Virginia's Universal Access to a Quality Early Education System (2525) across a small segment of the state's academic population.

The research questions are as follows:

1. How do participants' define their roles in the implementation of universal preschool education in West Virginia? 
2. What are participants' understandings of the goals of universal preschool education in West Virginia?

3. What are participants' perspectives of the benefits and challenges of universal preschool education in West Virginia?

4. How is universal preschool being implemented in West Virginia?

5. How does the enacted policy compare to the legislated intent of the policy?

Question number two is my primary question and focus of the study. This question guides the overall understanding of entire research project. By comprehending the goals of Policy 2525 , I will be able to further investigate its implementation. The first, third, fourth, and fifth question are considered secondary to the study. Those questions will give an appreciation for the execution of Policy 2525.

\section{Research Design and Layout}

This is a discourse analysis research study. Specifically, symbolic interaction will be utilized for the study, based on the premise that there is a shared meaning through interactions (Patton, 2002, p. 112). The thirteen interviews will attempt to provide a richer, deeper understanding of West Virginia's Universal Access to a Quality Early Education System (2525). This group will provide several different perspectives across different levels of administration within the school structure.

While looking for discourse within the study, a discrepancy model evolves. A comparison will be made based on the standard (S), Policy 2525, and the performance (P), actual occurrences in the classroom. In this discrepancy evaluation model (DEM) outlined by Steinmetz (1983, p. 80), when engaged in a comparison, a discrepancy (D) yields. This model can be viewed in figure 2 . 
Figure 2

\section{Discrepancy Evaluation Model (DEM)}

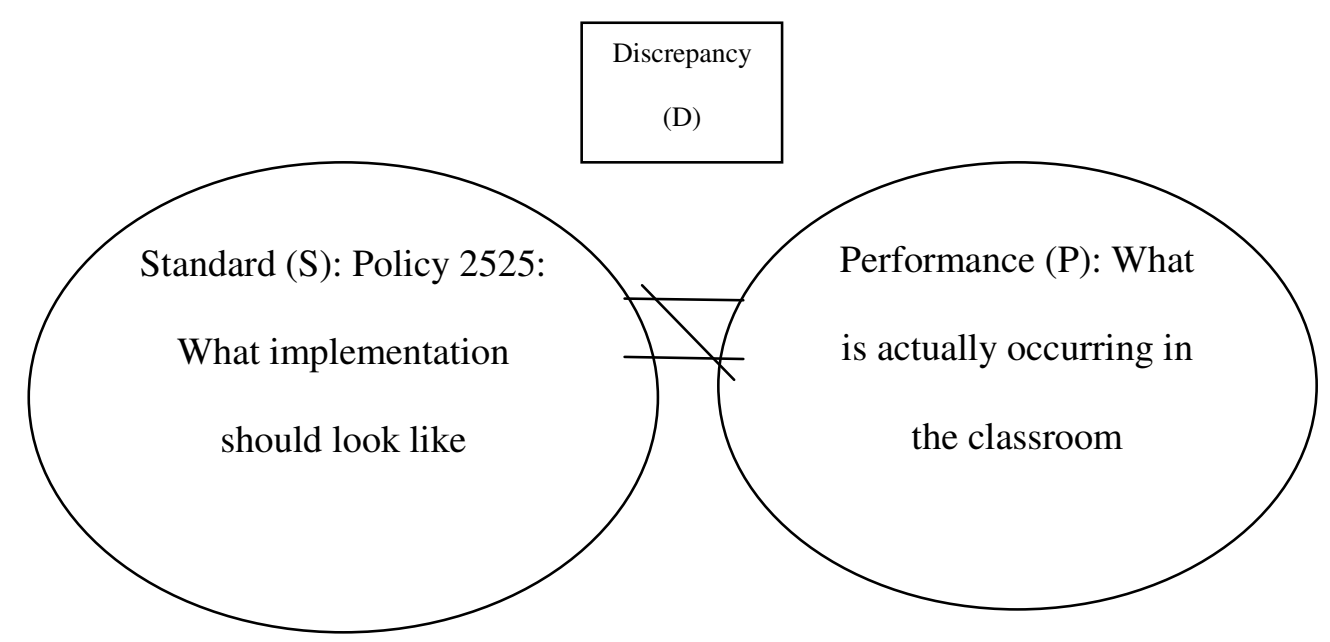


In figure 3, the work plan is presented.

Figure 3

Elements of an evaluation work plan

\begin{tabular}{|c|c|c|c|c|}
\hline Question & Standard & $\begin{array}{c}\text { Source of } \\
\text { Information }\end{array}$ & Instrument & Data Collection \\
\hline $\begin{array}{l}\text { What are } \\
\text { participants' } \\
\text { understandings } \\
\text { of the goals of } \\
\text { universal } \\
\text { preschool } \\
\text { education in } \\
\text { West Virginia? }\end{array}$ & $\begin{array}{l}\text { Policy } 2525 \\
\text { Elements }\end{array}$ & $\begin{array}{l}\text { Early childhood } \\
\text { state coordinator, } \\
\text { early childhood } \\
\text { county } \\
\text { coordinator, } \\
\text { elementary } \\
\text { school principal, } \\
\text { early childhood } \\
\text { certified teacher }\end{array}$ & Interview & Researcher \\
\hline $\begin{array}{l}\text { What are } \\
\text { participants' } \\
\text { perspectives of } \\
\text { the benefits and } \\
\text { challenges of } \\
\text { universal } \\
\text { preschool } \\
\text { education in } \\
\text { West Virginia? }\end{array}$ & $\begin{array}{l}\text { Policy } 2525 \\
\text { Elements }\end{array}$ & $\begin{array}{l}\text { Early childhood } \\
\text { state coordinator, } \\
\text { early childhood } \\
\text { county } \\
\text { coordinator, } \\
\text { elementary } \\
\text { school principal, } \\
\text { early childhood } \\
\text { certified teacher }\end{array}$ & Interview & Researcher \\
\hline $\begin{array}{l}\text { How do } \\
\text { participants' } \\
\text { define their roles } \\
\text { in the } \\
\text { implementation } \\
\text { of universal } \\
\text { preschool } \\
\text { education in } \\
\text { West Virginia? }\end{array}$ & $\begin{array}{l}\text { Policy } 2525 \\
\text { Elements }\end{array}$ & $\begin{array}{l}\text { Early childhood } \\
\text { state coordinator, } \\
\text { early childhood } \\
\text { county } \\
\text { coordinator, } \\
\text { elementary } \\
\text { school principal, } \\
\text { early childhood } \\
\text { certified teacher }\end{array}$ & Interview & Researcher \\
\hline
\end{tabular}




\begin{tabular}{|c|c|c|c|c|}
\hline $\begin{array}{l}\text { How is universal } \\
\text { preschool being } \\
\text { implemented in } \\
\text { West Virginia? }\end{array}$ & $\begin{array}{l}\text { Policy } 2525 \\
\text { Elements }\end{array}$ & $\begin{array}{l}\text { Early childhood } \\
\text { state coordinator, } \\
\text { early childhood } \\
\text { county } \\
\text { coordinator, } \\
\text { elementary } \\
\text { school principal, } \\
\text { early childhood } \\
\text { certified teacher }\end{array}$ & Interview & Researcher \\
\hline $\begin{array}{l}\text { How does the } \\
\text { enacted policy } \\
\text { compare to the } \\
\text { legislated intent } \\
\text { of the policy? }\end{array}$ & $\begin{array}{l}\text { Policy } 2525 \\
\text { Elements }\end{array}$ & $\begin{array}{l}\text { Early childhood } \\
\text { state coordinator, } \\
\text { early childhood } \\
\text { county } \\
\text { coordinator, } \\
\text { elementary } \\
\text { school principal, } \\
\text { early childhood } \\
\text { certified teacher }\end{array}$ & Interview & Researcher \\
\hline
\end{tabular}


A brief timeline in Table 2 is displayed to show the reader the remaining progression of

the study.

Table 2

Timeline of Dissertation Progress

Date

December 2008

January 2009

March 2009

May 2009

July 2009

\section{Action}

Apply for IRB approval for qualitative dissertation study

Contact early childhood state coordinator, early childhood county coordinator, elementary principal, and certified early childhood teacher

Conduct interviews

Transcribe interviews

Begin coding interviews

Complete coding interviews

Defend dissertation 


\section{Policy Document}

Policy 2525 was the first point referenced. The policy was treated as a framework to gain a more in-depth understanding of West Virginia universal preschool. It provided a crossreference for educational jargon, specific notations, and the development of the policy. Examining the policy as well as the perspective of West Virginia educators allows for a comparative analysis of the similarities and differences (Pini \& Gorostiaga, 2008).

\section{Interviews}

Prior to the interview, the interviewees were contacted and presented a consent form, which explained their rights, anonymity and consent for taping. The participants engaged in an audio-taped, semi-structured, open-ended format interview. Notes were taken during every interview in case of a dysfunctional taping. The tapes were sent away for transcription purposes. Once transcribed, the information was analyzed using an open-coding system that evolved during the interviews. The interviews were analyzed separately to review similarities and differences. As categories begin to emerge from the open codes, a code book was created that defined the categories. To ensure consistency, I revisited each interview to ensure the themes were understood correctly. After this, a cross comparison of interviews was completed to define interactions among themes.

In a broad view, Appendix A shows the interview question and the response from the policy, the state administrators, the county administrators, the local administrators, and the early childhood teachers. Open coding was utilized. This is displayed as in a matrix in Appendix B. Each row represents one of the thirteen interviews conducted and each column represents a question within the interview. After reviewing the matrix, categories were identified according to the interviewee's responses. This is displayed in Appendix C. The following broad categories 
emerged upon review: infrastructure, teacher certification, developmental appropriateness, curriculum, collaboration, distribution, health and safety, implementation, parents, principals, and transportation.

\section{Participants}

The participants in the study were selected based on geographical location and their relation to public school preschool, specifically Policy 2525. A series of 13 interviews were conducted and included three state administrators, three county administrators, three local school administrators, and three early childhood certified teachers. An additional interview was conducted with a state government official to provide perspective on the birth of the policy.

\section{Reliability and Validity}

Various strategies were utilized throughout the study to ensure reliability and validity. While this study may be replicated, due to its qualitative nature the reliability will be measured within the present study. The use of triangulation confirms the analysis of interview data by strengthening the study (Patton, 2002, p. 247). In this study, I utilized interviews, relevant literature, a review of Policy 2525, and federal and state policies outlining similar objectives as held in Policy 2525. The discourse model is evident between the "micro" and "macro" level of the institutions and the mediation between the two (Gee, 2005, p. 71). This relationship is displayed in figure 4, which will provide cross-data validity checks (Patton, 2002, p. 248). 
Figure 4

Triangulation

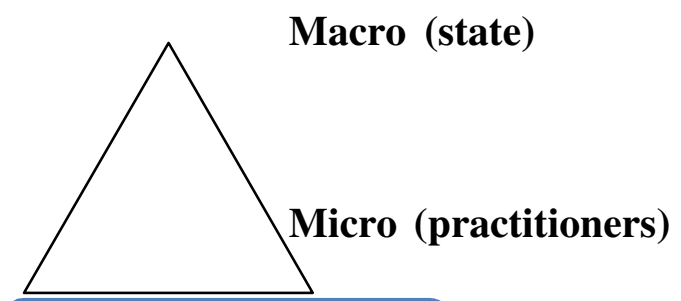

Interviews of invoved personnel

from Macro (state) level to Micro

(practitioners) leading to

discrepencies between espoused

theories from Policy 2525 to practice

in local communities

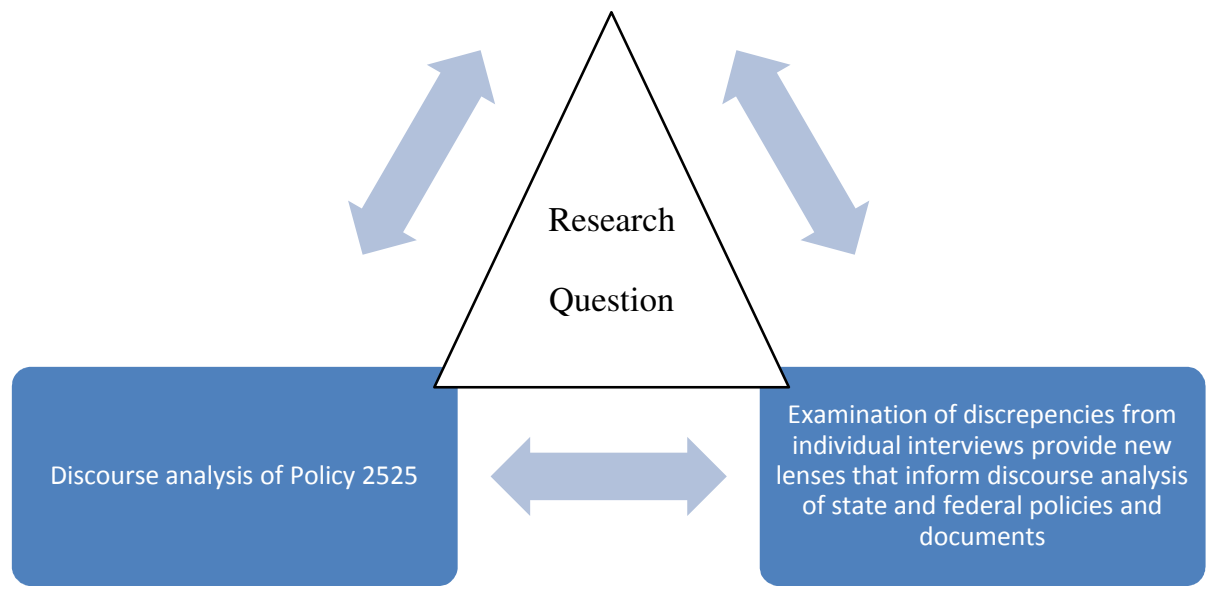


The question of replicating the results is not critical (Glesne \& Peshkin, 1992), but precision (Winter, 2000), credibility, and transferability (Hoepfl, 1997, p. 58) provide the lenses for evaluating the findings of a qualitative research (Golafshani, 2003, p. 600). The credibility of this qualitative research study depends on the ability and effort of myself (Golafshani, 2003, p. 600) as the researcher.

\section{Researcher}

\section{Assumptions and Limitations}

Qualitative researchers seek illumination, understanding, and extrapolation to similar situations (Golafshani, 2003; Hoepfl, 1997). In Discourse Analysis, I understand that I entered the study with preconceived biases and an emotional connection. As noted in Chapter 1, my previous position as an early childhood educator influences my opinions and beliefs about the manner in which Policy 2525 was initially implemented the structure of a preschool classroom, and the necessity for early childhood education.

As a parent, I have a preconceived design of what an early childhood classroom and teacher should resemble. This perspective was noted and every effort was made to review others perspectives and recognize their views. Therefore, I was able to comprehend Policy 2525 and the implementation.

\section{Chapter Summary}

This chapter provided an overview of the discourse analysis study in regards to Policy 2525, while also describing the data collection process and the way in which the data was analyzed. The discrepancy model is embedded within the discourse analysis. It highlights the discrepancies between Policy 2525 and the practice occurring in the classroom within a small 
segment of early childhood in West Virginia. The fourth chapter will describe the results that have been collected from the design outlined above. 


\section{CHAPTER 4: RESULTS}

\section{Introduction}

In this chapter, the results from the interviews are presented. The interviewees are introduced within their role groups, the major themes are identified and analyzed, the connection between the research questions and the role groups is acknowledged, and the questions will be compared across role groups, if appropriate. Finally, a holistic analysis will be provided. The following research questions are addressed:

1. How do participants' define their roles in the implementation of universal preschool education in West Virginia?

2. What are participants' understandings of the goals of universal preschool education in West Virginia?

3. What are participants' perspectives of the benefits and challenges of universal preschool education in West Virginia?

4. How is universal preschool being implemented in West Virginia?

5. How does the enacted policy compare to the legislated intent of the policy?

\section{Methods}

As a source of reference, I conducted a document analysis of Policy 2525 West Virginia's Universal Access to a Quality Early Education System. The policy was used as a reference for educational jargon which the interviewees utilize. It was also a cross reference to specific notations directly from the policy. Entering the interviews, I viewed the policy not only as the framework for this investigation but also as the framework that guided the action within the classroom and administratively. 
I conducted semi-structured, open-ended interviews with various types of individuals: a former state government official, early childhood state administrators, early childhood county administrators, principals that house early childhood classrooms with their schools, and early childhood teachers. I asked the interviewees the same twelve questions. In order to maintain anonymity, the interviewees' names are fictional.

It should be noted that the policy is scheduled for complete revision in 2009-2010. This is the first time that it has not been revised every two years, as the counties requested a delay. Currently, only clarification about case loads and funding are added as necessary.

\section{Interviewees}

Thirteen interviews were conducted in this study. In order to have a clearer picture of the interviewees, it is imperative to understand their positions, backgrounds, and their Regional Service Educational Agency (RESA) within the state.

Dave, a state government representative, has an educational background in law. He served in multiple educational committees and resides in RESA III.

The second group included state early childhood administrators and all work in RESA III. Jackson, Hilton and Reagan are all housed in the West Virginia Department of Education. Jackson's background is in curriculum and guidance. Hilton's expertise is in behaviorism, genetic counseling, intervention, and community agency. Reagan has a curriculum and instruction, early childhood teaching background.

The third group included county early childhood administrators. Heather, Leslie, and Jeff held degrees or certifications in administration, special education, elementary education and early childhood, respectively. All three interviewees work in RESA VII. This group primarily 
was responsible for following the regulations of the policy. Heather and Leslie both spent time in the classroom prior to their current positions.

Local school administrators, Beth, Holly, and Stephanie comprised the fourth group of interviewees. Beth and Holly are employed in RESA IV and Stephanie in RESA VI. They also held degrees in curriculum and instruction, elementary education, early childhood, administration, and elementary education, respectively. All three of the interviewees were classroom teachers at some point prior to their current position. Holly is currently retired from the school system but maintains an active role in administering the Early Childhood Environment Rating Scale-Revised (ECERS-R) and sits on an early childhood advisory council. While with the school system, she was present during the initial implementation of Policy 2525 and remained with them until three years ago.

Finally, the fifth group of interviewees consisted of practicing early childhood teachers. RESA VII is where Lindsay, Marie, and Bethany work. Both Lindsay and Marie have a master's degree in curriculum and instruction, specifically early childhood; Marie's undergraduate degree is in special education. The third teacher, Bethany, has an undergraduate degree in elementary education with a certification in early childhood. 
The following table, Table 3, provides a brief glimpse of the educational level and role each interviewee plays within early childhood education.

Table 3

Name, Education, and Roles of Interviewees

\begin{tabular}{|c|c|c|c|}
\hline Name & Education & $*$ Role & **Location within state \\
\hline Jackson & Curriculum \& guidance & State EC administrator & RESA III \\
\hline Hilton & $\begin{array}{l}\text { Behaviorism, genetic } \\
\text { counseling, intervention, and } \\
\text { community agency counseling }\end{array}$ & State EC administrator & RESA II \\
\hline Reagan & Elementary education & State EC administrator & RESA III \\
\hline Heather & $\begin{array}{l}\text { Administration, elementary } \\
\text { education }\end{array}$ & County EC administrator & RESA VII \\
\hline Leslie & Special education & County EC administrator & RESA VII \\
\hline Jeff & $\begin{array}{l}\text { Administration, curriculum \& } \\
\text { instruction }\end{array}$ & County EC administrator & RESA VII \\
\hline Beth & $\begin{array}{l}\text { Elementary education, } \\
\text { administration }\end{array}$ & Local administrator & RESA IV \\
\hline Holly & $\begin{array}{l}\text { Elementary education, } \\
\text { administration }\end{array}$ & Local EC administrator & RESA IV \\
\hline Stephanie & Curriculum \& instruction & Local EC administrator & RESA VI \\
\hline
\end{tabular}




$\begin{array}{llll}\text { Lindsay } & \text { Curriculum \& instruction, EC } & \text { EC teacher } & \text { RESA VII } \\ \text { Marie } & \begin{array}{l}\text { Special education, curriculum } \\ \text { \& instruction, EC }\end{array} & \text { EC teacher } & \text { RESA VII } \\ \text { Bethany } & \text { Elementary education, EC } & \text { EC teacher } & \text { RESA VII } \\ \text { Dave } & \text { Law } & \text { State government representative } & \text { RESA III }\end{array}$

*Interviewees grouped by Role

**See Appendix D for RESA's within West Virginia 
Findings

\section{Broad Findings}

An analysis of the answers obtained from the interview groups revealed several broad themes that need more in-depth scrutiny. They include: 1) relationships within collaborative environments; 2) the benefit of quality early childhood settings and experiences; and 3) the infrastructure of the policy. These three issues are the essence of this policy and may determine its success or failure.

\section{Relationships within collaborative environment.}

The interviewees cite a commonality in the worth of collaboration, specifically with childcare partners, public school systems, and the Department of Human Resources (DHHR). "Collaboration is key" stated Hilton. When organizations work together, the children benefit. Hilton continued,

(Preschool) prepares children to be lifelong learners. Three and four year old is such an important year not that any other year isn't. The curriculum and assessment in policy is that making sure using play based curriculum, not using worksheets, not doing certain content in isolation but that they do have content and quality instruction not just free-for-all out there in classrooms. Sometimes there is a misconception that there is not direct instruction in teaching but there should be.... (The biggest benefit is) is the service to children. 
Heather further explained from a county perspective,

I think it is good to partner with other groups in the county so that families that need child care or choose to go to a more private pre-k be consistent whatever that we partner with them and insure there is continuity in the county schools. We know that all these children are coming into our kindergarten programs in most respects so we want them to have the same experiences as much as possible, not cookie cutter but to a certain extent control and have children with the same experiences. That way working families can have their children in child care centers and feel they are getting the same thing that they would get if they were in school.

The children are the reason separate entities, as such as public and private pre-k programs, must work together. These organizations must work together in a productive and effective manner in order to reach the common goal of developmentally appropriate preschool education for all children.

While policy requires a 50/50 collaboration with child care centers, this number is often debated because of county dynamics. There are some counties that have only one child care center or they have a center that is not of quality. Heather clarified her wish, 
I think parent's wishes drive the number of classrooms and not some arbitrary number. I imagine that came out because they knew school systems would be reticent to the child care centers...I still think an arbitrary number is wrong and it should be by community needs and I think each county can prove their community needs by seeing where the parents sign-up. If they have a huge wait list of child care centers, then more partnerships are needed.

The issue of quality collaborative surfaced in the interviews. How are the child care centers selected? Jeff mentioned that he wonders why some child care centers chose to align with the school system and others do not. Leslie also raised the issue of quality.

If we are going to collaborate with a center and put a school system name with it, then we have got to come up with a way that is a quality center. I have not seen anywhere in the guidelines of the policy saying you have to come up with a certain ECERS score to be able to collaborate. It is very difficult to say based on your reputation; you are really not a quality child care center. We are not going to collaborate with you. There are some (child care centers) that are not quality and I do not want my name associated with that. I am happy to invite them to trainings and help them 
become a quality center but until that happens; I do not want my name associated with that.

Both Jeff and Leslie's positions are greatly influenced by the quality of the centers they surround themselves by. It is important to surround yourself with good people or in this case, good centers. They directly reflect achievements. Just as we regulate people that we associate with, schools systems need to somehow regulate centers they collaborate with.

Hilton stated, "Those sites that we collaborate with are quality programs and vice versa." There is a sense of obligation and responsibility to your collaborative partners. Quality is imperative. "Counties that have really strong, lasting relationships with their collaborative partners have excellent programs," Hilton reiterated.

The benefit of quality early childhood settings and experiences

"The children are benefitting because it is quality," said Holly. Families and community members are beginning to understand what preschool entails. Leslie, at the county level, feels that this is

proven by CreativeCurriculum.net and having to be accountable for children's progress. That seems to be making a difference instead of just saying this is free play. People are starting to understand that there are goals and objectives that the children are expected to meet and the teachers are expected to teach. 
CreativeCurriculum.net is an online assessment tool. It is designed specifically for early childhood programs to manage ongoing assessment. It is a simplified way to share assessment material with families.

Social experiences are an important piece in the preschool classroom, since establishing peer relationships is critical throughout life. Early childhood peer relationships are ones they will carry with them throughout their lives. Marie, an early childhood teacher in RESA VII, addressed these social issues, "I really think that having social interactions prepares the child for kindergarten. Whether they get anything academically or not, just having that whole learning, the routine of the day and the interaction with peers is beneficial. Negotiation skills really benefit the children." At the end of the day, Hilton's main concern is "helping (preschoolers) learn how to build relationships, trust, and be sociable." This is an overarching goal that everyone associated with the policy should try strive for. Due to Hilton being in a state administration position, he reviews items more broadly rather than narrowly.

The policy provides a framework for individuals to use as reinforcement for debate. Stephanie, a local administrator, describes how she refers to the policy, "When you know there is an issue in a classroom you can cite the policy chapter and verse and it is your crutch for trying to assist in implementation of best practice...I just knew what was best practice but I did not have a hammer, so this is more my hammer."

The infrastructure of the policy

There are discrepancies in early childhood and possible solutions have been identified; yet, the challenge remains significant (S. L. Kagan \& Cohen, 1996, p. 125). Infrastructure is a challenge that was noted in multiple interviews. For the purposes of this study, infrastructure 
issues include teacher certification, the early childhood building, bus transportation, and early childhood curriculum.

Teacher certification. Leaving the profession with historically inadequate pay, early childhood positions have been gender biased, assuming that only women were qualified to teach early childhood. The foundation for early childhood positions has been maternal and instinctive based rather than teacher education or preparation based. The low salary has left many educators searching for other employment opportunities with higher pay and more stability. The result is a high turnover rate (Gammage, 2006, p. 241; Horm-Wingerd et al., 2000; Neugebauer, 2008, p. 26) and inexperienced teachers teaching young children.

State administrator housed in RESA III, Jackson stated,

Certification of teachers, nobody wants to talk about it. We have permanent authorization which has been great to allow us to grow the program so rapidly that we have allowed people with two year degrees and our community partnerships. But again go back to the research that the more education you have, the higher quality. I was actually with Steve Barnett at a workshop in the fall from NIERR and he had to clarify his own research for folks there. They said, 'you know, your research says you get more impact with a four-year degree than a two and as the stages go up.' He said, 'that is not exactly true, education does matter but if you read the research very clear but are the classes, within that education, targeted to preschool.' A four-year teaching degree does not 
necessarily equate to a higher quality level than a two year teaching head start teacher. Is the four-year degree or the master degree specifically in early childhood?

The National Association for the Education of Young Children (NAEYC), National Council for Accreditation of Teacher Education (NCATE), and National Research Council (NRC) recommend that teachers hold a four-year college degree and specialized training in early childhood. Early et al (2007, p. 577) writes, "Teachers do not work in a vacuum but instead are part of a larger educational system" thus influencing teaching strategies and student results.

To get from teacher education to the impact on pupils' learning requires a chain of evidence with several critical links: empirical evidence demonstrating the link between teacher preparation programs and teacher candidates' learning, empirical evidence demonstrating the link between teacher candidates' learning and their practices in actual classrooms, and empirical evidence demonstrating the link between graduates' practices and what and how much their pupils learn. Individually, each of these links is complex and challenging to estimate. When they are combined, the challenges are multiplied. There are often substantial time lags between the teacher preparation period and the eventual measures of pupils' achievement or other outcomes; there are many confounding and intervening variables (which themselves are difficult to measure) that influence what teachers are able to do and what their pupils learn; and the sites where candidates complete fieldwork and eventually teach are quite different from one another in context, school culture, resources, students, and communities (Cochran-Smith, 2005, p. 303 as found in Bogard et al, 2008, p. 3). 
School Buildings. Elementary schools were built at a time when the youngest children in the school were kindergarten students; presently, this is not the case. From the perspective of a teacher, the policy is very different when looking at the physical building. Bethany, an early childhood teacher in RESA VII, told the following story,

They (kindergarten) have bathrooms and we would love to have one potty...We ate in our classroom. I have had accidents where I have had a child sitting on a very high stool telling a story, turned around, got excited and slipped off and hit his head and got staples. We are in this great big cafeteria with 60 other pre-k kids. The noise level is off the charts. They are not even screaming or yelling; they are just talking all at the same time. And your goals are, for your special needs kids, you have a lot of language goals. I will be sitting saying 'yeah, good job' to a kid and they might be telling me their mom robbed a bank. I do not know what they are saying. I cannot hear. We have had on occasion the opportunity to eat in our room. It was beautiful. The kids had conversations. We learned more in those one or two days about the children than we have all year.

Heather spoke briefly about the relationship between principals and the building, specifically the playground. "When we say to them, 'your playground is really not right' and they say 'we spent all this money on equipment. Yes, it is for 5-year-olds but it is not for 3 or 4- 
year olds. So we are starting to get more playground equipment and even separate playgrounds for our children."

The preschool classroom, playground, and cafeteria must meet the children's developmentally appropriate needs. This becomes an issue because schools were not built to house preschool children; however, they have been placed inside the facility. Children that range from 3 to 5-years old require certain structures. They require smaller bathroom facilities as well as developmentally appropriate playground equipment which also minimize accidents. They require a more intimate eating facility, such as the classroom. Teacher assistance is often needed to open milks, prepare food, and engage in appropriate dinner table dialogue. It is not unusual for preparation of such appropriate settings to become a funding issue. This is a legitimate concern as the cost to create these facilities is substantial.

Transportation. Transportation is a relevant topic that surfaced through several interviews. Currently, preschool children, in a public school setting, ride the school bus with grades K-5. Unless they are special needs and their individualized education plans deems it necessary, they ride without seatbelts, car seats or safety restraints. This becomes a safety issue because the West Virginia Department of Transportation states that children 1 to 4 - years - old, from 20 to 40 pounds, must be in a convertible seat, forward facing, or a high back booster or harness. Children 4 to at least 8 years of age, unless 4'9,' must be in a belt-positioning booster or high back belt positioning booster. Unfortunately, in $§ 17 \mathrm{C}-15-46$, Child passenger safety devices are required; child safety seats and booster seats. Note the exclusion that this does not apply to a vehicle operated for hire, meaning a school bus. Bethany, a classroom teacher, explained, "Legally, with a car you are supposed to put children in a car seat. I have a child that 
is 29 pounds. I have some babies. A regular school bus, that is frightening." Bethany takes the children off the bus everyday and views this safety concern regularly.

Also, it should be noted that transportation is not a requirement in Policy 2525; it is considered a support, not a mandated service. That being said, "you go to any rural county, they will tell you, if we do not provide transportation, the children will not come," stated Jackson, a state administrator. As a state administrator, Jackson understands the broad issues that concern the policy. Also, complaints have been received regarding transportation.

Curriculum. Curriculum is essential in the preschool classroom. It needs to be emergent and student led. Policy 2525 is very specific regarding curriculum implementation. The section 2.1 and §126-28-10 Curriculum and Assessment guides curriculum instruction. Beth, a local school administrator, reiterates that "Creative Curriculum and West Virginia Early Learning Standards Framework (WVELSF) should guide the instruction and planning." Jackson says, the policy "details you cannot do this in the classroom. You cannot use worksheets. You cannot offer content in isolation because 4 - year - olds do not learn that way." This is powerful that the policy outlines curriculum and important that people recognize that this is based on research.

Leslie provides a very important real-life perspective,

What we really need to be doing is helping kids figure out the answers to their own questions so if a child asks you something like, 'Is this a tree frog?' Instead of answering the question with a yes or no, we need to question. 'What makes you think this is a tree frog? How can we find out if that is a tree frog?' Try to lead 
them and guide them to finding out the answers to their questions...we are teaching children to think and solve problems.

Problem solving is critical for the developmentally appropriate classroom, as 4 - year olds do not learn in isolation, they learn through inquiry. The research emphasizing what developmentally-appropriate learning for this age group was conducted before the policy was written.

I think that by using creative curriculum that helps to support the policy. However, one downfall of that is I also think that people do not really know the preschool standards. They just think that Creative Curriculum is the standards and it is not the standards. Now, if you follow creative curriculum, then you are probably implementing the standards but I think if you ask some of the preschool teachers what are your content standards, I do not think any of them have really seen that in certain areas we are supposed to be covering.

This above statement from Marie alerts the reader to the fact that even though the policy dictates an approved curricular framework, Creative Curriculum, it is not the standard that guides the learning in the classroom. This needs to be addressed more thoroughly with teachers. 


\section{Educational Jargon}

One of the biggest discrepancies was the language utilized by different role groups. While it was not difficult to decipher the definitions or the meaning behind the language, there was a discrepancy in the language. State administrators often spoke in broad policy terms, and educational jargon. Due to their positions, state administrators have a job requirement to be able to recite and illustrate specifics in regards to the policy. Hilton, an EC state administrator employed in RESA III, specifically quoted section $§ 126-28-16$, Program evaluation for quality improvement in terms of ECERS and his position. Jackson also knew,

Policy 2525 is pretty daunting. There are 16 sections to it. It is unlike many of the policies that you have for the typical K12...Policy 2525 is everything. Everything from health and safety to personnel to program evaluation, collaboration. Everything about West Virginia preschool Policy 2525 is so different than the $\mathrm{K}-12$. It does take a person in this position to interpret, assist, offer the TA. Not to mention the K-12 world has been under the No Child Left Behind. Policy 2525 is preschool does not follow under No Child Left Behind. It is exempt because it is under compulsory attendance.

Jackson spoke of specific policies that impact Policy 2525. "We have a preschool special needs person to handle the 2419 inclusion." In no other interview was information 
directly quoted or noted from the policy. While the interviewees were not able to quote policy numbers or verse, they maintained consistent understanding of the goals of preschool education.

Lindsay, an early childhood teacher in RESA VII, told me that she had not seen the policy in quite some time, possibly years. "I really do try everything in my bachelor's and my master's and in the professional development courses. I have implemented in my class everything my administrators tell me to do, I do. I am sure that is through the policy." Lindsay was dependent upon her educational knowledge and the knowledge of her administrators to guide what was appropriate in terms of the policy. She trusted that her administrator knew the policy well enough to properly implement it. Lindsay also knew that the policy was research based and aligned developmentally and that she could trust that it matched up with her education. Even though Marie and Bethany, in their previous positions, had more direct contact with the policy, they spoke in general terms. The early childhood teachers often spoke about their students and their classrooms. Their discussion items were more situational based. This difference is to be expected. Educational position influences the language used. The further removed from the students, the more educational jargon is utilized. The closer the contact with the students, the more lay terms are employed. Make no exception, early childhood teachers still need to have read the policy and have an understanding of it.

\section{Within role group/Across role groups}

State government representative. Working from a hierarchical point of view, we will begin with the state government representative, Dave. This will provide a framework and foundation for the evolution of Policy 2525. Prior to addressing the research questions, I will provide a historical context of the development of Policy 2525. At the same time, it will describe Dave's role in the implementation of the policy. Dave's role in government consisted of being elected to the 
Legislature, chairing the Senate Education Committee and chairing the Finance Subcommittee of Education. The latter leaned towards the policy side. There were three events that Dave felt encouraged the development of the policy. The first was the literature reviews that Legislators read. Second, the Education Commission of the state focused on the early brain development research. Finally, his membership on the Southern Education Board, which focused on early childhood. "Put all those sources together and it became increasingly clear that we weren't going to catch up in West Virginia to where we needed to be if our kids started so far behind...It became increasingly clear, at least to me, we had to get our kids starting at a higher level.," Dave, a state government representative houses in RESA III, stated.

Initially, a comprehensive program, Educare, was developed that served birth to 5; the cost was roughly 85 million dollars. At the same time, a mandatory kindergarten requirement imposed on counties almost bankrupted counties because of a lack of money provided to implement kindergarten. As counties began the implementation, they were including children with little money. Thus, they had to compensate for the lack of funds. Dave noted,

What we were starting to see in counties is that they got smart. If they were starting to lose enrollment, which most counties in the state at the time were, and add students at the same time we were losing enrollment, we will have enough money to fund those students and the next year we won't lose that money which we would have otherwise lost 
because the budget is always a year behind in West Virginia education. This state aid formula is critical in the development of Policy 2525.

Because Ashe County was losing a large number of students due to graduation and moving, they began adding 4 - year - olds to continue their state reimbursement. At that point, they found themselves in direct competition with Head Start. The problem arose when federal money from Head Start began replacing state money. Counties continued placing 4 - year - olds in the schools. They did not want to discontinue the program so the Legislature decided that what was needed is a "comprehensive 4 - year - old program. One that makes everybody play together," Dave said. It was critical that Head Start held rights. Dave "drafted a bill that I thought would solve various issues but at the same time carving out a small piece of Educare. We could not fund the whole Educare program so we carved out a piece of it to fund through the state aid fund formula... Once those kids find their way into state aid formula, it is an entitlement. It has to be funded. The formula drives its own dollars."

Dave focused the policy on five elements: health and safety, curriculum, student teacher ratio, class size, and teacher qualifications. "The real benefit of the policy is that it addresses the policy issues that are important for this thing to work, work correctly, and have quality. Quality was the issue, quality," Dave professed.

Preschool is "important to our education system as a whole, that kids get a head start and keep up because once they get behind their brains get developed in ways that are more difficult to deal with that you may never catch these kids up," said Dave. While this may be a benefit of the program, it is also a challenge to explain to the community.

Quality was reiterated throughout the interview with Dave. He stated his concern very clearly, that "programs that are implemented in numbers but not in quality. You can't do this 
with people that aren't qualified to teach. We know you can't do it if classes are too large, the wrong ratios. Quality matters almost more at that age than any age." This belief in quality was driven by Dave's family experience. He shared the following story,

My wife drove my children beginning at age 3, because there wasn't any early childhood experiences here. My wife drove our kids, everyday, one hour each way for 4 years. (It) started out 2 days a week, 3 days, 4 days depending upon their age. We knew our boys needed to have that experience. We drove them down just so they could have that experience. It was good for them...It was something we had to do. This is what I knew every kid in the county and every kid in the state deserved the same opportunity because I saw what it did for my boys. We tried to make that happen for every child in the state.

State administrators. The state administration group consisted of Jackson, Hilton and Reagan. Overseeing the entire early childhood department and the administrative side is Jackson. Hilton and Reagan are responsible for specific pieces within the policy. Hilton is responsible for the implementation of ECERS and the evaluation piece. Reagan handles the training on curriculum and assessment. Reagan described her positions as "want(ing) to make sure that they're (teachers) doing a play based curriculum, not using worksheets, they're not doing certain content in isolation but that they do have content. They have quality instruction not just free-for-all out there in the classrooms." 
Throughout this group of interviews and the other ten interviews, the same goal was reiterated. "The overarching goal of Policy 2525 is a very broad set of goals, a space for every single 4-year-old, a 3-year-old with an IEP, who wants to be a part of pre-k, public supported pre-k," summarizes Jackson. Specifically, Bethany, an early childhood educator stated, the goal to be "providing developmentally appropriate education and care for children 3-5 with all disabilities, typically developing, socioeconomic." The key words are 'every child' and 'developmentally appropriate.' If the program is implemented but not geared towards early childhood needs, then it is not meeting the quality standard expressed in the policy.

Implementation holds many different benefits and challenges to preschool. Hilton clarified the importance of implementation.

When the policy is implemented with some rigor, then we are assuring our programs are relevant to the population that we are trying to teach. That we give children concrete experiences, hands on, whole body experiences so when that wonderful time down the road they start getting hit with a lot of abstractions in education, they will have a solid, concrete point of reference.

The policy also provides "a clear message to the average citizen of what it means to have quality early childhood experiences...It does not matter whether you attend West Virginia pre-k or not, there are quality experiences for every child," states Jackson. 
On the flip side, there are challenges regarding the implementation of the policy. Equity of services is difficult when it is being carried out in 55 counties and 900 classrooms, with 14,000 students throughout West Virginia.

The second theme that was continuously revisited on every interview was collaboration. "Sometimes different partners have different views and different outlooks...I do think sometimes the biggest challenge is the relationship between the people that are in those fields," said Reagan, an early childhood state administrator employed in RESA III. When relationships are negative, the children suffer. Often collaboration problems are rooted in funding issues instead of educational issues. While collaboration can cause great turmoil, it also can create successful programs. "In counties that have really strong, lasting relationships with their collaborative partners, (they) have excellent programs," Hilton agreed. He also noted that collaborative partners need to be "quality programs" and uphold a level of responsibility to the partners.

Teacher certification is the final issue that surfaced for areas of improvement. Section 2.1.7, in Policy 2525, states the importance of employing staff with strong professional education preparation in child development and early childhood education.

I don't think a teacher's certificate makes you a good teacher. I went to public school. Every teacher I had, had a certificate. Every teacher I had wasn't a good teacher. With that being said, I don't know how you change it, declared Hilton.

His possible solution involved engaging certified pre-k teachers in "ongoing evaluations to ensure that those skills and those theories are applied and, if they are not, then there would be 
some sort of continual professional development training that will help achieve that excellence." Permanent authorization is an option which allows teachers to rapidly enlarge the program. Jackson clarified the position on research stating that the more education, the better quality of teacher, but the important piece that is often overlooked is "the classes, within that education, targeted to preschool." The state has "acknowledged six specific classes that, if you are going to be exempt from holding a 4 - year degree, you will agree these are the six classes you will take." Jackson believes the strongest part of the policy is the classroom implementation. However, Reagan feels the focus should be the preparation of children to be lifelong learners. Hilton says, "We were looking at the health and safety and relational and social issues and, if we could get through all those, we could do well."

The longitudinal research on the impact of preschool is limited. The Perry High Scope study is the one to which everyone refers, but realistically "nobody has that kind of money and that kind of resources to dedicate" (Jackson, 2009). Just as Reagan stated earlier, lifelong learners, confident children, and a disposition to learning are the hopes of children attending preschool. In order for the policy to be successful, Hilton notes, "As long as the document stays alive, so we can go in and do revisions and we do that for the best of the children, then the policy will be a benefitted factor." This will impact the legislated intent of the policy and the enacted policy.

County administrators. Heather, Leslie, and Jeff were the three county administrators interviewed. Heather is manager of pre-k and Head Start; Leslie is the curriculum coordinator for pre-k and kindergarten; Jeff holds a more global county position. Administrative certifications are required for each of their positions. According to Heather and Leslie, both county EC administrators houses in RESA VII, the "responsibility is to the school system to 
make sure we are following the 2525 regulations as we implement that policy." Jeff's position requires him to make the policy for the county.

The goal of Policy 2525 is clearly stated by Leslie, to "provide a seamless quality early care for all children." It is important for all these children to have continuity in experiences because "we know that all these children are coming into our kindergarten programs in most respects so we want them to have the same experiences as much as possible, not cookie cutter, but to a certain extent have children with the same experiences," defined Heather. This is grounded in partnerships with child care entities. Families that attend child care settings, such as day care, do so because they need more long term care. With the policy in place, this allows those collaborations to maintain the same quality of care.

The recognition of what is developmentally appropriate for 3 and 4 - year - olds is essential to the success of this policy. Principals are recognizing that preschoolers do not fit into the traditional school rules; "like, I can allow pre-k to have to go down the hall in twosies...it is ok to have them side-by-side going down the hall. Walking, that is even amazing," reflected Heather. "Children are teaching adults the rules. At least we are listening," declared Heather. This education does not stop with principals but extends to collaborative partners. "Training is being provided to collaborative partners to ensure that children are getting a comparable pre-k experience," summarized Leslie. "It also educates the children. The children are acclimating to the school system at an earlier age," Jeff explained, a county EC administrator employed in RESA VII. As with any policy, challenges accompany benefits. The challenges range from teacher certification issues, to Head Start income guidelines, to teacher support in the classrooms. Jeff noted, 
Yes, we have people who work directly with the policy. It is their responsibility to incorporate the policy... This year I made a point of going out to visit all the child care centers. Where they are, what they are working on. Those are still our children. We have a direct responsibility to those children.

The members with direct responsibility to the policy are involved in the following: engaging in writing the pre-k plan; overseeing all the classrooms, teachers and collaborative partners; writing contracts and negotiations; and serving as the contact person for all pre-k sites.

Policy 2525 was legislated for the benefit of children. The enacted policy is the living classroom. Heather explained,

We both know how much children learn when they are young and by waiting until you turn five to start your learning, it could be too late, in a way. You need to start those enriched environments and rich conversations much earlier with children. (It is) a time to play and learn to play which is exactly what they should be doing. Learning how to work and play with their peers will get their self esteem or help establish their self esteem,

Jeff concurred, "pre-k is a developmental program allowing for social issues, play issues."

Local school administrators. Beth, Holly, and Stephanie are the group of local school administrators. As in the county school administrator group, all three hold administrative 
certification. Beth's position required her to remain current on policies and procedures so that she could ensure teachers were following policy. Holly is recently retired but her position required her to write Head Start grants, follow policy, and write contracts with collaborative partners. Stephanie's position involves training and monitoring the preschool teachers.

Stephanie, a local administrator employed in RESA VI, reiterated what all interviewees said about the goal, which is "that every 4 - year - old in the state of West Virginia will have access to free and appropriate preschool." Beth, a local administrator in RESA IV, summarized the policy by saying, "This policy ensures that preschools around the state follow the same guidelines for health, safety, teacher certification, inclusion, curriculum, materials, environment, and ongoing monitoring."

Beth touched on the importance of free preschool: "Before, children attended preschool only if the parents had the income to support their attendance in private school. Children with special needs were separated from their same age peers... It is wonderful to see equality in education." While the money issue is reduced at the family level, it is a challenge at the local and state level. "As with many initiatives, there is not enough state or local money to support Policy 2525... Money needs to support the creation of these classrooms, the hiring of the staff, and the training for school and/or collaborative support staff," stated Beth. Holly, a local EC administrator in RESA IV, revealed the difficulties with collaboration and funding: "You have three separately funded agencies, separately administered agencies." They are driven by different dollars and different beliefs.

It is interesting to note Stephanie feelings regarding implementation. She said, 
It varies from county to county. Each county is at a different level. Some counties are deemed universal and some counties really aren't there yet. When I say they are not there, I mean not every 4 - year - old is getting the same service that someone in the next community maybe might be getting. The levels of implementation are very different from county to county.

These statements explain why the policy was enacted: to maintain consistency across sites, counties, and throughout the state. As humans, we all interpret words based on our previous experiences. In this case, sites may be basing the policy upon their community's needs, their funding, and their access to qualified teachers. This concept also reappeared in the interview with Bethany, an early childhood teacher. She summarized her feelings from working in one county to another as "I have gone from a one room school house to a penitentiary. That is what I feel like...I am coming from somewhere that all they do is pre-k. You are not somewhere were all they do it pre-k. It is not all about pre-k."

Holly emphasized that the immediate benefit to early childhood education is that the policy is research based. She acknowledged,

Policy 2525 is research based in that they have identified what is a good environment for a 4 - year - old. How does the child learn best? They learn best if there are opportunities for exploration and they get to make choices and they get to experiment. So we know those things are true because it is research based. 2525 pulled this 
all together...It is good because it is mandated. Who is going to

benefit? The children are benefiting because it is quality.

Stephanie acknowledged it sets a standard: "If you want to be deemed universal, if you want to be recognized, you have to show that you are following it (policy). So it does set a standard."

As noted in previous interviews, the long term implications of early childhood education include creating life-long learners. "They are like little sponges so they are really getting a kick start to benefit their entire education career at whatever level they go to. And it is a very important year and it is one that can only benefit them," Holly described.

Early childhood teachers. It should be noted that two of the three teacher identified had previous knowledge of Policy 2525. Both Marie and Bethany held previous positions that allowed them to deal specifically with issues surrounding Policy 2525. This is Bethany's first year with the board of education. One of her previous positions was the head teacher for a pilot preschool program. It was my perception that Bethany was disgruntled regarding her position in the public school system. While I believe she had the best interest of the children in mind and made very valid points, her ideas will be weakened by the negativity that she projects. Marie's previous position required her to be on the county committee for implementation of Policy 2525 and a member of the advisory council at the state level. I believe their prior positions gave them a different breadth of information and background than a teacher who has not held similar roles, which may have skewed the information that I received during these interviews. The final participant in this group, Lindsay, is a head teacher and assistant director at a child care collaborative setting. She has ten children in her classroom and has no aide. 
This group was no different than the previous groups in their belief of a quality education for all. Marie summarizes this: "The overall goal is that it would enable any 4 - year - old living in the state of West Virginia an opportunity for a preschool education.”

The general consensus of the early childhood teacher group was that the major benefits of the policy are the early exposure to school, the social experience the children receive, and the opportunity for all children to be provided with the chance to attend preschool. Bethany concurred with the latter statement: "I think it is wonderful that is does give free pre-k to families that need it and families that do not. For a lot of time, we have been taking care of the families that do not have the money. There are those families that are kind of there in the middle that just are not making it and we can take care of them." This equity of services is crucial for the success of the policy. As counties become universal, the labels of Head Start, special needs, pre$\mathrm{k}$ will start to slowly disappear. It will become more integrated and less defined with regard to where the funding originates.

Typically, with any new policy there are always challenges to overcome; Policy 2525 is no different. The education of policymakers, administrators, and the general public is a critical topic with early childhood educators. While policymakers often demonstrate willingness to research and learn about a variety of subjects, the people involved in the implementation of the policy are often forgotten. "The people that are making the policy do not really...I mean some of them know about early childhood and things like that because I think they have to, but it is not teachers. It is not the people who are actually doing it," proclaimed Marie. The living policy, the classroom setting, is where some of the feedback and revisions should come from. "Teachers are key agents in educational processes, but they hardly ever have any participation in reforms" wrote Pini and Gorostiaga (Pini \& Gorostiaga, 2008, p. 429). These voices need to be heard. 
Meetings are held but they are during the teacher workday making it rather impossible for them to attend. Although, as Marie mentioned if "they were held at 9:00 at night or something, I am sure that nobody would come out to them either."

The administration is engaged in a learning curve. Preschool is not emphasized in most administration certification programs, so it is a new world. Bethany mentioned, "They try the best they can to understand, they just do not. It is a different world, a completely different world...I think it is something that they just do not understand."

Parents need to be educated about the benefits of preschool education. Children "need to learn sharing and just the basic concepts that you are going to need for elementary school," declared Lindsay. While it is common language for early childhood teachers to discuss preschool, it is not for everyone. Teaching parents and community members about preschool is often as important as teaching the children because, if the parents deem it important, so will the child. Educating everyone regarding the importance of preschool is at the forefront of the success of the policy.

Being that these three interviewees were classroom teachers, their descriptions of the implementation of the policy in their school or child care center were very similar. They all had special needs children and pre-k children in their classrooms. The difference was that Lindsay had no Head Start children in her classroom. In Marie's school, two preschool classrooms collaboratively work together. While there are four preschool classrooms in Bethany's school, they do little collaborative work. Bethany also felt that preschool was not well integrated into the school environment. She pointed out, 
We go to faculty meetings. If they were geared towards us or included us, that would be fine. They say, 'This does not apply to preschool, this does not apply to preschool' but we never talk about what applies to preschool. We have to follow all these things, go to these meetings, which if they were geared towards us or included us that would be fine but they are not.

Marie concurred, "If you look on our Web site, it will say such and such elementary, K through whatever, it does not even mention pre-k. Field trips or whatever, the whole school is going here...the whole school but pre-k. And I do not think it is done intentionally by an administrator."

The seamless integration of preschool continues to be a struggle. While there are instances where preschool seems to be dismissed, there are also those times that preschool is a definite asset to the school. Marie explained that due the continuously low ECERS scores, their site was able to receive funding for a developmentally appropriate playground. The original playground had been there since the school was built and need updating. Therefore, preschool has much to offer the school setting.

\section{Holistic analysis}

As I reflect upon this study, there are several ideas that emerge. First, the teacher certification issue that continuously resurfaced in the interviews was at the forefront. The value of an education is extremely important to me. In my opinion, the policy maintaining consistency in teacher's certification is critical to high quality education. There are those who disagree, like Hilton who said, “I don't think a teacher's certificate makes you a good teacher. I went to public 
school. Every teacher I had, had a certificate. Every teacher I had wasn't a good teacher." While I would agree that a piece of paper does not make a teacher, the educational experiences that the degree represents enhances a teacher's knowledge and understanding. Furthermore, the educational theories learned during acquiring the degree are then implemented and displayed in practice. Also, during this education, time is spent in the classroom learning about best practice. In my opinion, there is a clear correlation between education level attained and teacher performance, which ultimately results in improved student performance.

Second, relationships, particularly collaboration, also arose in almost every interview. As Waite and Davis (2006, p. 405) wrote, "Working together and thinking in a critical way are important skills that contribute to learning processes and to their subsequent performance in working lives." It provides the "opportunity to establish rewarding and long lasting social and professional relationships" (Gable, Mostert, \& Tonelson, 2004, p. 4). During collaborative situations, the members construct knowledge based on prior experiences.

The interesting part is that the relationships were all different based on their positions within the policy. For example, state administrators viewed collaboration with DHHR, Head Start, and county schools as critical. The effectiveness of collaboration may be based on the needs of the organization, their engagement in the collaboration process, or how problems are solved within the collaborative group. The important piece lies not in how collaboration occurs, but the result of collaboration. Organizations have found themselves in a difficult position because the policy has mandated collaboration with no direction regarding how to proceed. Every stakeholder has different needs based on his or her involvement and experiences. The intention of collaboration, as mandated by the policy, is one of value. The collaborative 
stakeholders have positive intentions, for the benefit of the children. The disconnect lies in the "intent of collaboration and what actually happens in schools" (Gable et al., 2004, p. 8).

I understand the benefit of preschool to children at all income levels. Preschool funding is provided from several sources. The problem arises when funding is needed and it makes a difference within the classroom setting. When Head Start provides paperwork, the forms are distributed to Head Start children only, which cause a clear divide within the classroom. First, the teacher identifies which children are funded and the children notice these divides and label them.

Early childhood has gained great exposure in the state of West Virginia and nationally. While growing in popularity, it is still met with a variety of challenges and opposition. These interviews provide a glimpse of the value of understanding the policy and its benefit to children and the state. It is important to have an appreciation of what the document contains and then how it is being interpreted, beginning with the top administrators.

As mentioned previously, my roots in early childhood run deeply. I began following the early childhood journey, which has taken me through the last nine years. My journey continues through this study and, hopefully, for the rest of my life.

\section{My Thoughts}

When I began this dissertation process, I went in with the idea that I would reveal a great discrepancy between early childhood administrators, at any level, and early childhood teachers. As I proceeded through the interviews, I was shocked that this was proven wrong. While the language utilized was different, the ideas were consistent. The early childhood teachers utilized their educational knowledge while state administrators, exclusively, spoke in policy terms. Due to the policy being research based, their thoughts were congruent. As I reviewed my interview 
transcription, I carefully considered the language utilized and how it was created within the context presented. This provided a methodological approach to the data presented.

During an interview, a participant mentioned that he has a child eligible for preschool, but is not sending him. I am in a similar position, but will be paying for a half-day, private preschool program for my son. The decision involved considerable self-reflection and searching. While contemplating my choice, several considerations entered my mind. First, the preschool program that I selected for my son is the same one I attended at his age. As a 4 - year - old, I attended the school and as an undergraduate Child Development and Family Studies major, I experienced a practicum there. In recent years, I have attended professional development courses on the site with the director and head teacher. Due to such direct contact, I have observed and experienced the daily activities and have been pleased. Finally, I have a relationship with the director and the head teacher. I humbly recognize that the concept in which I believe may not be the best choice for everyone. Unfortunately, many are unable to have the experiences and relationships with a prospective school that I have had; therefore, they are at a disadvantage. In addition, there is a tuition cost associated with this preschool, which may be problematic for many.

During the last nine years and especially throughout my research, this never occurred to me. As Kleinman (1999) wrote, "I had good questions and observations back then, but no analysis." It took one sentence, a sentence about placement of a child in an educational setting, from an interview for me to recognize and analyze my own behavior and thoughts.

\section{Conclusion}

While the story did not unfold as I had initially anticipated, it is a good story because it is one of success. I believe Policy 2525 is a document that provides a good framework for a 
developmentally appropriate preschool setting. The people involved in the development and implementation of the policy believe in it.

The interviewees were realistic; they all noted flaws and imperfections within the legislated policy and the implemented policy. The important point is that they were able to engage in discussing how to make Policy 2525 successful for the children. Whether it is the state government official or the teacher who engages the children daily, everyone was striving for the same goal, which is a successful program for the children. While many counties' programs have been deemed universal, there are many other counties that can learn from their experiences. Together, county by county, this policy will provide and sustain a quality early childhood education for all of West Virginia. 


\title{
CHAPTER 5: CONCLUSION
}

\author{
Introduction
}

This final chapter reviews the four major results from chapter 4, relates them to the literature, views possible implications for West Virginia preschools, as well as policy makers, and suggests possibilities for future research. As noted in Chapter 4, the interviewees had unsolicited agreement even though this contradicted the initial perception that great discourse would be revealed between early childhood administrators and early childhood teachers.

\section{Summary of Policy 2525}

Policy 2525 West Virginia's Universal Access to a Quality Early Education System has 16 sections, including a general summary, guidelines, definitions, parent/guardian involvement and family support, attendance, collaboration and the county plan, personnel standards, health and safety requirements, standards for preparing students, curriculum and assessment, transition and continuity, inclusive environments, staff development and training, program oversight, financing, and program evaluation for quality improvement. The above sections provide a clear and concise framework for the implementation of universal preschool in West Virginia. Each section is further described and laid out in this 27 page document. The entire policy is mandated, for all 55 counties, unless otherwise noted. Counties are required to submit a yearly plan to ensure they are following implementation.

\section{Previous Literature}

In Chapter 2, I reviewed the literature on early childhood education with regard to policy and implementation in the classroom. History is critical for understanding early childhood. It is also important to analyze other countries current perspective on education. Sometimes learning 
from early childhood areas will result in a more complete preschool system. Friedrich Froebel introduced the notion of a play based environment, a notion that continues to be seen in early childhood settings. Policy 2525, 10.4, writes about a comprehensive curricula system that contains basic criteria. It further specifies that the student is to engage in exploration, creativity and construction, engage in the learning process, and employ thinking, reasoning and problemsolving skills through strategies such as open-ended questions, investigation, imaginative and dramatic play, and peer interactions.

William Torrey Harris' idea of combining theory and practice is still being utilized in higher education institutions that house education departments. Teacher training programs continue to strive for the balance between class work and the importance of practice. West Virginia's higher education institutions continue to evolve and change based on the needs of the children, the families, the state, and the policy.

Examples of Jane Addams work can be viewed in Head Start. Children's health needs are compulsory in Head Start classrooms. Addams' settlement house provided social and educational opportunities for working class people, especially woman. Head Start provides opportunities for parents to further their education, attend trainings, and participate in their children's classroom; very similar to Addams work. The collaboration with Head Start encourages parent participation and involvement in the classroom. Many West Virginians need the opportunity to participate in workshops and trainings to provide skills and financial support for their families.

Lillian Weber's work can be seen in that in many West Virginia classrooms in that, whole group activities have been replaced by individual and small group activities. This small group learning encourages cooperation in a community setting. 
There is no doubt that early childhood has been in transition. Thankfully, it continues to grow and evolve into a separate entity from the traditional role of babysitting. People now recognize the importance of the educational experience during the early years and how the foundation for the future is built during this time.

Throughout Chapter 4, I discussed numerous areas that impact early childhood education. From those areas I have selected the following, based on the interviewees, to include for further discussion: funding, collaboration, ratio, and infrastructure.

\section{Implications and Suggestions}

There are several implications based on the factors identified. While all interviewees agreed that they want West Virginia preschool children to have access to a high quality preschool setting, they had different perceptions of Policy 2525. Interviewees in similar positions within the preschool setting had similar viewpoints. However, in order for this policy to achieve complete success, everyone in the process must have a similar understanding.

First, all 3 to 5 - year - old children are entitled to a quality, developmentally appropriate education. The impact that the preschool classroom provides is essential to the whole child. Learning environments will begin to "weave together the threads that connect not only math, sciences, the arts, and humanities, but also mind, heart, body and spirit--connections that tend to be fragmented in our current approach (standards based) (The Association for the Supervision and Curriculum Development, 2007, p. 2). Young children learn better through experience than through direct instruction. At the age of four, it is an unrealistic expectation for children to sit and listen to a lecture for an hour. As stated by state administrator Hilton; "We do not want 3 and 4 - year - olds being drilled and killed in a chair with expectations to learn things that are beyond their cognitive ability." 
A developmentally appropriate approach might involve children experiencing apples at the science center, reading stories about apples, or engaged in selling apples in dramatic play while the teacher is circulating conversing with the children at their centers. This type of teaching is in line with the thoughts of local administrator Beth, who said, "I believe that this policy also ensures that children receive developmentally appropriate instruction, banning worksheets, standardized testing, etc. that now has made its way into kindergarten." As Jean Jacques Rousseau (1762, p. 42) wrote in Emile, "let him know nothing because you have told him, but because he has learnt it for himself."

Another concern is the recognition of the document by the interviewees. In order for the policy to be successful everyone involved must understand what it says. Living the document is not enough.

\section{Implications for policy makers}

Worldwide, policymakers have taken an increased interest in early childhood education. These policies assist in defining and regulating the fields of early childhood (Organisation for economic cooperation and development, 2006). They have increased training, defined curriculum and assessment, and augmented access to early childhood education. The focus for these early childhood educators is on ensuring that policy makers understand the distinctiveness of this developmental age bracket (C. P. Brown, 2007).

From my perspective, Policy 2525 has implications for policy makers as they develop future educational policies. First, the authors of the policy reviewed studies that involved brain research, which provided the government officials support and understanding of the importance of early childhood education. Second, the research laid a framework for them to write the policy; thus allowed the policy to be very specific. The specificity of the policy provides a 
strong framework for people to follow and allows for minimal wiggle room regarding interpretation. While this may have a negative connotation, the policy is grounded, for the most part, in developmentally appropriate practice and research based ideas. Third, the policy requires preschool teachers to hold a 4 - year degree in early childhood and child development. Last, ongoing monitoring should be included in the policy as it continues to grow. As has been noted, policy makers should "put forward a vision of early learning that represents and respects the teacher, the students, the families and the community-at-large" (C. Brown \& Mowry, 2009, p. 177).

\section{Funding}

Funding is, and always will be, an issue that surrounds educational policy. Economic changes have influenced the introduction of state governments into early childhood education. . State legislatures are helping "secure child care that is both affordable and supportive of their child's development" (Culkin, Groginsky, \& Christian, 1997). “A high-quality, public pre-k program cannot be created solely through better use and coordination of federal funds. State policymakers must allocate substantial state funds that can be increased over time," said Diane Stone, a senior fellow at the Washington Appleseed Center for Law in the Public Interest ("Funding preschool programs," 2007).

President Obama's budget proposal seeks to increase federal spending by $\$ 500$ million to match state and district Title I money for pre-kindergarten programs. He also is proposing an additional \$300 million to help states better integrate early childhood programs (A. Klein, 2009).

There are numerous possibilities for funding preschool programs. Currently, some states tax cigarettes and/or alcohol, and some create a lottery funded preschool program. West Virginia's state aid formula, an enrollment driven formula, funds the majority of the state's 
preschool classrooms. This formula adjusts according to the number of children enrolled which provides enough yearly funding.

\section{Relationships}

David Hargreaves (2003) pointed out that collaboration among districts and educators promotes the creation, validation, and spreading of knowledge about what works in schools and classrooms. He calls this "working laterally" within a region to allow for the transfer of innovation and best practices so that educators can "get on with the job" of improving student learning. In order to achieve success, all entities must share a common vision and mission. "Collaborative culture could improve curriculum and lead to increased student learning when leaders successfully promote high expectations, a spirit of inquiry, and an unwavering focus on learning for both students and adults," wrote Robert Garmston (2007). "Working together to address challenging issues and using valuable lessons they learned together, rather than struggling with issues individually" (Williams, Tabernik, \& Krivak, 2009) will add value to the implementation.

According to Ivery (2008, p. 53), "Policies often do not provide specific guidelines on how to implement the collaboration component." This can pose a problem if there is a previously bad relationship or the skills to "initiate and sustain relationships between organizations" (Ivery, 2008, p. 54) are not present. Many policies fail to recognize the essential impact of entities' collaboration and the impact this has upon the enacted policy. Sachwald and Eley (2008, p. 38) write that, referencing agencies, "have the resources to motivate and facilitate the change process." This motivation can be an extremely powerful and positive position that collaborative agencies hold. 
Relationships are the key factor in collaboration. Any human relationship needs communication; collaborative relationships are no exception. Indisputable is that interaction improves communication effectiveness (Knewstubb \& Bond, 2009, p. 180). The problem lies in whether all parties have a shared understanding. Second, mutual trust needs to be established. Third, a collaborative culture must be nurtured and protected. Every member has something to contribute to create an effective team (Steele \& Boudett, December 2008-January 2009, p. 56). This is a reminder that success does not happen in isolation (Hord \& Hirsh, 2009, p. 22) but collectively. An often troubling realization is that the organizations do not agree among themselves about common goals and objectives. The goal is to find explicit agreement from all parties involved.

In The fifth discipline: The art and practice of learning organization, Senge wrote that organizations must "continually expand their capacity to create the results they truly desire, where new and expansive patterns of thinking are nurtured, where collective aspiration is set free, and where people are continually learning to see the whole together" (Williams et al., 2009). Their time together must be reflective. This will shape relationships and allow for the ultimate collaboration experience.

Collaboration with Head Start and child care centers is key in the success of Policy 2525. Head Start is vital in providing a history for preschool education. They are research proven. Holly reiterates the importance of Head Start,

Head Start has always had to meet those performance standards, Head Start has always been monitored on a fairly regular basis, because Head Start became a partner in this whole process, it looks 
completely different in the school system, moving $\mathrm{K}$ down a grade.

It is much more defined.

Child care centers provide an opportunity for families to participate in a public school system mandated curriculum while simultaneously meeting the families childcare needs.

Heather notes the need for the collaborative component,

I think is good to partner with other groups in Camden County so that families that need child care or choose to go to a more private Pre-K kind of look that we could also partner with them and that way insure there is a continuity in Camden County schools because we know that all these children are coming into our kindergarten programs in most respects so we want them to have the same experience as much as possible, not to cookie cutter but to a certain extent control and have children with the same experiences and that way working families can have their children in child care centers and feel they are getting the same thing that they would get if they were in the school.

The essential piece is that collaboration only works if mutually beneficial. "Counties that have really strong, lasting relationships with their collaborative partners have excellent programs," stated Hilton, an early childhood state administrator. 


\section{Ratio}

According to the NAEYC criteria (NAEYC, 2005), preschool classrooms should have up to twenty children and there should be two teachers in the room at all times. Due to the development and age of the children in the classroom, it is not appropriate to have only two teachers present per twenty children. It creates potentially hazardous situation on many levels. Physically, if the ratio is exceeded, children may get hurt due to inadequate supervision. This is especially significant during eating and restroom times; thus, an improper ratio becomes a safety issue. Academically, children are not provided enough one-on-one or small group attention. Emotionally, there is a reduced amount of time spent developing positive relationships. When ratios are high, positive interaction between teacher and student decrease (R. Pianta et al., 2005).

\section{Infrastructure}

Webster's New World Dictionary (2009) defines infrastructure as "the underlying foundation or basic framework (as of a system or organization); the resources (as personnel, buildings, or equipment) required for an activity." Clearly, the policy provides a foundation for preschool that recognizes the imperative resources for success. For the purposes of this study, infrastructure includes teacher education, the early childhood building, bus transportation, and early childhood curriculum. Kagan \& Cohen (1997), Gormley (1995), and Bredekamp (1987) agree that high quality programs should include well-trained personnel, an attractive environment, and developmentally appropriate materials.

In President Barack Obama's first speech regarding education, he said, "recruiting, preparing, and rewarding outstanding teachers" will be one of the new administration's top priorities. The priorities set forth in the "stimulus package will return attention to preparation and retention of highly qualified teachers" (Fraser, 2009). Teachers' beliefs lie "at the very heart 
of teaching” (D. M. Kagan, 1992, p. 85)

Teacher education is integral part of early childhood education. In Scandinavian countries, teachers are required to obtain three years of graduate level teaching preparation (L. Darling-Hammond \& Haselkorn, 2009). Preparation in a school connected to the university, pedagogical coursework focusing on classroom research, and meeting the needs of struggling learners are the focus of the teacher training. The government foots the bill which also includes a living stipend. In Singapore, an undergraduate teaching degree is subsidized and includes a salary during training. In other countries, teacher salaries are comparable to other occupations so that highly qualified teachers are recruited. President Obama’s teaching agenda includes $\$ 6$ billion. Service scholarships and investments in performance based preparation, as well as mentoring and professional development in the context of new career ladders, are the foundation of this agenda. His recently enacted stimulus package contains $\$ 100$ million to support teacher residencies and other innovative preparation programs (L. Darling-Hammond \& Haselkorn, 2009).

There is a growing awareness of the need to focus on teacher education. This movement will lessen the notion of early childhood teachers as caregivers and boost the professionalization of the field (Cochran-Smith, 2005; L. Klein \& Knitzer, 2006; Neugebauer, 2008).

\section{Research Questions}

At this point, the research questions will be revisited in order to summarize the ideas presented in reference to the questions.

\section{Research Question 1}

How do participants define their roles in the implementation of universal preschool education (Policy 2525) in West Virginia? 
The interviewees were clearly able to state what their positions were in relation to the policy, even if they were not familiar with the document. For the most part, the early childhood teachers and local administrators were not able to recite or identify their job description as it relates to the policy. In fact, the majority of them had no recollection of seeing their job description. Overall, the roles of the interviewees ranged from implementing the policy, assisting teachers in following the policy, teaching a classroom of early childhood children, coordinating early childhood at the state level, working with collaborative partners, or training and assessment for the policy.

\section{Research Question 2}

What are the participants' understandings of the goals of universal preschool education (Policy 2525) West Virginia?

There was universal agreement on the answer to this question. Every interviewee deemed the most important goal was a developmentally appropriate, quality education for all 35-year-olds in the state of West Virginia. This is not a mandatory requirement but an opportunity available, if families wish to participate. Universality is to be fully implemented as of the 2012-2013 school year.

\section{Research Question 3}

What are the participants' perspectives of the benefits and challenges of universal preschool education (Policy 2525) in West Virginia?

All families in West Virginia will now have the opportunity to attend a quality educational program. For some time, we have serviced only children who are low income, but there are families that are able to afford a private preschool education. This policy bridges the gap between the two groups and provides an opening for all children, regardless of income, to 
attend a developmentally appropriate preschool setting. Another benefit is the collaboration with Head Start. Since Head Start has strong roots, preschool programs are especially well-developed in counties that previously held Head Start in the public school system. This Head Start relationship provides a well-established foundation for preschool education in those counties.

While all participants spoke positively about the goal of Policy 2525 , they also acknowledged problems. First, teacher-student ratio is an issue. While NAEYC states that 1:10 teacher to student ratio is appropriate, it does not take into consideration special needs children who may require extra attention. Also, if facilities are not appropriate, tasks such as simply escorting a child to the bathroom may break the ratio. Second, educating all parties, including administrators, becomes a priority. If principals have a limited understanding of preschool children, it may pose numerous problems with regard to facilities, behavior, and curriculum. Also, if families are aware of preschool settings within their community, they are likely to inquire and enroll their children. However, if they are not versed in preschool education, they may not feel comfortable sending their children.

\section{Research Question 4}

How is universal preschool (Policy 2525) being implemented in West Virginia according to West Virginia educators?

There is a hierarchy of people that impacts implementation. The state administrators deal directly with the county administrators. The county administrators are responsible for guiding the school administrators and, sometimes, the teachers. The school administrators are responsible for the early childhood teachers. While there is a chain of command, the policy establishes the preschool framework and provides minimal wiggle room for interpretation. The biggest issue seemed to concern school administrators, as they often do not have an educational 
background in early childhood education. Therefore, they may lack an understanding of the developmental appropriateness of the age group. Reportedly, school administrators often required inappropriate goals and objectives for the children.

\section{Research Question 5}

How does the implementation of the policy compare to the legislative intent of the policy?

The implementation is relatively congruent with the legislated policy. The overarching

benefit to an early education is in an appropriate environment and exposure to a variety of social situations where inquiry is occurring on a regular basis. Enriched environments are occurring much earlier with this enacted policy.

Preschool also provides an inclusive setting that allows all children to have an equal opportunity at education. The needs of the children are considered, but this does not determine whether they have a position in the classroom. The equity in education is imperative.

Once upon a time, the kindergarten classroom resembled the current day preschool classroom. Preschool has replaced kindergarten with a developmentally appropriate curriculum, which means eliminating worksheets and standardized testing. The research which is the foundation of the policy, is supporting what the children are doing in the classroom on a daily basis. Thus, because the policy is based on research, it will make a long term impact upon the education of the children.

The community often perceives early childhood education as babysitting; this policy reinforces the quality required in preschool education and links preschool as an integral part of education. As the implementation continues, community members will begin to understand the benefit. 


\section{Future Research}

There are several possibilities for future research. First, the idea of collaboration surfaced in many interviews. Often the success of an organization depends upon collaborating with other organizations, such as the case of public schools collaborating with Head Start, child care, and DHHR to provide the best whole preschool education. Hence, I would like to view public schools' collaboration within the context of relationships. Specifically, looking into how relationships and prior experiences impact collaboration.

Second, how is the living policy actually being carried out? Even though there was a common understanding of the policy among all groups they perceived it to be successful whether it was within the classroom, the school, the county, or the state the problem is that these are subjective opinions and everyone thinks that everything is ok. My question is this: is it really? The teachers were not observed in their classroom, are the teachers providing a developmentally appropriate curriculum? Is the curriculum student led and emergent? Are different types of assessment used and are they ongoing? This research will be a continuation of this dissertation.

Third, education cut-backs are occurring throughout the United States. Schools, policies, and programs are going to be required to justify their expenditures in order to continue receiving funding. An exploration of the cost benefit analysis of Policy 2525 would be useful to present to policy makers and school systems. This would validate Policy 2525's benefit to students, families, and the community.

Lastly, I would like to explore the influence principals have upon preschool classrooms within their school. Documenting this interaction in a qualitative study would examine the importance of relationships on multiple levels. The success of a preschool classroom can be largely dependent upon the positive or negative attitude of the principal. His or her outlook can 
impact funding, highly qualified teacher retention, relationships, and many other factors. Such research may provide a better understanding of the preschool classrooms that are flourishing as well as those which are not.

\section{Summary}

This study found that one's perception of Policy 2525 is based on his or her experiences surrounding the policy. It is important to remember that all interviewees deemed the primary goal of Policy 2525 to be access to high quality education for all West Virginia preschoolers. In order to take Policy 2525 to a unified implementation stage, people who implement the policy at different levels must communicate regularly. Then, information regarding the policy and its implementation must be presented to West Virginia government officials by teachers, principals, county administrators, and state administrators. The perspectives of persons involved must be respected and considered. The challenge for policy makers and educators is to realign the existing system and incentives that shape school organizations, teachers' practices, role expectations, and assumptions, so that they support student and teacher learning (L. DarlingHammond \& McLaughlin, 1995).

This dissertation has further opened my eyes to aspects of early childhood education that I never before considered. As a teacher, I never focused on funding issues, collaboration, or infrastructure issues. In the future, I will analyze the framework that surrounds my employment, and I will understand that it is there for a reason and may provide answers to many questions. Also, I will attempt to consider all perspectives when forming my opinions.

Preschool is here and, hopefully, it is here to stay. We have two choices--to become advocates or to become spectators. I choose to be an advocate. 


\section{BIBLIOGRAPHY}

Abbott v Burke IV, 149 N.J. 145 (New Jersey Supreme Court 1998).

Abbott v Burke V, 153 N.J. 480 (New Jersey Supreme Court 1997).

Abbott v Burke VI, 163 N.J. 95 (New Jersey Supreme Court 2000).

Ackerman, D. J. (2004). States' efforts in improving the qualifications of early care and education teachers. Educational Policy, 18(2), 311-337.

American Association of Colleges for Teacher Education (AACTE) Focus Council on Early Childhood Education. (2004). The early childhood challenge: Preparing high-quality teachers for a changing society. Paper presented at the American Association of Colleges for Teacher Education (AACTE) Focus Council on Early Childhood Education.

Ames, L. B. (1989). Arnold Gesell: Themes of his work. New York: Human Sciences Press.

Barbarin, O., Bryant, D., McCandies, T., Burchinal, M., Early, D., Clifford, R., et al. (2006). Children in public pre-K: The relation of family life, neighborhood quality, and socioeconomic resources to early competence. American Journal of Orthopsychiatry, $76(2), 265-276$.

Barbarin, O. A., McCandies, T., Early, D., Clifford, R. M., Bryant, D., Burchinal, M., et al. (2006). Quality of pre-K: What families are looking for in public sponsored programs. Early Education and Development, 17(4), 619-642.

Barnett, W. S. (2004). Better teachers, better preschools: Student achievement linked to teacher qualifications. Preschool Policy Matters, 2, 1-11.

Barnett, W. S., \& Belfield, C. R. (2006). Early childhood development and social mobility. Future of Children, 16(2), 73-98. 
Barnett, W. S., Brown, K., \& Shore, R. (2004). The universal vs. targeted debate: Should the United States have preschool for all? New Brunswick.

Barnett, W. S., \& Hustedt, J. T. (2003). Preschool: The most important grade. Educational Leadership, 60(7), 54-57.

Barnett, W. S., \& Yarosz, D. J. (2007). Who goes to preschool and why does it matter? New Brunswick: Rutgers Graduate School of Education.

Beatty, B. (1997). Preschool education in America: The culture of young children from the colonial era to the present. New Haven: Yale University Press.

Belfield, C. R. (2006). The fiscal impacts of universal pre-k: Case study analysis for three states [Electronic Version]. Retrieved March 20, 2008 from http://www.ced.org/docs/report/report_ivk_belfield2005.pdf.

Bogard, K., Traylor, F., \& Takanishi, R. (2008). Teacher education and PK outcomes: Are we asking the right questions. Early Childhood Research Quarterly, 23, 1-6.

Bredekamp, S. (1987). Developmentally Appropriate Practice in Early Childhood Education Programs Serving Children From Birth Through Age 8. Washington, DC: National Association for the Education of Young Children.

Bredekamp, S., \& Copple, C. (1997). Developmentally appropriate practice in early childhood programs. Washington, DC: National Association for the Education of Young Children Brown, C., \& Mowry, B. (2009). Preparing for change: A case study of successful alignment between a pre-k program and K-12 education. Childhood Education Journal, 85(3), 173178.

Brown, C. P. (2007). It's more than content: Expanding the conception of early learning standards. Early childhod research and practice, 9(1). 
Bruner, J. (2009). Jerome Bruner. Retrieved April 26, 2009, from http://findarticles.com/p/articles/mi_g2699/is_0000/ai_2699000048/

Burts, D. C., Hart, C. H., Charlesworth, R., \& Kirk, L. (1990). A comparison of frequencies of stress behaviors observed in kindergarten children in classrooms with developmentally appropriate versus developmentally inappropriate instructional practices. Early Childhood Research Quarterly, 5(3), 407-423.

Bushouse, B. (2006). West Virginia collaboration for creating universal prekindergarten. Public Administration Review, 66(1), 154-155.

Bushouse, B. (2007). Universal preschool policy change in the pioneer states. Paper presented at the American Political Science Association. from http://www.allacademic.com//meta/p_mla_apa_research_citation/2/1/0/0/1/pages210016/ p210016-1.php.

California Department of Education. (2005). Getting results update 5-Student health, supportive schools and academic success. Sacramento: CDE Press.

Calman, L. J., \& Tarr-Whelan, L. (2005). The economic impacts of child care and early education: Financing solutions for the future. Paper presented at the Legal Momentum's Family Initiative and MIT Workplace Center.

Center, E. L. (2007, 2007). Abbott Preschool Program. Retrieved March 30, 2008, from http://www.edlawcenter.org/ELCPublic/AbbottPreschool/AbbottPreschoolProgram.htm

Center on the developing child at Harvard University. (2007). A science-based framework for early childhood policy: Using evidence to improve outcomes in learning, behavior, and health for vulnerable children. Retrieved February 6, 2009 
Chen, J.-Q., Horsch, P., DeMoss, K., \& Wagner, S. L. (2004). Effective partnering for school change: Improving early childhood education in urban classrooms. New York: Teachers College Press.

Clifford, R. M., Barbarin, O., Chang, F., Early, D. M., Bryant, D., Howes, C., et al. (2005). What is pre-kindergarten? Characteristics of public prekindergarten programs. Applied Developmental Science, 9(3), 126-143.

Cochran-Smith, M. (2005). Studying teacher education: What we know and need to know Journal of Teacher Education, 56, 301-306.

Cohen, M. (2008). Some images of magnificence. Childhood Education Journal, 85(1), 33-38.

Comer, J. P. (1980). School power: Implications of an intervention project. New York: The Free Press.

Committee for Economic Development. (2002). Preschool for all: Investing in a productive and just society. Washington, DC: Committee for Economic Development.

A comprehensive study of the programs governance and administration of regional education service agencies. (2006).). Charleston, WV: West Virginia Deparment of Education.

Cotton, K., \& Conklin, N. F. (1989). Research on Early Childhood Education. School Improvement Research Series (SIRS).

Culkin, M., Groginsky, S., \& Christian, S. (1997). Building blocks: A legislators' guide to child care policy-Executive summary: National Conference of State Legislatures.

Dahlberg, G., Moss, P., \& Pence, A. (1999). Beyond quality in early childhood education and care: Postmodern perspective. London: Falmer Press.

Darling-Hammond, L. (2006). Securing the right to learn: Policy and practice for powerful teaching and learning. . Educational Researcher, 35, 13-24. 
Darling-Hammond, L., \& Haselkorn, D. (2009). Reforming teaching: Are we missing the boat? Education Week, 28(27).

Darling-Hammond, L., \& McLaughlin, M. (1995). Policies that support professional development in an era of reform. Phi Delta Kappan, 76(8).

Davis, J. W., \& Bauman, K. J. (2008). School enrollment in the United States: 2006: U.S. Census Bureau.

Dittmer, J. (1994). Local people: The struggle for civil rights in Mississippi. Chicago: University of Illinois Press.

Duncan, G., Ludwig, J., \& Magnuson, K. A. (2007). Reducing poverty through preschool interventions. . Future of Children, 17(2), 143-160.

Early childhood education programs, West Virginia Senate(2002).

Early childhood education: An international encyclopedia (Ed.)^(Eds.). (2007) (Vols. 1 A-D). Westport, CT: Praeger.

Early, D. M., Bryant, D. M., Pianta, R. C., Clifford, R. M., Burchinal, M. R., Ritchie, S., et al. (2006). Are teachers' education, major, and credentials related to classroom quality and children's academic gains in pre-kindergarten? . Early Childhood Research Quarterly, 21, 174-195.

Early, D. M., Maxwell, K. L., Burchinal, M., Alva, S., Bender, R. H., Bryant, D., et al. (2007). Teachers' education, classroom quality, and young children's academic skills: Results from seven studies of preschool programs. Child Development, 78, 558-580.

Early, D. M., \& Winton, P. J. (2001). Preparing the workforce: Early childhood teacher preparation at 2- and 4-year institutions of higher education. Early Childhood Research Quarterly, 16, 285-306. 
Edwards, S. (2005). Children's learning and developmental potential: examining the theoretical informants of early childhood curricula from the educator's perspective. Early Years, 25(1), 67-80.

Eisner, E. W. (1991). The enlightened eye: Qualitative inquiry and the enhancement of educational practice. New York: Macmillan Publishing Company.

Eyre, E. (2002). State to require annual bus time reports. Charleston Gazette.

Fairclough, N. (1989). Language and power. New York: Longman.

Follari, L. M. (2007). Foundations and best practices in early childhood education. Upper Saddle River, New Jersey: Pearson Merrill Prentice Hall.

Fraser, J. W. (2009). Education schools need a gold standard. Chronicle of Higher Education, $55(31)$

Funding preschool programs. (2007). Retrieved May 17, 2009, from http://www.sopriswest.com/newsletters/fundingnews_jan07.htm

Gable, R. A., Mostert, M. P., \& Tonelson, S. W. (2004). Assessing professional collaboration in schools: Knowing what works. Preventing school failure, 48(3), 4-8.

Gammage, P. (2006). Early childhood education and care: Politics, policies and possibilities. Early Years: Journal of International Research \& Development, 26(3), 235-248.

Garmston, R. (2007). Right way to begin depends on where you are right now. National Staff Development Council Newsletter, 28(1).

Gee, J. P. (2005). An introduction to discourse analysis: Theory and method (2nd ed.). New York: Routledge.

Gesell, A. (1933). Maturation and the patterning of behavior. In C. Murchison (Ed.), A handbook of child psychology (2nd ed.). Worcester: Clark University. 
Ginsburg, K. R., Committee on Communications, \& Committee on Psychosocial Aspects of Child and Family Health. (2007). The importance of play in promoting health child development and maintaining strong parent-child bonds. Pediatrics, 119(1), 182-191.

Glesne, C., \& Peshkin, P. (1992). Becoming qualitative researchers: An introduction. New York: Longman.

Golafshani, N. (2003). Understanding reliability and validity in qualitative research. The Qualitative Report, 8(4), 597-607.

Gormley, W. T. (1995). Everybody's children: Child care as a public problem. Washington, DC: Brookings Institution.

Gormley, W. T., \& Phillips, D. (2003). The effects of universal pre-k in Oklahoma: Research highlights and policy implication.

Greenberg, M. H., Levin-Epstein, J., Hutson, R. Q., Ooms, T. J., Schumacher, R., Turetsky, V., et al. (1996). The 1996 welfare law. Key elements and reauthorization issues affecting children. The Future of Children, 12(1), 27-57.

Greenberg, P. (1990). The devil has slippery shoes, A biased biography of the Child Development Group of Mississippi. New York: Macmillan and Company.

Hargreaves, D. H. (2003). Working laterally: How innovation networks can make an education epidemic: Department for Education and Skills.

Heckman, J. L. (2006). The case for investing in disadvantaged young children Paper presented at the Forum on Building the Economic Case for Investments in Preschool.

Hoepfl, M. C. (1997). Choosing qualitative research: A primer for technology education researchers. Journal of technlogy education, 9(1), 47-63. 
Hofer, M. R. (1897). Imagination in children: Miss M.R. Hofer describes the value of the kindergarten system in education. The New York Times, p. 10.

Holzer, H., Schanzenbach, D., Duncan, G., \& Ludwig, J. (2007). “The Economic Costs Of Poverty In The United States: Subsequent Effects Of Children Growing Up Poor" Paper presented at the Center for American Progress.

Hord, S. M., \& Hirsh, S. A. (2009). The principal's role in supporting learning communities. Educational Leadership, 66(5), 22-23.

Horm-Wingerd, D., Hyson, M., \& Karp, N. (2000). Introduction: In New teachers for a new century: The future of early childhood professional preparation. Paper presented at the National Institute on Early Childhood Development and Education, US Department of Education.

Howes, C., Burchinal, M., Pianta, R., \& Bryant, R. (2008). Ready to learn? Children's preacademic achievement in pre-Kindergarten programs. Early Childhood Research Quarterly, 23(1), 27-50.

Improving Head Start for School Readiness Act, House of Representatives, 110th Sess.(2007). infrastructure (Ed.) (2009) Merriam-Webster Online Dictionary. Internal Revenue Service United States Department of the Treasury. (2008, March 4). Claiming the child and dependent care credit. Retrieved February 14, 2009, from http://www.irs.gov/newsroom/article/0,,id=106189,00.html

International Early Childhood Policy. (2008, August 8). Retrieved October 2, 2008, from http://childstudycenter.yale.edu/international/index.html

Isenberg, J. P., \& Quisenberry, N. (2002). Play: Essential for all children. Paper presented at the Association for Childhood Education International. 
Ivery, J. (2008). Policy mandated collaboration. Journal of Sociology \& Social Welfare, 35(4), 53-70.

Jackson, L., West Virginia State Senator. (2005). Interview by author. Charleston, WV.

Jalongo, M., Fennimore, B., Pattnaik, J., Laverick, D., Brewster, J., \& Mutuku, M. (2004).

Blended perspectives: A global vision for high-quality early childhood education. Early Childhood Education Journal, 32(3), 143-155.

Janks, H. (1997). Critical discourse analysis as a research tool. Discourse, 18(2), 329-342.

Johnson, M. A. (2005). Hull House. Retrieved February 12, 2009, from http://www.encyclopedia.chicagohistory.org/pages/615.html

Kagan, D. M. (1992). Implications of research on teacher belief. Educational Psychologist, 27, $65-90$.

Kagan, S. L., \& Cohen, N. C. (1997). Not by chance (The quality 2000 initiative). New Haven, CT: Bush Center in Child Development and Social Policy.

Kagan, S. L., \& Cohen, N. E. (Eds.). (1996). Reinventing early care and education A vision for a quality system. San Francisco: Jossey-Bass.

Katz, L. G. (1999). Curriculum disputes in early childhood education. ERIC Digest, 1-7.

Kent, C., Hamilton, P., Risch, C., Sowards, K., \& Rusalkina, V. (2005). The economic impact of early child development programs in West Virginia. Huntington: Marshall University Center for Business and Economic Research

Kent, C., Price, J., Springer, E., Spratt, G., Shepherd, J., \& Al, S. (2009). Comprehensive improvements in early childhood policies for West Virginia. Huntington: Marshall University.

Klein, A. (2009). Obama budget proposes increase for education. Education Week, 28(31), 20. 
Klein, L., \& Knitzer, J. (2006). Pathways to early school success: Effective preschool curricula and teaching strategies. Paper presented at the National Center for Children in Poverty.

Kleinman, S. (1999). Essaying the personal, making sociological stories stick. In B. Glasner \& R. Hertz (Eds.), Qualitative sociology as everyday life. Newbury Park: Sage Publications.

Knewstubb, B., \& Bond, C. (2009). What's he talking about? The communicative alignment between a teacher's intentions and students' understandings. Higher Education Research \& Development, 28(2), 179-193.

Li, Y. L. (2006). Classroom organization: Understanding the context in which children are expected to learn. . Early Childhood Education Journal, 34(1), 37-43.

Lim, C., \& Able-Boone, H. (2006). Diversity competencies within early childhood teacher preparation: Innovative practices and future directions. Journal of Early Childhood Teacher Education, 26, 225-238.

Lobman, C., Ryan, S., \& McLuaghlin, J. (2005). Reconstructing teacher education to prepare qualified preschool teachers: Lessons from New Jersey. [Electronic Version]. Early Childhood Research and Practice, 7. Retrieved March 20, 2008 from http://ecrp.uiuc.edu/v7n2/lobman.html.

Luke, A. (Ed.) (2008) International Encyclopedia of the Sociology of Education. Queensland, Australia: Elsevier Science Ltd.

Malaguzzi, L. (Ed.). (1998). History, ideas and basic philosophy: an interview with Lella Gandini, in: Edwards, C., Gandini, L., \& Forman, G. The hundred languages of children: The Reggio Emilia approach: Advanced reflections (2nd ed.). Greenwich, CT: Ablex Publishing Corporation. 
McCain, J., \& Palin, S. (2008). Education. Retrieved September 13, 2008, 2008, from http://www.johnmccain.com/Informing/issues/19ce50b5-daa8-4795-b92d92bd0d985bca.htm

Merriam, S. B. (2002). Qualitative research in practice Examples for discussion and analysis. San Francisco: Jossey-Bass.

Miller, R., \& Pedro, J. (2006). Creating respectful classroom environments. Early Childhood Education Journal, 33, 293-299.

Morrison, G. S. (1998). Early Childhood Today. New Jersey: Merrill.

Murray, E. R., \& Smith, H. B. (2003). The child under eight: Public Domain Books.

Myers, V. L., Griffin, H. C., Telekei, J., Taylor, J., \& Wheeler, L. (1998). Birth Through Kindergarten Teacher training. Childhood Education, 74(3), 154-159.

NAEYC. Making a difference: Excellence in early childhood education. Washington, DC.

NAEYC. (2005). Teacher-child ratios within group size. Retrieved August 21, 2008, from http://www.naeyc.org/academy/criteria/teacher_child_ratios.html

National Center for Early Development \& Learning. (2001). Public school pre-K programs: National survey of states [Electronic Version]. Education Week, 21 from http://www.edweek.org/sreports/qc02/tables/17teachqual-t1.pdf.

National Forum on Early Childhood Program Evaluation. (2007). A science based framework for early childhood policy: Using evidence to improve outcomes in learning, behavior, and health for vulnerable children Cambridge: Harvard University.

National Head Start Association. (2007). Head Start Basics: National Head Start Association. National Institute for Early Childhood Research (NIEER). (2007). The State of Preschool 2007: Rutgers Graduate School of Education. 
Neugebauer, R. (2008). Challenges facing early childhood programs worldwide. Exchange: The Early Childhood Leaders' Magazine Since 1978, 181, 6-27.

New, R. (2007). Reggio Emilia as cultural activity theory in practice. Theory Into Practice, $46(1), 5-13$.

Organisation for economic cooperation and development. (2006). Starting strong II: Early childhood education and care. Retrieved May 17, 2009, from http://www.oecd.org/document/63/0,3343,en_2649_39263231_37416703_1_1_1_1,00.ht $\underline{\mathrm{ml} \# \mathrm{ES}}$

Patton, M. Q. (2002). Qualitative Research \& Evaluation Methods (3rd ed.). Thousand Oaks, CA: Sage Publications, Inc.

Peltzman, B. R. (1998). Pioneers of early childhood education A bio-bibliographical guide. Westport, Connecticut: Greenwood Press.

Perez-Johnson, I., \& Maynard, R. (2007). Interventions to prevent academic failure. Peabody Journal of Education, 82(4), 587-616.

Perkins, D. (1992). Smart schools Better thinking and learning for every child. New York: Free Press.

Pianta, R., Howes, C., Burchinal, M., Bryant, D., Clifford, R. M., Early, D. M., et al. (2005). Features of pre-kindergarten programs, classrooms, and teachers: Prediction of observed classroom quality and teacher-child interactions. Applied Developmental Science, 9(3), 144-159.

Pianta, R. C. (2006). Standardized classroom observations from pre-k to 3rd grade: A mechanism for improving access to consistently high quality classroom experiences and 
practices during the P-3 years. Retrieved April 6, 2008, from http://www.earlychildhoodrc.org.

Pini, M., \& Gorostiaga, J. (2008). Teacher education and development policies: Critical discourse analysis from a comparative perspective. International Review of Education, $54(3 / 4), 427-443$.

Pre-K Now. (2005-2008). Pre-K Now Facts Sheet. Retrieved September 3, 2008, from http://www.preknow.org/advocate/factsheets/snapshot.cfm.

Preventing crime with pre-kindergarten: A critical investment in West Virginia's safety. (2006).

Retrieved September 20, 2008, from

www.fightcrime.org/reports/PreKstate06/wvprekbrief.pdf

Ravitch, D. (1985). The troubled crusade: American education, 1945-1980. New York: Basic Books.

Read, M. (2007). Sense of place in child care environments. Early Childhood Education Journal, 34(6), 387-392.

Rhodes, E. (2000, March 28). Universal Preschool. New ideas for a new century Retrieved February 11, 2009, from http://www.tcf.org/Publications/Education/UniversalPreschool.pdf

Rippa, A. (1997). Education in a free society. An American history. New York: Longman.

Rousseau, J. J. R. (1762). Emile. New York: Basic Books.

Sachwald, J., \& Eley Jr., E. (2008). The c-crets of collaboration. Corrections Today, 70(2), 3843. 
Sacks, L., \& Ruzzi, B. B. (2005). Early childhood education: Lessons from the states and abroad: 2005. Paper presented at the New Commission on the Skills of the American Workforce.

Saluja, G., Early, D. M., \& Clifford, R. M. (2002). Demographic characteristics of early childhood teachers and structural elements of early care and education in the United States. Early Childhood Research and Practice, 4(1), 1-19.

Scott-Little, C., Kagan, S. L., \& Frelow, V. S. (2004). Inside the content: The breadth and depth of early learning standards. Greensboro: Institute of Education Sciences.

Seifert, K. (Ed.) (2004) Encyclopedia of Human Development. Thousand Oaks, CA: Sage Publishers.

Senate Bill 498, Senate(2009).

Steele, J. L., \& Boudett, K. P. (December 2008-January 2009). The collaborative advantage. Educational Leadership, 66(4), 54-59.

Steinmetz, A. (1983). The discrepancy evaluation model. In G. F. Madaus, M. S. Scriven \& D. L. Stufflebeam (Eds.), Evaluation models: Viewpoints on educational and human services evaluation. Boston: Kluwer-Nijhoff Publishing.

Stoney, L. (2004). Framing child care as economic development: Lessons from early studies.

Strong-Wilson, T., \& Ellis, J. (2007). Children and place: Reggio Emilia's environment as third teacher. Theory Into Practice, 46(1), 40-47.

Textor, M. R. (1998). International perspectives on quality child care. Early childhood Education Journal, 25(3), 167-171. 
The Association for the Supervision and Curriculum Development. (2007). The learning compact redefined: A call to action. Alexandria: Association for Supervision and Curriculum Development.

The Association for the Supervision and Curriculum Development. (2008). Whole child resolution tool kit. Retrieved March 9, 2009, from http://www.wholechildeducation.org/ United States Department of Education. (2008, September 11). U.S. Education Secretary Margaret Spellings Announces \$4.3 Million Early Reading First Grant for Des Moines Public Schools. Retrieved September 18, from http://www.ed.gov/news/pressreleases/2008/09/09102008.html

University, C. (2008). West Virginia demographics of young, poor children. New York City: National Center for Children in Poverty (NCCP).

US Census Bureau, \& Housing and Household Economic Statistics Division. (2005, August 29, 2006). Poverty Thresholds 2005. Retrieved August 28, 2008, from http://www.census.gov/hhes/www/poverty/threshld/thresh05.html

US Department of Health and Human Services, Administration for Children and Families, Administration on Children Youth and Families, \& Head Start Bureau. (2005). Biennial report to Congress: The status of children in Head Start programs.

Vinovskis, M. A. (2005). The birth of Head Start: preschool education policies in the Kennedy and Johnson administration. Chicago: The University of Chicago Press.

Votruba-Drzal, E., Li-Grining, C. P., \& Maldonado-Carreno, C. (2008). A developmental perspective on full-versus part-day kindergarten and children's academic trajectories through fifth grade. Child Development, 79(4), 957-978. 
Vygotsky, L. (1978). Mind in society: The development of higher psychological processes. Cambridge, MA: Harvard University Press.

Waite, S., \& Davis, B. (2006). Collaboration as a catalyst for critical thinking in undergraduate research. Journal of Further and Higher Education, 30(4), 405-419.

Weber, L. (1971). The english infant school and informal education. Englewood Cliffs, NJ: Prentice-Hall.

Wellman, D. (2006, July 11). Marshall's 21st century early childhood education task force receives $\$ 300,000$ from Benedum Foundation. Retrieved September 13, 2008, 2008, from http://www.marshalluniversityfoundation.com/news/article-300k.php

West Virginia Board of Education. (2006-2007). Annual Report.

West Virginia Department of Education. WV School Directory. Retrieved July 15, 2009 from http://wvde.state.wv.us/ed_directory/

White, L. A. (2004). Trends in child care/early childhood education/early childhood development policy in Canada and the United States. The American Review of Canadian Studies, 34, 6.

Williams, P., Tabernik, A. M., \& Krivak, T. (2009). The power of leadership, collaboration, and professional development: The story of the SMART Consortium. Education and Urban Society, 41(4), 437-456.

Winter, G. (2000). A comparative discussion of the notion of validity in qualitative and quanitative research. The Qualitative Report, 4(3\&4).

Women's share of labor force to edge higher by 2008. (2000). TED: The Editor's Desk Retrieved March 20, 2008, from http://www.bls.gov/opub/ted/2000/feb/wk3/art01.htm 
WV Department of Education. (2007, July 12, 2007). State board of education updates preschool policy. Retrieved March 19, 2008, from http://wvde.state.wv.us/news/1467/

Zeleny, J. (2008, September 10). If elected...Obama Looks to Lessons From Chicago in His National Education Plan. The New York Times.

Zigler, E., Gilliam, W. S., \& Jones, S. M. (2006). A vision for universal preschool education. New York: Cambridge University Press. 


\section{APPENDIX A}

\section{INTERVIEW QUESTIONS}

\section{Script for Study}

Good morning, good afternoon, good evening, thank you for participating in this research study. The purpose of the study is to look at West Virginia educators' perspective on the implementation of Policy 2525, the universal preschool policy. This study is being conducted in partial fulfillment of the requirements for my dissertation at West Virginia University. I would like to audiotape this interview in order to accurately represent what you say: may I have your permission to tape this interview? Before we begin I want to make sure you understand the following:

- Your responses will be kept anonymous or confidential, no time will your name be revealed during reporting.

- Your name will not be attached to either the tape or notes from this interview or to transcribed data.

- Your participation is entirely voluntary; You can choose to stop the interview at any time and you do not have to answer every question although information will be strengthened if you do.

- Your job status will not be affected by your refusal to participate or to withdraw from the study.

Thank you again for your willingness to participate in this study.

1. What is your position or title within the school system?

2. How does your position relate to universal preschool policy (Policy 2525)?

3. In your job description, is your involvement with universal preschool policy (Policy 2525) mentioned? Please provide the exact wording.

4. What are the goals of universal preschool policy (Policy 2525)?

5. What is your role in implementation of universal preschool (Policy 2525)?

6. How is universal preschool (Policy 2525) being implemented in your department, system, or school?

7. How is Policy 2525 carried out in the classroom?

8. What is the biggest benefit of universal preschool policy (Policy 2525)?

Describe. 
9. What is the biggest challenge of universal preschool policy (Policy 2525)? Describe.

10. How does Policy 2525 immediately benefit early childhood education?

11. What are the long term implications of Policy 2525 for children?

12. If revising universal preschool policy (Policy 2525), what suggestions would you have? 


\section{APPENDIX B}

\section{Topic-Participant Breakdown}

\begin{tabular}{|c|c|}
\hline Question & Participant \\
\hline 1.What is your position or title in the school system? & $\begin{array}{l}\text { Policy-NA } \\
\text { Early childhood teachers-NA } \\
\text { Local administrators-NA } \\
\text { County administrator-NA } \\
\text { State administrator-NA }\end{array}$ \\
\hline $\begin{array}{l}\text { 2.How does your position relate to universal preschool policy (Policy } \\
\text { 2525)? }\end{array}$ & $\begin{array}{l}\text { Policy-NA } \\
\text { Early childhood teachers-care \& educate } 3-5 \text { yr olds, spec needs, HS, implement } \\
\text { creative curriculum } \\
\text { Local administrators-assist teacher, remain current on policy } \\
\text { County administrator-implementation } \\
\text { State administrator- training, evaluation, overseeing }\end{array}$ \\
\hline $\begin{array}{l}\text { 3.In job description, is your involvement with universal preschool } \\
\text { policy (Policy 2525) mentioned? Please provide the exact wording. }\end{array}$ & $\begin{array}{l}\text { Policy-NA } \\
\text { Early childhood teachers-do not know } \\
\text { Local administrators-training and monitoring } \\
\text { County administrator-implement policy } \\
\text { State administrator-mandating, revising policy, implementing policy }\end{array}$ \\
\hline 4.What are the goals of universal preschool policy (Policy 2525)? & 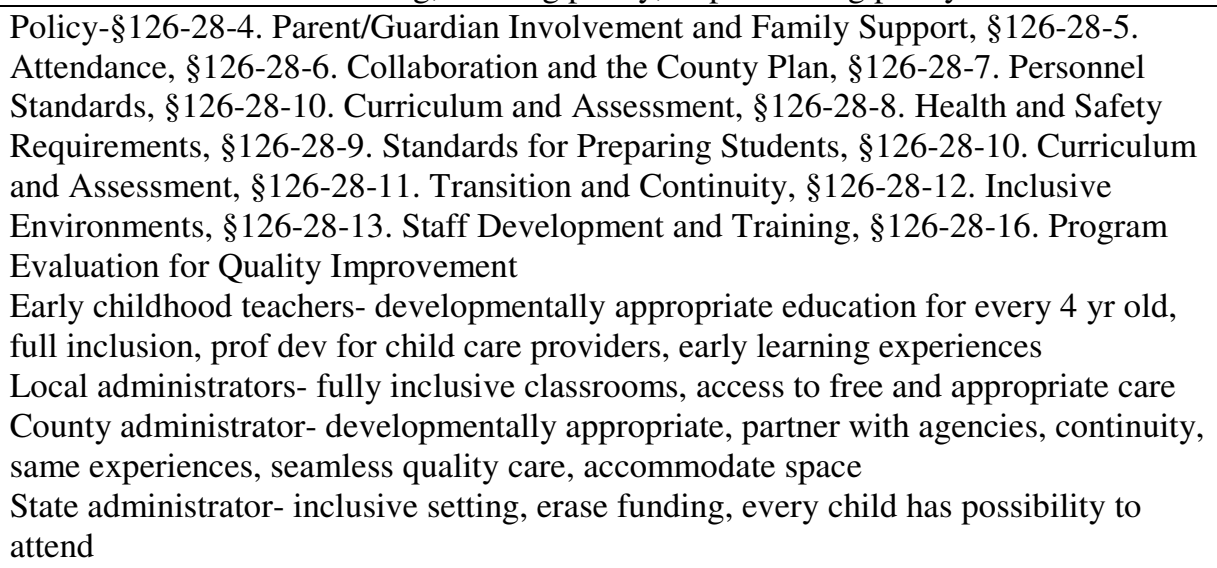 \\
\hline
\end{tabular}




\begin{tabular}{|c|c|}
\hline $\begin{array}{l}\text { 5.What is your role in implementation of universal preschool (Policy } \\
2525) \text { ? }\end{array}$ & $\begin{array}{l}\text { Policy-7.1 teachers employed in a WV Pre-k classroom and hired by the LEA must } \\
\text { hold the appropriate license issued by the WVDE. (See } 7.1-7.7 \text { for specifics), See } \\
6.1-6.14 \\
\text { Early childhood teachers-dictated what to do, provider of preschool services, learning } \\
\text { facilitator } \\
\text { Local administrators-administer ECERS, write improvement plans, monitored, file } \\
\text { reviews, set goals w/teachers } \\
\text { County administrator-oversee prek plan, work w/partners, contracts w/child care } \\
\text { partners, write plan, implement policy, direct policy } \\
\text { State administrator- equitable program for all 3-4 yr olds, quality, research based } \\
\text { practice, experiential learning, developmentally relevant }\end{array}$ \\
\hline $\begin{array}{l}\text { 6.How is universal preschool (Policy 2525) being implemented in } \\
\text { your department/system/school? }\end{array}$ & $\begin{array}{l}\text { Policy-6.1-6.14, 10.1-10.6 } \\
\text { Early childhood teachers- } 2 \text { classes, work collaboratively b/higher special needs, co } \\
\text { teaching, principals needs more training, facilitator } \\
\text { Local administrators-every } 4 \text { yr old not getting same service, levels of implementation } \\
\text { different, all classes fully inclusive, ECERS used as resource for change, special } \\
\text { ed/county helps fund materials } \\
\text { County administrator-HS standards and partnering in prek, law, negotiate contracts, } \\
\text { seek approval, pay, funding, just me } \\
\text { State administrator-prek steering committee, ensure maximize resources, operating in } \\
\text { good faith, modeling collaboration, law, professional, }\end{array}$ \\
\hline 7.How is Policy 2525 carried out in the classroom? & $\begin{array}{l}\text { Policy-10.1-10.6 } \\
\text { Early childhood teachers-not sure } \\
\text { Local adminstrators-different degrees in classroom, experience of teacher varies, ratios } \\
\text { maintained, fully inclusive, IEPS met, parents included, transition to K, creative } \\
\text { curriculum guide instruction and planning } \\
\text { County administrator-every class prek, attend in own attendance area, divide HS and } \\
\text { special needs evenly, intentional teaching, no differentiation, how to structure } \\
\text { classroom, incorporate needs, certification of teachers, outside equipment, funding, } \\
\text { personnel } \\
\text { State administrator-law } 50 \% \text { collaborative, play based, no worksheets, no content in } \\
\text { isolation, no direct instruction, health and safety, enrollment is voluntary attendance is } \\
\text { mandatory }\end{array}$ \\
\hline
\end{tabular}




\begin{tabular}{|c|c|}
\hline $\begin{array}{l}\text { 8. What is the biggest benefit of universal preschool policy (Policy } \\
\text { 2525)? Describe. }\end{array}$ & $\begin{array}{l}\text { Policy-9.1, } 9.2,11.1,12.1-12.5 \\
\text { Early childhood teachers-social interaction, negotiating skills, family friendly, } \\
\text { evaluation piece, free prek, get all kids in that need and want it, earlier children get to } \\
\text { learn, hands on experience } \\
\text { Local administrators-go to for rules, all children have opportunity to attend quality } \\
\text { preschool, equality in education } \\
\text { County administrator-ensure child development, principals understanding of } \\
\text { preschool, provide training with collaborative, opportunity to bring into education, } \\
\text { especially special needs, work with children } \\
\text { State administrator-clear message to citizens re: quality ec settings, experiences for } \\
\text { children, annual assessment of program, good curriculum, service to children-all }\end{array}$ \\
\hline $\begin{array}{l}\text { 9.What is the biggest challenge of universal preschool policy (Policy } \\
\text { 2525)? }\end{array}$ & $\begin{array}{l}\text { Policy-4.1, } 6.1-6.4,7.1,8.2,13.1,16.1-16.4 \text {, } \\
\text { Early childhood teachers-proper implementation, policy makers not teachers, staff } \\
\text { child ratio too high, administration to understand-child development, parents not } \\
\text { wanting children to go too early } \\
\text { Local administrators-follow federal guidelines, only monitor with suggestions, not } \\
\text { enough funding for policy, every interested child has placement, hiring, training } \\
\text { County administrator-providing teacher total support, blend children, working with HS } \\
\text { to accept children with higher income, appropriate rooms and settings, teacher } \\
\text { certification, mentality } \\
\text { State administrator-equity of service, quality, truly following policy, healthy and safe } \\
\text { environments, collaboration, turf issues, policy looks like HS standards, collaboration, } \\
\text { relationships difficult, funding }\end{array}$ \\
\hline $\begin{array}{l}\text { 10.How does Policy } 2525 \text { immediately benefit early childhood } \\
\text { education? }\end{array}$ & $\begin{array}{l}\text { Policy-2.1.1, 2.1.4, 2.1.5, } 2.1 .8,2.1 .9,2.1 .14,2.1 .15,8.5,8.6,8.7,8.13,8.17,8.18 \text {, } \\
8.19,8.20,8.21,8.22,8.23,8.25,8.26,8.28,10.1-10.6,11.1,12.1-12.5 \\
\text { Early childhood teachers-opens door for more children, developmentally appropriate, } \\
\text { gets children prepared for school, place to go, social aspects-basic concepts, } \\
\text { opportunities for employment, more qualified ec workforce, unified curriculum, } \\
\text { quality framework } \\
\text { Local adminstrators-sets standard, ratios maintained, fully inclusive, IEPS met, parents } \\
\text { included, transition to K, creative curriculum guide instruction and planning } \\
\text { County administrator-earlier education, social play, enriched environment, } \\
\text { conversations, early learning, do not start off behind, readiness, routines, accountable } \\
\text { for children's progress, goals and objectives } \\
\text { State administrator-parents resources to why important to child, prek program relevant, } \\
\text { concrete, whole body, foundation, children provided service might not have, life long } \\
\text { learners, parents see importance of education }\end{array}$ \\
\hline
\end{tabular}




\begin{tabular}{|c|c|}
\hline 11.What are the long term implications of Policy 2525 for children? & $\begin{array}{l}\text { Policy-2.1.1, 2.1.4, 2.1.5, 2.1.8, 2.1.9, 2.1.14, 2.1.15, 8.5, 8.6, 8.7, 8.13, 8.17, 8.18, } \\
8.19,8.20,8.21,8.22,8.23,8.25,8.26,8.28,10.1-10.6,11.1,12.1-12.5 \\
\text { Early childhood teachers- better prepared for K, focus on social, taught basic concepts } \\
\text { Local administrators-earlier head start, less drop out rate, developmentally appropriate, } \\
\text { banning worksheets and standardized tests, policy protects integrity of preschool } \\
\text { County administrator-learn through play, build self esteem, blend special needs } \\
\text { children, } 21^{\text {st }} \text { century skills, teaching to think and solve problems, getting kids ready } \\
\text { for school, social } \\
\text { State administrator-life long skills, starting children off on right foot, disposition to } \\
\text { learning, document stays alive with best interest of children, less children in Tier } 2 / 3 \\
\text { instruction and IEPS, head start they need }\end{array}$ \\
\hline $\begin{array}{l}\text { 12.If revising universal preschool policy (Policy 2525), what } \\
\text { suggestions would you have? }\end{array}$ & $\begin{array}{l}\text { Policy-2.1.11, } 6.1-6.14,6.7,7.1-7.7,8.26,10.1-10.6,13.1 \\
\text { Early childhood teachers-staff child ratio, transportation, educate parents, professional } \\
\text { development courses, easier access to certification, collaborative funding, continual } \\
\text { teacher training } \\
\text { Local adminstrators-rethink } 50 / 50 \text { collaboration-collaboration encouraged but not } \\
\text { required by \%, mesh regulations with personnel regulations, portfolio expectations } \\
\\
\text { County administrator-relationships, agencies not talking to one another, uniform } \\
\text { contracts, child care centers-lesser rate, what must child care center look like to } \\
\text { partner, staff child ratio, concerned with child care center collaboration, funding } \\
\text { support, } 4 \text { day full day plan } \\
\text { State administrator-staff child ratio, ECERS-take to next level, strengthen } \\
\text { collaboration, emphasis on curriculum and assessment piece, evaluate program, need } \\
\text { for developmentally appropriate practice, teacher certification-educational background } \\
\text { in ec, every teacher hold prek certification with ongoing follow-up, retraining }\end{array}$ \\
\hline
\end{tabular}




\section{APPENDIX C}

\section{Open-Coded Matrix}

\begin{tabular}{|c|c|c|c|c|c|c|}
\hline & $\begin{array}{l}\text { What is your } \\
\text { position or title in } \\
\text { the school system? }\end{array}$ & $\begin{array}{l}\text { How does your } \\
\text { position relate to } \\
\text { universal } \\
\text { preschool policy } \\
\text { (Policy 2525)? }\end{array}$ & $\begin{array}{l}\text { In job description, is } \\
\text { your involvement } \\
\text { with universal } \\
\text { preschool policy } \\
\text { (Policy 2525) } \\
\text { mentioned? Please } \\
\text { provide the exact } \\
\text { wording. }\end{array}$ & $\begin{array}{l}\text { What are the } \\
\text { goals of universal } \\
\text { preschool policy } \\
\text { (Policy 2525)? }\end{array}$ & $\begin{array}{l}\text { What is your role in } \\
\text { implementation of } \\
\text { universal preschool } \\
\text { (Policy 2525)? }\end{array}$ & $\begin{array}{l}\text { How is universal preschool } \\
\text { (Policy 2525) being } \\
\text { implemented in your } \\
\text { department/system/school? }\end{array}$ \\
\hline Jackson & $\begin{array}{l}\text { State } \\
\text { administrator }\end{array}$ & & & Every child & $\begin{array}{l}\text { Equitable program for } \\
\text { all 3-4 year olds, } \\
\text { available to everyone, } \\
\text { quality, research } \\
\text { based practices, } \\
\text { meals, health, safety, } \\
\text { experiential learning, } \\
\text { developmentally } \\
\text { relevant }\end{array}$ & \\
\hline Hilton & $\begin{array}{l}\text { State } \\
\text { administrator }\end{array}$ & $\begin{array}{l}\text { Section 16-every } \\
\text { class evaluated for } \\
\text { quality, train } \\
\text { trainers }\end{array}$ & & & & $\begin{array}{l}\text { Prek steering committee, } \\
\text { ensure maximize resources, } \\
\text { operating in good faith, } \\
\text { modeling collaboration, law, } \\
\text { professional }\end{array}$ \\
\hline Reagan & $\begin{array}{l}\text { State } \\
\text { administrator }\end{array}$ & $\begin{array}{l}\text { Training on } \\
\text { curriculum and } \\
\text { assessment } \\
\text { (creative } \\
\text { curriculum) }\end{array}$ & & $\begin{array}{l}\text { Erase funding } \\
\text { stream from } \\
\text { children, } \\
\text { inclusive settings, } \\
\text { just children }\end{array}$ & $\begin{array}{l}\text { Curriculum and } \\
\text { assessment, steering } \\
\text { committee }\end{array}$ & $\begin{array}{l}\text { Assigned different roles from } \\
\text { policy-health and safety, } \\
\text { board of ed understands } \\
\text { policy to be implemented }\end{array}$ \\
\hline
\end{tabular}




\begin{tabular}{|c|c|c|c|c|c|c|}
\hline Jennifer & $\begin{array}{l}\text { County } \\
\text { administrator }\end{array}$ & $\begin{array}{l}\text { Responsible for } \\
\text { following } \\
\text { regulations-Policy } \\
2525 / \text { HS blend }\end{array}$ & Implement policy & $\begin{array}{l}\text { Developmentally } \\
\text { appropriate } \\
\text { program, } \\
\text { required to } \\
\text { partner with } \\
\text { agencies, } \\
\text { continuity, same } \\
\text { experiences }\end{array}$ & $\begin{array}{l}\text { Oversee prek plan, } \\
\text { working with } \\
\text { partners, contracts } \\
\text { with child care } \\
\text { centers }\end{array}$ & $\begin{array}{l}\text { HS standards and partnering } \\
\text { in prek }\end{array}$ \\
\hline Marie & teacher & $\begin{array}{l}\text { Lead teacher in } \\
\text { newly formed } \\
\text { classroom }\end{array}$ & Do not know & $\begin{array}{l}\text { Every } 4 \text { yr old } \\
\text { living in WV, full } \\
\text { inclusion, } \\
\text { regulations in } \\
\text { place, } \\
\text { professional } \\
\text { development for } \\
\text { child care } \\
\text { providers }\end{array}$ & $\begin{array}{l}\text { Initially county } \\
\text { committee, PIECES } \\
\text { advisory council, } \\
\text { provider of preschool } \\
\text { services }\end{array}$ & $\begin{array}{l}2 \text { classrooms, smaller size, } \\
\text { work collaboratively because } \\
\text { higher special needs, co } \\
\text { teaching }\end{array}$ \\
\hline Stephanie & Principals & $\begin{array}{l}\text { Contracted } \\
\text { specialist }\end{array}$ & $\begin{array}{l}\text { Training and } \\
\text { monitoring }\end{array}$ & $\begin{array}{l}\text { Every } 4 \text { year old } \\
\text { will have access } \\
\text { to free and } \\
\text { appropriate } \\
\text { preschool }\end{array}$ & $\begin{array}{l}\text { Curriculum and } \\
\text { assessment, ECERS, } \\
\text { file reviews, set goals } \\
\text { with teachers }\end{array}$ & $\begin{array}{l}\text { Every } 4 \text { year old not getting } \\
\text { same service, levels of } \\
\text { implementation different }\end{array}$ \\
\hline Leslie & $\begin{array}{l}\text { County } \\
\text { administrator }\end{array}$ & $\begin{array}{l}\text { Responsible for } \\
\text { implementation }\end{array}$ & I do not know & $\begin{array}{l}\text { Provide seamless } \\
\text { quality care }\end{array}$ & Write plan & Just me \\
\hline Beth & Principal & $\begin{array}{l}\text { Remain current on } \\
\text { policies and } \\
\text { procedures, assist } \\
\text { teacher in } \\
\text { following policy }\end{array}$ & I do not know & $\begin{array}{l}\text { Fully inclusive } \\
\text { classrooms, all } \\
\text { preschools } \\
\text { around state } \\
\text { follow same } \\
\text { guidelines }\end{array}$ & $\begin{array}{l}\text { County implemented } \\
\text { policy, administered } \\
\text { ECERS, wrote } \\
\text { improvement plans, } \\
\text { provided supplies, } \\
\text { monitored attendance, } \\
\text { write plan, ensured } \\
\text { ratio, provided staff } \\
\text { development, } \\
\text { monitored use of } \\
\text { Creative Curriculum, } \\
\text { monitored } \\
\text { observations, bus } \\
\text { safety tools, } \\
\text { monitored } \\
\text { registration and }\end{array}$ & $\begin{array}{l}\text { Strive to implement policy to } \\
\text { fullest potential, all classes } \\
\text { fully inclusive, } 23 \text { w/in class, } \\
8 \text { child care collaborative, } \\
\text { ECERS used as resource for } \\
\text { change, Sp Ed/county helps } \\
\text { funds materials, equipment, } \\
\text { environment }\end{array}$ \\
\hline
\end{tabular}




\begin{tabular}{|c|c|c|c|c|c|c|}
\hline & & & & & $\begin{array}{l}\text { documents, ensured } \\
\text { transition }\end{array}$ & \\
\hline Bethany & Teacher & $\begin{array}{l}\text { Care and educ 3-5 } \\
\text { yr some w/spec } \\
\text { needs, HS, prek- } \\
\text { autistic, } \\
\text { behavioral, } \\
\text { implement } \\
\text { creative } \\
\text { curriculum }\end{array}$ & $\begin{array}{l}1^{\text {st }} \text { yr in BOE, tchr } \\
\text { in North Central } \\
\text { Comm Action }\end{array}$ & $\begin{array}{l}\text { Developmentally } \\
\text { appropriate } \\
\text { education for all } \\
3-5 \text { and all } \\
\text { abilities, }\end{array}$ & Dictated & $\begin{array}{l}\text { Principals scared, need more } \\
\text { training, }\end{array}$ \\
\hline Lindsay & teacher & $\begin{array}{l}\text { Collaborative } \\
\text { setting-5 days }\end{array}$ & Not sure & $\begin{array}{l}\text { Early learning } \\
\text { experiences, } \\
\text { emergent } \\
\text { literacy, } 3 \text { yr olds } \\
\text { identified w/sp } \\
\text { needs }\end{array}$ & $\begin{array}{l}\text { Learning facilitator, } \\
\text { not limit their } \\
\text { learning }\end{array}$ & $\begin{array}{l}\text { 9-3 school day, daycare 3-5, } \\
\text { 5days/week, state standards, } \\
\text { environmental print, } \\
\text { facilitator }\end{array}$ \\
\hline Jeff & $\begin{array}{l}\text { County } \\
\text { administrator }\end{array}$ & $\begin{array}{l}\text { Establish policy, } \\
\text { contract with } \\
\text { vendors/HS }\end{array}$ & No & $\begin{array}{l}\text { Accommodate } \\
\text { space, involve } \\
\text { child care/HS, } \\
50 / 50\end{array}$ & $\begin{array}{l}\text { Implement policy, } \\
\text { adapt policy, direct } \\
\text { policy }\end{array}$ & $\begin{array}{l}\text { Law, negotiate contracts, seek } \\
\text { approval, pay, funding }\end{array}$ \\
\hline Dave & State & Write policy & No & $\begin{array}{l}\text { Comprehensive } \\
\text { program }\end{array}$ & Write policy & \\
\hline
\end{tabular}




\begin{tabular}{|c|c|c|c|c|c|c|}
\hline & $\begin{array}{l}\text { How is Policy } \\
2525 \text { carried out } \\
\text { in the classroom? }\end{array}$ & $\begin{array}{l}\text { What is the } \\
\text { biggest benefit of } \\
\text { universal } \\
\text { preschool policy } \\
\text { (Policy 2525)? } \\
\text { Describe. }\end{array}$ & $\begin{array}{l}\text { What is the biggest } \\
\text { challenge of } \\
\text { universal preschool } \\
\text { policy (Policy } \\
2525) ?\end{array}$ & $\begin{array}{l}\text { How does Policy } \\
2525 \\
\text { immediately } \\
\text { benefit early } \\
\text { childhood } \\
\text { education? }\end{array}$ & $\begin{array}{l}\text { What are the long } \\
\text { term implications of } \\
\text { Policy } 2525 \text { for } \\
\text { children? }\end{array}$ & $\begin{array}{l}\text { If revising universal preschool } \\
\text { policy (Policy 2525), what } \\
\text { suggestions would you have? }\end{array}$ \\
\hline Jackson-state & & $\begin{array}{l}\text { Finally getting } \\
\text { clear message to } \\
\text { average citizen re: } \\
\text { quality ec settings, } \\
\text { experiences for } \\
\text { every child }\end{array}$ & $\begin{array}{l}\text { Equity of service, } \\
\text { quality, truly } \\
\text { following policy, } \\
\text { healthy and safe } \\
\text { environments }\end{array}$ & $\begin{array}{l}\text { Parents resources } \\
\text { to why important } \\
\text { to child }\end{array}$ & $\begin{array}{l}\text { Life long skills, } \\
\text { starting children off } \\
\text { on right foot, } \\
\text { disposition to } \\
\text { learning }\end{array}$ & $\begin{array}{l}\text { Strengthen collaboration, } \\
\text { emphasis on curriculum \& } \\
\text { assessment piece, need for } \\
\text { developmentally appropriate } \\
\text { practice, evaluate program }\end{array}$ \\
\hline Hilton-state & $\begin{array}{l}\text { In law } 50 \% \\
\text { collaborative }\end{array}$ & $\begin{array}{l}\text { Annual } \\
\text { assessment of } \\
\text { program, good } \\
\text { curriculum }\end{array}$ & $\begin{array}{l}\text { Collaboration, turf } \\
\text { issues, } \\
\text { LEA/HS/childcare }\end{array}$ & $\begin{array}{l}\text { Prek program } \\
\text { relavant, } \\
\text { concrete, whole } \\
\text { body, foundation }\end{array}$ & $\begin{array}{l}\text { Documents stays } \\
\text { alive with best } \\
\text { interest of children }\end{array}$ & $\begin{array}{l}\text { Teacher certification- } \\
\text { educational background in ec, } \\
\text { every teacher hold prek } \\
\text { certificate with ongoing } \\
\text { follow-up; retraining }\end{array}$ \\
\hline Reagan-state & $\begin{array}{l}\text { Play base, no } \\
\text { worksheets, no } \\
\text { content in } \\
\text { isolation, no free } \\
\text { for all, no direct } \\
\text { instruction, health } \\
\text { and safety, } \\
\text { enrollment is } \\
\text { voluntary } \\
\text { attendance is } \\
\text { mandatory }\end{array}$ & $\begin{array}{l}\text { Service to } \\
\text { children, children } \\
\text { with } \\
\text { disabilities/low } \\
\text { income were } \\
\text { served but middle } \\
\text { group being } \\
\text { served with } \\
\text { quality school }\end{array}$ & $\begin{array}{l}\text { Collaboration, } \\
\text { policy looks like } \\
\text { Head Start } \\
\text { standards, } \\
\text { relationships } \\
\text { difficult, funding }\end{array}$ & $\begin{array}{l}\text { Children } \\
\text { provided service } \\
\text { they might not } \\
\text { have, life long } \\
\text { learners, help } \\
\text { people } \\
\text { understand } \\
\text { importance of ec, } \\
\text { parents see } \\
\text { importance of } \\
\text { education }\end{array}$ & $\begin{array}{l}\text { Less children in Tier } \\
2 / 3 \text { instruction } \& \\
\text { IEPS, head start they } \\
\text { need, }\end{array}$ & $\begin{array}{l}\text { Smaller class, more than } 2 \\
\text { adults, ECERS: take to next } \\
\text { level }\end{array}$ \\
\hline Jennifer-county & $\begin{array}{l}\text { Every class prek, } \\
\text { attend in own } \\
\text { attendance area, } \\
\text { divide HS and } \\
\text { special needs } \\
\text { evenly }\end{array}$ & $\begin{array}{l}\text { Ensure child } \\
\text { development, } \\
\text { principals } \\
\text { understanding of } \\
\text { preschool }\end{array}$ & $\begin{array}{l}\text { Providing teacher } \\
\text { total support }\end{array}$ & $\begin{array}{l}\text { Enriched } \\
\text { environment, } \\
\text { conversations, } \\
\text { early learning, do } \\
\text { not start off } \\
\text { behind, readiness, } \\
\text { routines }\end{array}$ & $\begin{array}{l}\text { Learn through play, } \\
\text { build self esteem, } \\
\text { blend special needs } \\
\text { children, }\end{array}$ & $\begin{array}{l}\text { Funding support, } 50 / 50 \\
\text { formula, } 4 \text { day full day plan }\end{array}$ \\
\hline
\end{tabular}




\begin{tabular}{|c|c|c|c|c|c|c|}
\hline Marie-teacher & $\begin{array}{l}\text { HS standards } \\
\text { already in place }\end{array}$ & $\begin{array}{l}\text { Social interaction, } \\
\text { negotiating skills, } \\
\text { family friendly, } \\
\text { evaluation piece } \\
\text { (ECERS) }\end{array}$ & $\begin{array}{l}\text { Proper } \\
\text { implementation, } \\
\text { policy makers not } \\
\text { teachers, staff child } \\
\text { ratio too high }\end{array}$ & $\begin{array}{l}\text { opportunities for } \\
\text { employment, } \\
\text { more qualified } \\
\text { work force for ec, } \\
\text { unified } \\
\text { curriculum, } \\
\text { quality } \\
\text { framework }\end{array}$ & $\begin{array}{l}\text { Better prepared for } \\
\text { Kindergarten and } \\
\text { upper grades, focus } \\
\text { on social }\end{array}$ & $\begin{array}{l}\text { Lower staff child ratio, } \\
\text { professional development, } \\
\text { community partner, natural } \\
\text { progression for collaborative } \\
\text { model for day cares to join in }\end{array}$ \\
\hline $\begin{array}{l}\text { Stephanie- } \\
\text { principal }\end{array}$ & $\begin{array}{l}\text { Different degrees } \\
\text { in different } \\
\text { classrooms- } \\
\text { experience of } \\
\text { teacher, } \\
\text { administrative } \\
\text { support }\end{array}$ & Go to for rules & $\begin{array}{l}\text { Follow federal } \\
\text { guidelines, only } \\
\text { monitor/suggestions }\end{array}$ & Sets standard & $\begin{array}{l}\text { Earlier head start, less } \\
\text { drop out rate }\end{array}$ & $\begin{array}{l}\text { Mesh regulations with } \\
\text { personnel regulations, staff } \\
\text { child ratio, portfolio } \\
\text { expectations }\end{array}$ \\
\hline Leslie-county & $\begin{array}{l}\text { Intentional } \\
\text { teaching, no } \\
\text { differentiation }\end{array}$ & $\begin{array}{l}\text { Work with a } \\
\text { provide training } \\
\text { with collaborative }\end{array}$ & $\begin{array}{l}\text { Blend children, } \\
\text { working with HS to } \\
\text { accept children with } \\
\text { higher income }\end{array}$ & $\begin{array}{l}\text { Accountable for } \\
\text { children's } \\
\text { progress, goals } \\
\text { and objectives }\end{array}$ & $\begin{array}{l}\text { Hope makes } \\
\text { difference, } 21^{\text {st }} \\
\text { century skills, } \\
\text { teaching to think and } \\
\text { solve problems }\end{array}$ & $\begin{array}{l}\text { Staff child ratio, concerned } \\
\text { with collaboration with child } \\
\text { care centers }\end{array}$ \\
\hline Beth-principal & $\begin{array}{l}\text { Ratios maintained, } \\
\text { fully inclusive, } \\
\text { IEPS met, parents } \\
\text { included, } \\
\text { transition to K, } \\
\text { Creative } \\
\text { curriculum guide } \\
\text { instruction and } \\
\text { planning }\end{array}$ & $\begin{array}{l}\text { All children have } \\
\text { opportunity to } \\
\text { attend quality } \\
\text { preschool, equality } \\
\text { in education }\end{array}$ & $\begin{array}{l}\text { Not enough funding } \\
\text { (state/local) for } \\
\text { policy, by } 2012 \\
\text { every interested } \\
\text { child has a place- } \\
\text { creation of } \\
\text { classrooms, hiring, } \\
\text { training }\end{array}$ & $\begin{array}{l}\text { Ratios } \\
\text { maintained, fully } \\
\text { inclusive, IEPS } \\
\text { met, parents } \\
\text { included, } \\
\text { transition to K, } \\
\text { Creative } \\
\text { curriculum guid } \\
\text { instruction and } \\
\text { planning }\end{array}$ & $\begin{array}{l}\text { Eventually prek will } \\
\text { be what K was, } \\
\text { developmentally } \\
\text { appropriate } \\
\text { instruction; banning } \\
\text { worksheets, } \\
\text { standardized testing, } \\
\text { policy } 2525 \text { protects } \\
\text { the integrity of } \\
\text { preschool }\end{array}$ & $\begin{array}{l}\text { Rethink } 50 \% \text { collaboration } \\
\text { statement b/c many counties } \\
\text { do not have adequate } \\
\text { childcare options, } \\
\text { collaboration encouraged but } \\
\text { not required by } \%\end{array}$ \\
\hline $\begin{array}{l}\text { Bethany- } \\
\text { teacher }\end{array}$ & & $\begin{array}{l}\text { Free prek to } \\
\text { families that need } \\
\text { it, get all kids in } \\
\text { that need and want } \\
\text { it }\end{array}$ & $\begin{array}{l}\text { Administration to } \\
\text { understand, } \\
\text { understand child } \\
\text { development } \\
\text { background/ } \\
\text { developmentally } \\
\text { appropriate }\end{array}$ & $\begin{array}{l}\text { Opens door for } \\
\text { more children, } \\
\text { developmentally } \\
\text { appropriate, gets } \\
\text { children prepared } \\
\text { for school }\end{array}$ & $\begin{array}{l}\text { If implemented the } \\
\text { way it should be }\end{array}$ & $\begin{array}{l}\text { Staff child ratio, } \\
\text { transportation w/older } \\
\text { children, separate prek from } \\
\text { school site to designed for } \\
\text { prek, centered around abilities } \\
\text { of children }\end{array}$ \\
\hline
\end{tabular}




\begin{tabular}{|c|c|c|c|c|c|c|}
\hline Lindsay-teacher & Not sure not seen & $\begin{array}{l}\text { Earlier children } \\
\text { get to learn, hands } \\
\text { on experience, } \\
\text { open ended ?s, } \\
\text { developmental } \\
\text { domains, build } \\
\text { upon experiences, } \\
\text { creative } \\
\text { curriculum good } \\
\text { tool for policy }\end{array}$ & $\begin{array}{l}\text { Parents not wanting } \\
\text { to let go of children } \\
\text { early, how to know } \\
\text { about ec }\end{array}$ & $\begin{array}{l}\text { Have a place to } \\
\text { go, social aspect- } \\
\text { basic concepts }\end{array}$ & $\begin{array}{l}\text { Taught basic } \\
\text { concepts, gap } \\
\text { between prek and } \\
\text { children that stay } \\
\text { home }\end{array}$ & $\begin{array}{l}\text { Educate parents (policy, ec, } \\
\text { population), professional } \\
\text { development courses, staff } \\
\text { child ratios, easier access to } \\
\text { certification, public school } \\
\text { has more resources, } \\
\text { collaborative funding, } \\
\text { continual teacher training, } \\
\text { ECERS too picky }\end{array}$ \\
\hline Jeff-county & $\begin{array}{l}\text { How to structure } \\
\text { classroom, } \\
\text { incorporate needs, } \\
\text { certification of } \\
\text { teachers, outside } \\
\text { equipment, } \\
\text { funding, personnel } \\
\end{array}$ & $\begin{array}{l}\text { Opportunity to } \\
\text { bring into educ, } \\
\text { especially special } \\
\text { needs, work with } \\
\text { children }\end{array}$ & $\begin{array}{l}\text { Appropriate rooms } \\
\text { and settings, teacher } \\
\text { certification, } \\
\text { mentality }\end{array}$ & $\begin{array}{l}\text { Earlier education, } \\
\text { social play }\end{array}$ & $\begin{array}{l}\text { Getting kids ready for } \\
\text { school, social }\end{array}$ & $\begin{array}{l}\text { 1.entities fighting- } \\
\text { relationship, 2.agencies not } \\
\text { talking to one another, } \\
\text { 3.uniform contracts, 4.child } \\
\text { care-lesser rate, 5.child care } \\
\text { centers-how come, what for, } \\
\text { must do this }\end{array}$ \\
\hline Dave & & $\begin{array}{l}\text { "Quality" } \\
\text { Safety/health, } \\
\text { curriculum, } \\
\text { student teacher } \\
\text { ratios, class size, } \\
\text { standards for } \\
\text { teachers }\end{array}$ & $\begin{array}{l}\text { People to } \\
\text { understand } \\
\text { importance of ec, } \\
\text { growth of counties, } \\
\text { financial }\end{array}$ & Earlier education & $\begin{array}{l}\text { Fewer kids in special } \\
\text { education, fewer drop } \\
\text { outs, improved test } \\
\text { scores }\end{array}$ & $\begin{array}{l}\text { Funding at state level, quality, } \\
\text { uniformity }\end{array}$ \\
\hline
\end{tabular}




\section{APPENDIX D}

West Virginia Regional Education Service Agency map

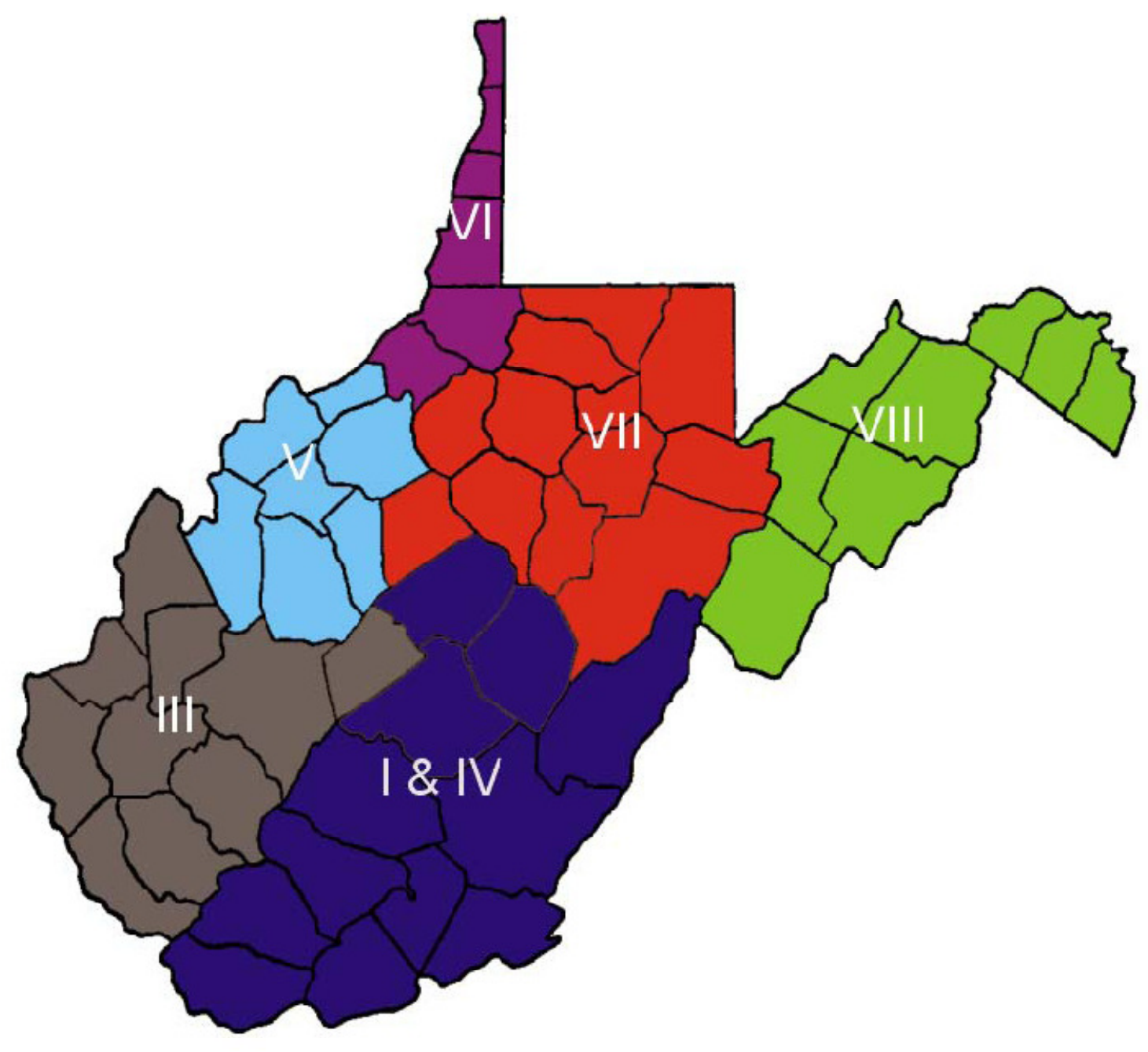

(West Virginia Department of Education) 
APPENDIX E

RESA Information

\begin{tabular}{|l|r|r|r|r|r|r|r|r|}
\hline & \multicolumn{1}{|c|}{$\begin{array}{l}\text { RESA } \\
\text { I }\end{array}$} & \multicolumn{1}{c|}{$\begin{array}{c}\text { RESA } \\
\text { II }\end{array}$} & \multicolumn{1}{c|}{$\begin{array}{c}\text { RESA } \\
\text { III }\end{array}$} & $\begin{array}{c}\text { RESA } \\
\text { IV }\end{array}$ & $\begin{array}{c}\text { RESA } \\
\text { V }\end{array}$ & \multicolumn{1}{c|}{$\begin{array}{c}\text { RESA } \\
\text { VI }\end{array}$} & $\begin{array}{c}\text { RESA } \\
\text { VII }\end{array}$ & $\begin{array}{c}\text { RESA } \\
\text { VIII }\end{array}$ \\
\hline Number of counties served & 6 & 6 & 4 & 6 & 8 & 5 & 12 & 8 \\
\hline Total enrollment of counties served & 33,005 & 38,533 & 43592 & 21,875 & 28,035 & 21,774 & 53,686 & 38,956 \\
\hline Square miles served & 2,921 & 2,567 & 2,117 & 4,369 & 27,00 & 966 & 5,152 & 3,490 \\
\hline
\end{tabular}

(A comprehensive study of the programs governance and administration of regional education service agencies, 2006)

John

$\mathrm{H}$.

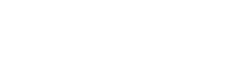

